MALDONADO, Francisco. “¿Se puede justificar la aplicación copulativa de penas y medidas de seguridad? Estado actual de las posiciones doctrinales que buscan dicho objetivo".

Polit. crim. Vol. 6, № 12 (Diciembre 2011), Art. 5, pp. 387 - 447. [http://www.politicacriminal.cl/Vol_06/n_12/Vol6N12A5.pdf]

\title{
¿Se puede justificar la aplicación copulativa de penas y medidas de seguridad? Estado actual de las posiciones doctrinales que buscan dicho objetivo.
}

\author{
Francisco Maldonado Fuentes \\ Doctor en Derecho \\ Subdirector Centro de Estudios de Derecho Penal de la Universidad de Talca \\ frmaldonado@utalca.cl
}

\begin{abstract}
Resumen
El artículo busca revisar los argumentos de justificación que se han propuesto para legitimar la aplicación copulativa de penas y medidas de seguridad sobre individuos considerados culpables de un delito y que además sean calificados como peligrosos. Para ello se abordan las corrientes que entienden que el solo hecho de que los modelos penales de influencia continental se estructuran de forma dualista ofrece una justificación suficiente para imponer una pena y una medida como también el planteamiento de quienes que entienden que para ello se requiere de una razón externa (fundada en variantes del interés general de prevención del delito) $\mathrm{y}$, finalmente, el de quienes postulan la necesidad de atribuir dicha peligrosidad al individuo.
\end{abstract}

\section{Palabras clave}

Medidas de seguridad, dualismo, imputables peligrosos, peligrosidad.

\begin{abstract}
The article seeks to review the justifying arguments proposed for legitimizing the copulative application of sentences and security measures on individuals deemed guilty of a criminal offense and that furthermore have been qualified as dangerous. For this, tendencies are addressed that understand that the mere fact that penal models of continental influence are structured in a dualist manner offers sufficient justification to impose a sentence and a measure; as well as the approach by those who understand that for this an external reason is required (based on variants in the general interest of crime prevention) and, finally, that of those who propose the need to attribute said dangerousness to the individual.
\end{abstract}

\section{Key words}

Safety measures, dualism, dangerous suspects subject to prosecution, dangerousness. 
MALDONADO, Francisco. “¿Se puede justificar la aplicación copulativa de penas y medidas de seguridad? Estado actual de las posiciones doctrinales

que buscan dicho objetivo".

\section{Introducción.}

En nuestro entorno cultural es paradigmática la aceptación de un esquema de intervención penal de carácter compuesto, sosteniéndose casi uniformemente que las reacciones penales son tanto las penas como las medidas de seguridad. ${ }^{1}$ Pero, además de ello, es relevante considerar que un sector importante de la doctrina (que sin dudas calificaríamos como mayoritario), como también buena parte de las legislaciones, acogen la idea de que es posible imponer de manera conjunta y copulativa ambas reacciones, esto es, una pena y una medida de Seguridad o Corrección, en aquellos casos en que además de la culpabilidad puede afirmarse la peligrosidad del infractor.

Con ello no nos referimos a los casos en que se acepta que ambas formas de reacción penal puedan cumplir funciones acorde a fórmulas vicariales o de intercambio (aceptadas, esta vez, de manera uniforme), sino a aquellos en que la imposición de la pena se complementa con una medida de seguridad a ser satisfecha en forma conjunta o adicional, agregándose por ello una cuota de aflictividad al contenido que propone dicha sanción (la pena) con base en la culpabilidad.

Los problemas que plantea esta concreción de efectos de carácter compuesto son múltiples. Entre ellos destaca la propia pretensión de imponer una duplicidad de reacciones a partir de un único hecho delictivo (bis in idem), ${ }^{2}$ el límite cuantitativo que propone la medida de la culpabilidad $^{3} \mathrm{y}$, fundamentalmente, la contradicción lógica que supone el tratar al mismo tiempo al individuo culpable como un ente peligroso. ${ }^{4}$

Estas observaciones han llevado a que en la actualidad se haya consolidado la idea de que la imposición conjunta de una pena y de una medida de seguridad requiere de una justificación adicional, esto es, una que vaya más allá de las bases que llevan a sustentar cada una de estas formas de reacción individualmente. En este sentido, el contenido de dicha justificación se orienta directamente a anular o superar las dificultades o contradicciones que provienen de la consideración conjunta de ambas reacciones (en especial, las antes reseñadas) o, lo que es igual (si bien más preciso), de la concurrencia conjunta de los presupuestos que sirven para justificarlas individualmente. Se trata por ello de líneas argumentales que se mueven en un nivel diverso y necesariamente complementario a la justificación autónoma de cada forma de reacción.

\footnotetext{
${ }^{1}$ CURY URZÚA, Enrique, Derecho Penal. Parte General, $7^{\mathrm{a}}$ Edición, Santiago: Ediciones Universidad Católica de Chile, 2007, pp. 60 y 693; ETCHEBERRY O., Alfredo, Derecho Penal. Parte General, $3^{\mathrm{a}}$ Edición, Santiago: Edit. Jurídica de Chile, 2004, p. 229; GARRIDO MONTT, Mario: Derecho Penal. Parte General, T.I., 4 Edición, Santiago: Edit. Jurídica de Chile, 2007, pp. 14 y ss.; y 79 y ss.; NOVOA MONREAL, Eduardo, Curso de Derecho Penal chileno, $3^{\text {a }}$ Edición, Santiago: Edit. Jurídica de Chile, 2005, T.I., pp. 24 y T.II., pp. 371 y ss.

${ }^{2}$ GARRIDO MONTT, Derecho Penal, cit. nota ${ }^{\circ} 1$, pp. 81 y ss.

${ }^{3}$ GARRIDO MONTT, Derecho Penal, cit. nota ${ }^{\circ} 1$, p. 335.

${ }^{4}$ GUZMAN DALBORA, José Luis, La pena y la extinción de la responsabilidad penal, Montevideo/Buenos Aires: Edit. BdeF, 2009, p. 95.
} 


\section{Polit. crim. Vol. 6, No 12 (Diciembre 2011), Art. 5, pp. 387 - 447. [http://www.politicacriminal.cl/Vol_06/n_12/Vol6N12A5.pdf]}

En cuanto a ello, y a pesar de que la mayoría de las opiniones acogen la idea de que es posible encontrar fuentes que justifiquen este proceder compuesto, no existe unidad de pareceres en torno a cuál es el contenido que habilita a sostener una justificación. En efecto, son variadas las fórmulas que han sido propuestas a dichos efectos, sin que ninguna de ellas pueda presumir de constituir doctrina dominante. ${ }^{5}$

Nuestro objetivo es pasar revista a estos planteamientos desde una perspectiva crítica a objeto de visualizar en base a su propio mérito los aciertos y dificultades que proponen como mecanismos de justificación. ${ }^{6}$ Para ello separaremos en tres los lineamientos gruesos que agrupan a las diversas formulaciones conocidas. En primer lugar, están quienes asumen que el marco de la justificación individual de pena y medida es suficiente para justificar una opción dualista. Otros siguen el camino de profundizar el contenido utilitarista que origina la consideración de las medidas de seguridad en el derecho penal, a partir de variantes de la tesis que considera que concurre en estos casos un interés preponderante en la prevención del delito. Finalmente, un tercer grupo se orienta a profundizar las razones posibles de encontrar en la propia individualidad de quien padece las medidas.

Antes de empezar quisiéramos llamar la atención sobre la permanente actualidad de esta temática. Es conocida su relevancia en nuestros tiempos, constituyendo uno de los temas de moda que han concitado una atención preferente y creciente en la última década. Pero a la vez se trata de uno de los ámbitos que tradicional e históricamente generan desacuerdo y que, desde dicha condición, han logrado permanentemente tensionar a los modelos de sistematización y legitimación de la intervención penal. ${ }^{7}$

\section{La suficiencia de la justificación individual.}

\subsection{La doctrina tradicional.}

\subsubsection{Fórmula propuesta.}

Iniciamos esta revista con una descripción de las perspectivas más tradicionales de sustento de una reacción dualista como la reseñada. Y no tanto por su valor histórico, sino más bien por cuanto pareciera en buena medida aportar una base común a parte de las orientaciones

\footnotetext{
${ }^{5}$ Sus diferencias también se reflejan en el campo de las consecuencias que se entienden justificadas bajo cada perspectiva, tanto en lo referido a la extensión que puede llegar a alcanzar la intervención dualista (en particular, la que conlleva la medida de seguridad) como en la intensidad que puede llegar a representar para los derechos del condenado.

${ }^{6}$ Procuraremos de esta forma minimizar el riesgo de caer en la común tentación de observar un punto de vista determinado por el solo hecho de partir de supuestos (preliminares) diversos. De esta forma, el análisis no se desarrolla desde la óptica de una perspectiva de corte monista, predispuesta a favor de la imposibilidad de sumar los efectos de ambas formas de reacción o de compatibilizar sus respectivos presupuestos, sino en torno a la propia sustentabilidad interna de cada propuesta.

${ }^{7}$ GUZMAN DALBORA, La pena y la extinción, cit. nota $n^{\circ} 4$, p.87; ROBLES PLANAS, Ricardo, " $<$ Sexual Predators $>$. Estrategias y límites del derecho penal de a peligrosidad", InDret 4 (2007), p. 14. Ilustrativo resulta a este respecto el que VON LISZT indicara, ya en 1882, que "el combate enérgico contra la reincidencia es una de las tareas más importantes del presente" (el subrayado es nuestro), en La idea de fin en el Derecho Penal", ed. conjunta de Universidad Nacional Autónoma de México - Universidad de Valparaíso Chile, Edeval, 1994, pp. 115-6.
} 
MALDONADO, Francisco. “¿Se puede justificar la aplicación copulativa de penas y medidas de seguridad? Estado actual de las posiciones doctrinales

que buscan dicho objetivo".

que son sostenidas en la actualidad. De ahí que sean amplios los sectores que parecieran aun identificarse con estos contenidos, sea en forma total o parcial. ${ }^{8}$

Desde esta primera perspectiva se sostiene la posibilidad de recurrir copulativamente a penas y medidas de seguridad a partir de los propios argumentos que sostienen la aplicación de cada una de esas formas de reacción penal, entendiéndose que dicha base (individual) es suficiente para legitimar la aplicación de ambas consecuencias a partir de sus propios méritos individuales. En concreto, se postula que el Derecho penal buscaría alcanzar sus fines a través de dos subsistemas independientes, ${ }^{9}$ cada uno de los cuales gozaría de presupuestos y exigencias propias (y autónomas) que legitiman su uso. A partir de ello es su concurrencia en una situación determinada lo que habilitaría directamente al uso de cada una de las consecuencias mencionadas.

Bajo esta comprensión la pena y la medida de seguridad presentan diferencias en su contenido esencial, fundamentos, finalidades y límites propios, ámbitos (todos ellos) que las dotan de plena autonomía para reclamar su aplicación frente a un mismo supuesto de hecho. ${ }^{10}$ En concreto, la pena se fundamenta y limita por la culpabilidad, persigue preponderantemente fines de prevención general (o retributivos) siendo connatural y definitorio de sus contenidos la mera imposición (intencional) de un mal. Por su parte, la medida de seguridad encuentra su fundamento en la peligrosidad, persigue fines de prevención especial, se limita (y también justifica) por la proporcionalidad, ${ }^{11}$ conciliándose

\footnotetext{
${ }^{8}$ Una comprensión del modelo bajo características que en lo esencial coinciden con dicho esquema se puede apreciar actualmente en España en ANDRES DOMÍNGUEZ, Ana Cristina, "Habituales y Reincidentes", Revista de Derecho Penal n²2 (2007), pp. 84 y ss.; CHOCLAN MONTALVO, José Antonio, "Las medidas de seguridad y corrección en el nuevo Código penal", Poder Judicial, № $43-44$ (1996), pp. 94-5 y 99-104; ROMEO CASABONA, Carlos María, Peligrosidad y derecho penal preventivo, Barcelona: Edit. Bosch, 1986, pp. 64 a 68; SANCHEZ GARCÍA DE PAZ, Isabel, "Alternativas al Derecho Penal del enemigo desde el derecho Penal del ciudadano" en: CANCIO MELIÁ/GÓMEZ-JARA DIEZ (coords.): Derecho penal del enemigo. El discurso penal de la exclusión, Vol. 2, 2006, p. 891; y URRELA MORA, Asier, "Los principios informadores del derecho de medidas en el Código penal de 1995", $R D P C, 2^{\mathrm{a}}$ época, $\mathrm{N}^{\circ} 8$ (2001), pp. 167 a 194, pp. 183 y ss. En Chile lo propio acontece con FALCONE, Diego, "Una mirada crítica a la regulación de las medidas de seguridad en Chile", Revista de Derecho de la Pontificia Universidad Católica de Valparaíso XXIX (2007), pp. 237 a 245 y GUZMAN DALBORA, La pena y la extinción, cit. nota $n^{\circ}$ 4, pp. 92 y ss., quienes describen un modelo de similares características (si bien este último lo hace a partir de una comprensión de las medidas de seguridad como un instituto que no debe formar parte del Derecho penal).

${ }^{9}$ No se trata en todo caso de dos subsistemas definidos conforme a la comprensión tradicional o clásica, sino en atención a las diferentes funciones concretas que sirven pena y medida de seguridad, esto es, prevención general y prevención especial.

10 GARCÍA-PABLOS DE MOLINA, Antonio, Derecho Penal. Introducción, Madrid: Servicio de Publicaciones Facultad de Derecho, Universidad complutense de Madrid, pp. 197-8; SANZ MORAN, Angel, Las medidas de corrección y seguridad en el Derecho Penal, Valladolid: Edit., Lex Nova, 2003 (pp. 39-40); SILVA SÁNCHEZ, Jesus María, "La regulación de las medidas de seguridad (artículo 6)", en, DEL MISMO, El Nuevo Código Penal: Cinco cuestiones fundamentales, Barcelona: Edit. Bosch, 1997, pp. 28-30. En nuestro país Vid. ETCHEBERRY, Derecho Penal, cit. nota ${ }^{\circ}$ 1, p. 228; GARRIDO MONTT, Derecho Penal, cit. nota $\mathrm{n}^{\circ} 1$, p. 334; GUZMAN DALBORA, La pena y la extinción, cit. nota $\mathrm{n}^{\circ} 4$, pp. 79 y ss.; NOVOA MONREAL, Curso de Derecho Penal chileno, cit. nota ${ }^{\circ}$ 1, T.II., p. 375.

${ }^{11}$ Se encuentran superadas las perspectivas de corte netamente utilitarista, es decir, aquellas que entienden que la medida de seguridad se justifica exclusivamente por la efectiva satisfacción de los fines preventivo especiales a los que se dirige (GUZMAN DALBORA, La pena y la extinción, cit. nota $\mathrm{n}^{\circ} 4$, p.85). El
} 


\section{Polit. crim. Vol. 6, № 12 (Diciembre 2011), Art. 5, pp. 387 - 447. [http://www.politicacriminal.cl/Vol_06/n_12/Vol6N12A5.pdf]}

en sus contenidos aspectos de interés social (de prevención del delito) con finalidades que preferentemente son regidas por un ideal terapéutico, en cuanto orientadas a la recuperación (social) del individuo a través del tratamiento resocializador. ${ }^{12}$ En su caso, el objetivo de la mera neutralización (aceptado por algunos pocos) también encuentra soporte en la peligrosidad, la prevención especial $\mathrm{y}$, particularmente, a través de la justificación que concede la idea de proporcionalidad. ${ }^{13}$

Sobre estas bases se concibe al dualismo como una fórmula compuesta en la que la medida de seguridad viene a llenar los ámbitos que la pena no puede cubrir en términos preventivos a partir de su innegable asociación con el presupuesto de la culpabilidad y con los límites naturales y jurídicos que dicha base plantea. Se la acepta, entonces, como una especie de instituto de natural aplicación en casos de inimputabilidad (incluyendo la minoría de edad), semiimputabilidad, originalmente en hipótesis de peligrosidad (social y criminal) pre-

principal efecto de dicha consideración es que el diagnóstico o pronóstico de peligrosidad, aunque presente niveles determinantes, constituye un fundamento insuficiente para legitimar el recurso a las medidas de seguridad, siendo necesario, además, contar con un juicio de proporcionalidad favorable a dicha opción. A pesar de lo dicho es aun posible encontrar argumentaciones en tal sentido. Así sucede en el planteamiento de GRACIA MARTIN, Luis, "Culpabilidad y prevención en la moderna reforma penal española", $A P \mathrm{~N}^{\circ} 37$ (1993), pp. 547 y ss., p. 568 y en GRACIA MARTIN/BOLDOVA PASAMAR/ALASTUEY DOBON, Tratado de las consecuencias jurídicas del delito, Valencia: Edit. Tirant lo Blanch, 2006, p. 368; JAEN VALLEJO, Manuel, Sistema de consecuencias jurídicas del delito, nuevas perspectivas, Instituto de Investigaciones jurídicas, Universidad nacional Autónoma de Mexico, 2002, pp. 73-4; LANDROVE DIAZ, Gerardo, Las consecuencias jurídicas del delito, $5^{\circ}$ edición, Edit. Tecnos, 2002, pp. 114-5; ROMEO CASABONA, Peligrosidad y derecho penal preventivo, cit. nota $\mathrm{n}^{\circ}$ 8, p. 79.; SÁNCHEZ LAZARO, Fernando Guanarteme, "Un problema de peligrosidad post delictual. Reflexiones sobre las posibilidades y límites de la denominada custodia de seguridad", $R P \mathrm{~N}^{\circ} 17$ (2006), p. 147 nota 24 y pp. 152 y 157 y citas en nota 58; y en URRUELA MORA, "Los principios informadores", cit. nota n ${ }^{\circ}$ 8, p. 185.

${ }^{12}$ SILVA SÁNCHEZ, "La regulación de las medidas" 1997, cit. nota $\mathrm{n}^{\circ} 10$, pp. 27-9.

${ }^{13} \mathrm{~A}$ estas alturas está relativamente asentada la idea de que la proporcionalidad sustituye, al nivel de los presupuestos de legitimidad, a la función que la culpabilidad cumple en la pena como parámetro definitorio de lo tolerable. La mayoría de las citas a este respecto se remiten al análisis expuesto por ROXIN, Claus, "Franz von Liszt y la concepción político-criminal del Proyecto Alternativo", en, DEL MISMO, Fundamentos Político-criminales del Derecho Penal, Buenos Aires: Edit. Hammurabi, 2008, pp. 262 y ss. Entre ellas FRISCH, Wolfgang, "Las medidas de corrección y seguridad en el sistema de consecuencias jurídicas del derecho penal. Clasificación en las teorías de la pena, configuración material y exigencias del Estado de Derecho" (trad. Patricia Ziffer), In Dret 3(2007), p. 33; MIR PUIG, Santiago, Derecho Penal. Parte General. $7^{\mathrm{a}}$ Ed., Barcelona: Edit. Reppertor, 2005, p. 136; ZUGALDIA ESPINAR, José Miguel, Fundamentos de Derecho penal. Parte general, Valencia: Edit. Tirant Lo Blanch, 1993, p. 142 y en, DEL MISMO, Derecho penal. Parte general, Valencia: Edit. Tirant lo Blanch, 2004, p. 174. Asimismo SANZ MORAN, Las medidas de corrección, cit. nota $\mathrm{n}^{\circ} 10, \mathrm{p}$. 125, quien destaca que es en este juicio donde se hace patente la tensión dialéctica entre libertad individual y seguridad colectiva. Según Cerexo Mir constituye el fundamento ético de las medidas (CEREZO MIR, José, Curso de derecho Penal español. Parte General, Introducción. $6^{\text {a }}$ Ed., Edit. Tecnos, pp. 36 y ss.). En la misma línea JESCHECK, Hans Heinrich/WEIGEND, Thomas, Tratado de Derecho Penal. Parte general, (trad. Olmedo Cardenete ), $5^{\circ}$ ed. renovada y ampliada, Granada: Edit. Comares, 2002, pp. 91 y 867 y JORGE BARREIRO, Agustín, "Reflexiones sobre la compatibilidad de la regulación de las medidas de seguridad en el Código Penal de 1995 con las exigencias del Estado de Derecho", en: VV.AA., Homenaje al Profesor Dr. Gonzalo Rodríguez Mourullo, Navarra: edit., Thomson Civitas, 2005, pp. 565 a 586., p. 576, ROXIN, Claus, Derecho Penal. Parte General. Tomo I. Fundamentos. La estructura de la Teoría del delito. Trad. Luzón-Peña, D.M., Diaz y García Conlledo, M., De Vicente Remesal, J. Madrid: Edit. Civitas, 1997, pp. 105-6, URRUELA MORA, "Los principios informadores", cit. nota $\mathrm{n}^{\circ}$ 8, p. 183 y antes en 180, nota 37. Oo. (en Chile) en GUZMAN DALBORA, La pena y la extinción, cit. nota $n^{\circ} 4$, pp. 86 y 90 y ss. 
MALDONADO, Francisco. “¿Se puede justificar la aplicación copulativa de penas y medidas de seguridad? Estado actual de las posiciones doctrinales

que buscan dicho objetivo".

delictivas (o, mas bien, no-delictivas) y, por supuesto, para casos en que la habitualidad, la reiteración o la tendencia delictiva lleven a suponer la inutilidad e insuficiencia preventiva de la pena que debiere imponerse acorde a la culpabilidad. ${ }^{14}$

\subsubsection{Valoración crítica.}

El problema de base que propone esta comprensión emana del hecho que se funda en una desacertada descripción de la interacción que supone el dualismo penal. ${ }^{15}$ Dicha conceptualización no se corresponde con los caracteres que lo configuraron originalmente como fórmula de síntesis (con la que se supera la llamada lucha de escuelas) ${ }^{16}$ y tampoco resulta compatible con la comprensión actual del papel que cumple este conjunto complejo de herramientas en el sistema penal. ${ }^{17}$ Con ello, resulta también desacertada su potencialidad autónoma para llegar a justificar una reacción dual como la que ahora comentamos.

El punto está en que el solo hecho de que pena y medida formen parte de un mismo contexto de intervención (el sistema de intervención penal) y que se orienten al tratamiento de un mismo problema hace que inevitablemente detenten relaciones e incidencias recíprocas en una medida que no perite asumir que se trata efectivamente de ámbitos que puedan desarrollarse en forma autónoma o independiente. ${ }^{18}$

Por ejemplo basta constatar que si bien es efectivo que frente a un mismo supuesto de hecho se puede sustentar un juicio concreto de culpabilidad y un pronóstico de peligrosidad, ambas afirmaciones suponen una conceptualización del individuo que resulta difícil de compatibilizar. Mientras la culpabilidad constituye un juicio de valor que supone la aceptación (y afirmación) de un interlocutor válido, la peligrosidad presenta en este plano un carácter neutral en el que es del todo irrelevante la condición de persona o sujeto del individuo que es objeto de análisis. Se trata por ello de una afirmación que desconoce dicha condición y que por ello lleva a sustentar formas de relacionarse con el individuo asumido en su perspectiva biológica, ajeno a las consideraciones que emanan de nociones como la personalidad, la autonomía y la propia idea de responsabilidad. ${ }^{19}$ Se confirma si constatamos que la aceptación de ambos supuestos lleva a la aplicación de medidas de hetero-administración respecto de individuos a quienes se les reconoce autonomía, lo que supone una contradicción evidente que no es fácil de resolver.

Por otro lado, y en cuanto los límites que se desprenden de cada uno de estos supuestos son diversos, es claro que se pueden llegar a plantear ámbitos de intervención justificada de

\footnotetext{
${ }^{14}$ ETCHEBERRY, Derecho Penal, cit. nota n ${ }^{\circ}$ 1, pp. 226-7; GARRIDO MONTT, Derecho Penal, cit. nota $\mathrm{n}^{\circ} 1$, pp. 344-5.

${ }^{15}$ En el mismo sentido ZIFFER, Patricia, Medidas de seguridad. Pronósticos de peligrosidad en derecho penal, Buenos Aires: Edit. Hammurabi, 2008, p. 44, quien la califica más bien como una "simplificación".

${ }^{16}$ Sobre el concepto y su contenido Vid. QUINTERO OLIVARES, Gonzalo, Manual de Derecho Penal. Parte General, $3^{\text {a }}$ ed., Pamplona: Edit. Thomson / Aranzadi, 2002, p. 139

${ }^{17}$ ZIFFER, Medidas de seguridad, cit. nota $\mathrm{n}^{\circ} 15$, pp. 61-2.

${ }^{18}$ ETCHEBERRY, Derecho Penal, cit. nota ${ }^{\circ}$ 1, p. 229.

${ }^{19}$ GUZMAN DALBORA, La pena y la extinción, cit. nota ${ }^{\circ} 4$, p. 71-2.
} 


\section{Polit. crim. Vol. 6, No 12 (Diciembre 2011), Art. 5, pp. 387 - 447. [http://www.politicacriminal.cl/Vol_06/n_12/Vol6N12A5.pdf]}

diversa extensión o entidad, lo que propone una contradicción adicional. En concreto, se ofrece un escenario en el que uno de los contenidos limitativos concurrentes (aquél que pase a ubicarse en un estadio inferior) debe necesariamente reconocer vigencia al otro (aquél que propone una intervención mayor), lo que, por definición, implica que el primero carece a su respecto de reales virtudes limitativas. ${ }^{20}$

Estos ejemplos son solo muestras de que el dualismo, como mecanismo compuesto, no puede ser entendido como una fórmula donde las ópticas concurrentes operan de forma complementaria, sino que constituye más bien un punto de equilibrio de dos lógicas diversas y en buena medida contrapuestas. ${ }^{21}$ Se trata entonces de un modelo estructurado a partir de una relación de tensión, en la que ambas herramientas reconocen y promueven incidencias recíprocas, mostrando un desarrollo evolutivo que tiende por ello a la unificación. $^{22}$

Desde esta perspectiva la independencia que se postula para los sub-sistemas que lo componen no pasa de ser una lectura parcial y aparente de un sistema complejo de carácter compuesto que no es el fruto de una sumatoria de presupuestos y herramientas, sino de la interacción de ambos en pro de un objetivo común.

No es causal entonces que ambas formas de reaccionar hayan tendido a limitarse en forma recíproca en el curso del siglo XX, a partir de la tensión y contradicciones propias sus presupuestos y fórmulas de legitimación. Baste ver que la crítica a las medidas predelictivas logró con el tiempo motivar un consenso en torno a su rechazo y que éste se obtiene a partir de la consolidación del llamado principio del hecho, ${ }^{23}$ supuesto que es propio del Derecho penal de la pena y del todo ajeno a la natural (original) perspectiva que plantean las medidas de seguridad y su presupuesto centrado en la peligrosidad. ${ }^{24}$ Estas

\footnotetext{
${ }^{20}$ Nítidamente en ZIFFER, Medidas de seguridad, cit. nota $n^{\circ} 15$, p. 45: "si se admitiera la existencia de una segunda vía <alternativa $>$ que autorizara a hacer todo lo que la primera prohíbe, dicho principio quedaría en una declamación vacía".

21 Para FRISCH ("Las medidas de corrección", cit. nota $\mathrm{n}^{\circ} 13$, pp. 10, 13 y ss. y 36 y ss.) el camino tradicional presenta incongruencias en tanto se basan en contenidos que no dan cuenta de perspectivas de conjunto.

${ }^{22}$ De esta forma se explica por qué las discusiones que se suscitan hoy en día entre monismo y dualismo se reducen a la forma de como se concilian los espacios de interconexión de la pena y la medida (o, lo que es igual, de la culpabilidad y la peligrosidad) dentro del sistema. Al respecto SANZ MORAN, Las medidas de corrección, cit. nota $\mathrm{n}^{\circ}$ 10, p. 45; QUINTERO OLIVARES, Gonzalo, "Reflexiones sobre el monismo y el dualismo ante el proyecto de Código Penal", en: La reforma penal y penitenciaria, Santiago de Compostela, 1980, p. 131.

${ }^{23}$ CURY, Derecho Penal, cit. nota $n^{\circ}$ 1, p. 776; FALCONE, "Una mirada crítica", cit. nota $n^{\circ} 8$, p. 238; GARRIDO MONTT, Derecho Penal, cit. nota ${ }^{\circ}$ 1, p. 81; GUZMAN DALBORA, La pena y la extinción, cit. nota $\mathrm{n}^{\circ}$ 4, p.84; HORVITZ, María Inés/LÓPEZ, Julián, Derecho Procesal Penal chileno, Santiago: Edit. Jurídica de Chile, T.II, 2004, p. 555.

${ }^{24}$ La postdelictualidad constituye en la actualidad una exigencia que se ha impuesto en atención a que sólo el delito expresa el desvalor que orienta al uso de la prevención penal, siendo equivalente la función que al respecto cumple en torno a la pena y a la medida de seguridad (FRISCH, "Las medidas de corrección", cit. nota $\mathrm{n}^{\circ}$ 13, p. 29; SILVA SÁNCHEZ, Jesús María, “¿Medidas de seguridad sin imputación personal subjetiva? Consecuencias de la incidencia de anomalías y alteraciones psíquicas en niveles sistemáticos distintos de la imputabilidad”, en: LOPEZ BARJA DE QUIROGA/ZUGALDIA ESPINAR (Coord.), Dogmática y Ley penal. Libro Homenaje a Enrique Bacigalupo, Madrid-Barcelona: Edit. Marcial Pons, 2004,
} 
MALDONADO, Francisco. “ ¿Se puede justificar la aplicación copulativa de penas y medidas de seguridad? Estado actual de las posiciones doctrinales

que buscan dicho objetivo".

mismas bases entierran la pretensión de imponer consecuencias de carácter indeterminado. Por otro lado, es claro que la aceptación de la aplicación de medidas para semiimputables se ha basado en la vicarialidad, mecanismo en el que se renuncia a la lógica de los complementos en miras a optimizar el aporte que la pena y la medida proporcionan para servir objetivos de prevención especial. Finalmente, la pretensión de aplicación autónoma de medidas para inimputables e imputables peligrosos ha ido permanentemente acompañada de fuertes resistencias que, con matices, han logrado concitar (si bien de forma variable) espacios de consenso relativo. En efecto, el hecho de que ambos supuestos supongan una renuncia a contenidos limitativos que emanan de la culpabilidad ${ }^{25}$ ha motivado una permanente discusión acerca de la necesidad de considerar un complemento de legitimación, es decir, algo que va más allá del mérito que aporta la peligrosidad, la necesidad de la medida y la proporcionalidad en su utilización.

También conviene considerar que en este mismo periodo se ha producido un claro y paulatino acercamiento en los contenidos y presupuestos de ambas formas de reacción. ${ }^{26} \mathrm{~A}$ la ya mencionada exigencia de postdelictualidad que afecta al ámbito de las medidas de seguridad y el absoluto reconocimiento de que comparten con la pena un sustrato básico como sanciones (constituyen un mal para el individuo), ${ }^{27}$ se agrega el que se ha tendido a consolidar la orientación de la totalidad del modelo en torno a la prevención, lo que particularmente afecta a la caracterización que ha ido asumiendo el Derecho penal de la pena a partir de la consideración de un conjunto de elementos que en términos materiales se encuentran indiscutiblemente asociados a la emisión de un pronóstico de reiteración

pp. 889-90; STRATENWERTH, Günther, Derecho Penal. Parte General I. El hecho punible (trad. CANCIO MELIÁ/SANCINETTI), Navarra: Edit. Thomson Civitas, 2005, p. 46). Este fue precisamente el sentido que gatilló la incorporación de las medidas desde el derecho administrativo al ámbito de lo penal, motivación que si bien parece limitarse en una primera impresión a una cuestión de competencias, propone ventajas materiales que van más allá del plano formal. El propio Stoo (a quien se atribuye la fórmula dualista originaria) lo reconoce afirmando que el mayor aporte y la mayor novedad de su contribución radica en la posibilidad de gestión conjunta de la resolución pues ya era posible disponer su aplicación copulativa en base a la operatoria del sistema penal y administrativo policial (GARRIDO MONTT, Derecho Penal, cit. nota ${ }^{\circ}$ 1, p. 331). Lo central es entonces que sea un único juez (penal) el que adopte decisiones sobre ambas reacciones (SANZ MORAN, Las medidas de corrección, cit. nota $n^{\circ} 10$, p. 27). FALCONE ("Una mirada crítica", cit. nota ${ }^{\circ} 8$, p. 237), en un sentido similar, vincula la formula a la pretensión de unificar un estatuto de garantías para ambas reacciones. Conviene también destacar que el aporte del principio del hecho como evidencia de la peligrosidad es en la actualidad algo del todo secundario (RODRIGUEZ MOURULLO, Gonzalo, "Medidas de seguridad y Estado de derecho", en VV.AA.: Peligrosidad social y medidas de seguridad. La ley de peligrosidad y rehabilitación social de 4 de Agosto de 1970, Colección de Estudios, Universidad de Valencia, 1974, p. 363; FRISCH, "Las medidas de corrección", cit. nota n 13, p. 14; SILVA SÁNCHEZ, "La regulación", cit. nota n ${ }^{\circ}$ 10, p. 28. Conserva su relevancia en Chile FALCONE ("Una mirada crítica", cit. nota $n^{\circ} 8$, pp. 239-40). Oo. sobre el papel del hecho sobre la naturaleza de la medida en GUZMAN DALBORA, La pena y la extinción, cit. nota ${ }^{\circ} 4$, pp. 81 y 82.

${ }^{25}$ ZIFFER, Medidas de seguridad, cit. nota ${ }^{\circ} 15, \mathrm{p} .46$.

${ }^{26}$ FRISCH, "Las medidas de corrección", cit. nota $n^{\circ} 13$, p. 17. Destaca este autor que este empalidecimiento de las diferencias entre la pena y la medida de seguridad se debe fundamentalmente a la merma del carácter sancionatorio de la primera y a su acercamiento a fines preventivo especiales. En el mismo sentido ZIFFER, Medidas de seguridad, cit. nota ${ }^{\circ} 15$, p. 50 .

${ }^{27}$ Por todos, ZIFFER, Medidas de seguridad, cit. nota n ${ }^{\circ}$ 15, p. 47; Oo. en GUZMAN DALBORA, La pena y la extinción, cit. nota $\mathrm{n}^{\circ} 4$, p. 92 (si bien con matices en p. 93). 


\section{Polit. crim. Vol. 6, No 12 (Diciembre 2011), Art. 5, pp. 387 - 447. [http://www.politicacriminal.cl/Vol_06/n_12/Vol6N12A5.pdf]}

delictiva. ${ }^{28}$ Así lo demuestra la generalizada aceptación de fórmulas de condicionalidad de las condenas o de remisión de las mismas bajo regímenes de condicionalidad, la atribución de efectos atenuatorios frente a la ausencia de antecedentes penales, y la generalizada aceptación de que la pena privativa de libertad debe ejecutarse bajo regímenes de progresión (incluyendo una fase o etapa de libertad a prueba o condicional). ${ }^{29}$ También se evidencia en los hitos más relevantes que han caracterizado a la conceptualización dogmática de la teoría del delito en torno a fines, ${ }^{30}$ en el desarrollo de los fines de la pena y, en particular, en el que ha experimentado la exigencia sistemática de culpabilidad. ${ }^{31}$

Hay que tener presente que esta consolidación del ideario preventivo encuentra sus raíces en la propia configuración del modelo en torno a dos formas de reacción. Si bien la pena (y con ello la retribución) parece triunfar en la síntesis dualista, en cuanto se ubica como la reacción principal o fundamental del sistema penal (el recurso preferente o, si se prefiere, la regla general), no por ello detenta una posición de predominio sobre sus caracteres definitorios. El punto está en que el recurso preferente a la pena no trae aparejado el que la medida y sus presupuestos queden relegados a un papel secundario o auxiliar, sino todo lo contrario: su aplicación subsidiaria evidencia que el sistema se ha extendido formalmente a planos que la pena no puede alcanzar, reconociéndole un espacio de legitimidad propio, autónomo y, lo más importante, superior (o más amplio) respecto al que la pena puede cubrir y justificar. El sólo hecho de que se acepte llegar a calificarla como una reacción insuficiente (a efectos a habilitar al uso de medidas de seguridad) demuestra que sus contenidos propios (naturales u originales) no son los que definen los límites del modelo.

Con ello la sola asunción del dualismo implica también reconocer que la pena deja de ser el último recurso con que cuenta el Estado para el control de la criminalidad (la última ratio) como también reconocer que sus límites (en especial, la culpabilidad) no proponen una barrera infranqueable para la política criminal. ${ }^{32}$ Los límites del sistema pasan a ser determinados a partir de una óptica centrada en la necesidad preventiva, objetivo que por

\footnotetext{
${ }^{28}$ ZIFFER, Medidas de seguridad, cit. nota $\mathrm{n}^{\circ}$ 15, pp. 44. Así lo sostiene también, y categóricamente, GUZMAN DALBORA, La pena y la extinción, cit. nota $\mathrm{n}^{\circ} 4$, pp. 88 y ss., si bien desde una perspectiva crítica.

${ }^{29}$ ZIFFER, Medidas de seguridad, cit. nota ${ }^{\circ} 15$, pp. 57 y ss.

30 Paradigmático, ROXIN, Claus, Política criminal y sistema del derecho penal, trad. Muñoz Conde, Barcelona: Edit. Bosch., 1972, passim.

${ }^{31}$ Sobre la configuración de la culpabilidad en clave preventiva Vid. JAKOBS, "Culpabilidad y prevención" en, DEL MISMO, Estudios de derecho penal, Madrid: Edit. Civitas, 1997, pp. 73 y ss.; ROXIN, Claus, Culpabilidad y responsabilidad como categorías sistemáticas jurídico-penales, en, DEL MISMO, Culpabilidad y Prevención, Madrid: Edit. Reus, pp. 57 y ss.; OCTAVIO DE TOLEDO, Sobre el concepto de derecho penal. Madrid: Sección de publicaciones, Facultad de Derecho, Universidad de Madrid, 1981, p. 246. Sobre la configuración concreta de los presupuestos de la culpabilidad bajo las perspectivas de la prevención general negativa GIMBERNAT ORDEIG, Enrique, “¿Tiene un futuro la dogmática jurídico-penal?”, en, DEL MISMO, Estudios de Derecho Penal, Edit. Tecnos, 3 ed., 1990, pp. 140 a 161, pp. 146 y ss. y 157 a 161 y en "El sistema del derecho penal en la actualidad" en, DEL MISMO, Estudios de Derecho Penal, Madrid: Edit. Tecnos, 1990, pp. 175 y ss.

${ }^{32}$ En un sentido similar FALCONE ("Una mirada crítica", cit. nota $n^{\circ}$ 8, p. 236) quien destaca que "las medidas de seguridad constituyen verdaderamente última ratio”.
} 
MALDONADO, Francisco. “¿Se puede justificar la aplicación copulativa de penas y medidas de seguridad? Estado actual de las posiciones doctrinales

que buscan dicho objetivo".

ello pasa a regir (y desde esa posición, a incidir) la configuración de la totalidad del modelo. ${ }^{33}$

Ahora bien, detenidos en este punto hay dos cuestiones que son relevantes de destacar. La primera dice relación un antecedente que es de vital importancia para entender este fenómeno y sus consecuencias: la tendencia a la unificación no es en exclusiva el fruto de la necesidad de adoptar una decisión salomónica que incorpore ambas formas de reacción, sino que encuentra sus raíces en las propias debilidades que presenta la pena y la medida y sus respectivos presupuestos, los que, en buena medida, motivan la búsqueda de complementos. Así, y como indica Frisch, la pérdida de influencia que experimenta el modelo retributivo de la pena (que es el que concurre originalmente a configurar el modelo dualista y que lleva a potenciar los aspectos preventivos en la pena) encuentra sus razones esenciales en la pretensión de lograr plena coherencia con sus postulados constitutivos lo que favoreció y potenció una percepción crítica sobre el alcance de sus efectos. ${ }^{34}$

Otro tanto acontece con la óptica de intervención que plantea la medida de seguridad pues también fueron sus propias insuficiencias naturales las que originaron una dura crítica a su legitimidad. Las dudas sobre la asertividad del pronóstico de peligrosidad, la histórica presencia de abusos motivados en la afirmación de necesidades preventivo-especiales o en calificaciones parciales (emanadas de los intereses de determinados grupos sociales) y excesivas (impositivas de valores o formas de ser) de este presupuesto (la peligrosidad) pasan, a corto andar, a constituir muestras de los riesgos que se debían enfrentar en caso de acoger sus postulados y que resultaban intolerables en un Estado de Derecho. ${ }^{35}$ Es a partir de ello que se consolida la idea de exigir la satisfacción de principios como la legalidad, un estricto apego a la peligrosidad de delito diagnosticada y con ello a la necesidad de la medida de seguridad, la postdelictualidad, la jurisdiccionalidad $\mathrm{y}$, finalmente, la

\footnotetext{
${ }^{33}$ GUZMAN DALBORA, La pena y la extinción, cit. nota $n^{\circ}$ 4, p.73; HASSEMER, Winfried/MUÑOZ CONDE, Francisco, Introducción a la criminología y al derecho penal, Valencia: Edit. Tirant lo Blanch, 1989, p.166; MIR PUIG, Introducción a las Bases del Derecho Penal, $2^{\mathrm{a}}$ ed. reimpresión, MontevideoBuenos Aires :Edit. BdeF, 2003, p. 67; OCTAVIO DE TOLEDO, Sobre el concepto, cit. nota ${ }^{\circ}$ 31, p. 252. Así se explica que a pesar de la contundencia de las críticas esbozadas sobre la mecánica de justificación propuesta por el positivismo criminológico sea usual encontrar en la literatura (incluso contemporánea) referencias concretas a que las medidas de seguridad tiene por fin neutralizar la peligrosidad criminal del sujeto en tanto "ello resulta necesario" para el cumplimiento de los "fines de prevención (protección) social". ${ }^{34}$ Es un hecho que en el derecho penal clásico se ampliaban los contenidos del derecho penal de la culpabilidad en forma relativamente artificial para dar cabida a institutos y respuestas que son propias de un derecho penal de la peligrosidad, al no existir medidas de seguridad ni instancias propiamente orientadas a dichas perspectivas, dinámica que el pensamiento racionalista clásico pretendió (re)encausar, motivando con ello, indirectamente, las dimensiones que adquirió la arremetida del pensamiento positivista. Lo destaca claramente SILVA SÁNCHEZ, "La regulación", cit. nota n 10, p. 23; Asimismo, en Chile, NOVOA MONREAL, Curso de Derecho Penal, cit. nota n ${ }^{\circ}$, p. 372.

${ }^{35}$ Por todos, FRISCH, "Las medidas de corrección", cit. nota $n^{\circ} 13$, p. 10; LANDROVE DIAZ, Las consecuencias jurídicas, cit. nota $\mathrm{n}^{\circ} 11, \mathrm{p}$. 114. Originalmente ello no se percibió atendido que las medidas de seguridad fueron elaboradas bajo el prisma puramente utilitarista (propio del positivismo criminológico) donde no se discutió su fundamento ético-político, sus implicancias para el Estado de Derecho ni los problemas empíricos que ello propone.
} 


\section{Polit. crim. Vol. 6, № 12 (Diciembre 2011), Art. 5, pp. 387 - 447. [http://www.politicacriminal.cl/Vol_06/n_12/Vol6N12A5.pdf]}

proporcionalidad con el daño que se pretende precaver, exigencia esta última que pasa a cumplir un papel determinante en la aceptación de este tipo de intervención. ${ }^{36}$

La síntesis dualista fue por ello una fórmula conclusiva que, en buena parte, ofrece un alivio para estas tensiones, pero que a la vez motiva la necesidad de encontrar un punto de equilibrio en el aporte que ambas reacciones proponen para un objetivo común. Constituye un canal a través del cual se favorece una especie de formalización o explicitación de los déficits propios de cada mecanismo.

Lo segundo a considerar es que la radicación de los límites del sistema en torno a los objetivos de la prevención no decanta en una tendencia que lleve a proyectar una desaparición material del derecho penal de la pena o, si se prefiere, en una conceptualización que permita una virtual confusión de ambos aportes en un solo mecanismo. ${ }^{37}$ Pena y medida, en su configuración tradicional, siguen siendo consideradas necesarias en el mundo continental en cuanto se las concibe como herramientas que contribuyen en forma diversa a la satisfacción de un mismo y único objetivo, sin que ninguna de ellas pueda llegar a suplir el aporte que proporciona la otra a la globalidad del sistema. ${ }^{38}$ En concreto la doctrina ampliamente dominante rechaza la idea de que la medida

${ }^{36}$ Por todos, MUÑOZ CONDE, Francisco/GARCÍA ARAN, Mercedes: Derecho Penal. Parte General, $8^{\mathrm{a}}$ ed., Valencia: Edit. Tirant Lo Blanch, 2010, pp. 578 y ss.; ZUGALDÍA Et. Al, Derecho penal. Parte general, Valencia: Edit. Tirant lo Blanch, 2004, pp. 165 y ss. Puede verse un desarrollo monográfico sistematizado en GARCÍA ARAN, Mercedes, Fundamentos y aplicación de penas y medidas en el Código Penal de 1995, Pamplona: Edit. Aranzadi, 1997, pp. 128 y ss.; JORGE BARREIRO, "Reflexiones sobre la compatibilidad", cit. nota $\mathrm{n}^{\circ} 13,2005$, pp. 567 y ss.; SANZ MORAN, Las medidas de corrección, cit. nota ${ }^{\circ} 10$, pp. 109 y ss. y 157 y ss.; URRUELA MORA, "Los principios informadores", cit. nota $\mathrm{n}^{\circ}$ 8, pp. 168 y ss. En Chile FALCONE, "Una mirada crítica", cit. nota ${ }^{\circ}$ 8, pp. 245 a 247.

${ }^{37}$ La tendencia a la unificación debiese afectar esencialmente a la pena pues la radicación de los límites en los objetivos de la prevención deja la impresión de que para alcanzarlos bastaría con una reacción monista como la que ofrece la medida, cualquiera sea su denominación o etiqueta (QUINTERO OLIVARES, "Reflexiones sobre el monismo", cit. nota $\mathrm{n}^{\circ} 22$, p. 575). Sobre las razones de una eventual unificación vid., con detalle, ZIFFER, Medidas de seguridad, cit. nota 15, pp. 46 y ss. Dicho camino fue concreta y ampliamente explorado como efecto del dualismo. A mediados del siglo XX el debate se centró en la posibilidad de configurar un sistema de respuesta única capaz de combinar en sus propios contenidos el sentido de futuro que propició la escuela moderna y los principios asociados -en ese momento- a la retribución (sobre ello vid. BARBERO SANTOS, Marino, Marginación social y Derecho represivo, Barcelona: Bosch, 1980, pp. 5 y ss.). Los conceptos de "Terza scuola" o "Nueva defensa social", asociado a autores como GRAMATICA; ANTOLISEI (Scritti di diritto penale, 1955) o DELITALA (RIDPP: 1950) y al francés M. ANCEL $(A D P C P, 1956)$ o la férrea defensa de la "pena indeterminada" realizada por JIMENEZ DE ASUA (si bien en este caso dicho contenido obedece a una concreta extensión de las ideas de von Liszt) dieron contenido a dichas discusiones. Cada uno de estos esfuerzos fueron rechazados a poco andar por razones asociadas a su incompatibilidad con el Estado de Derecho (indeterminación de la reacción, discrecionalidad en el tratamiento, etc.). Sobre ello vid. GARCÍA PABLOS, Derecho Penal, cit. nota $\mathrm{n}^{\circ}$ 10, pp. 213-4; NOVOA MONREAL, Curso de Derecho Penal, cit. nota $\mathrm{n}^{\circ}$ 1, pp. 374 y ss.; OCTAVIO DE TOLEDO, 1981, cit. nota $n^{\circ}$ 31, p. 250; SANZ MORAN, Las medidas de corrección, cit. nota $\mathrm{n}^{\circ} 10$, pp. 34-5; SILVA SÁNCHEZ, "La regulación", cit. nota $\mathrm{n}^{\circ} 10$, p. 24.

${ }^{38}$ Para Silva Sánchez ello sucede esencialmente porque se trata de instrumentos que se mueven en planos diversos, abordando la pena una dimensión de sentido y la medida el campo de lo empírico. Buscan enfrentar casos diversos a pesar de que lo hacen para satisfacer un mismo objetivo: la necesidad de proteger a la sociedad frente a hechos penalmente antijurídicos. Se debe entonces conservar la individualidad de ambas para dotar al modelo las soluciones que requiere. SILVA SÁNCHEZ, "La regulación”, cit. nota n 10, p. 22 y 
MALDONADO, Francisco. “¿Se puede justificar la aplicación copulativa de penas y medidas de seguridad? Estado actual de las posiciones doctrinales

que buscan dicho objetivo".

pueda orientarse a fines de prevención general ${ }^{39}$ como también el que sea una respuesta capaz de transmitir contenidos de reproche o censura a partir de sus presupuestos. ${ }^{40}$ Por su parte es claro que la exigencia de culpabilidad limita las posibilidades de la pena frente a necesidades de prevención del delito cuya satisfacción es uniformemente considerada como una tarea propia del Derecho penal.

De esta forma el aporte autónomo de pena y medida encuentra un punto de conexión en torno a la satisfacción de objetivos de prevención especial, ${ }^{41}$ lo que ha motivado un amplio reconocimiento de funciones intercambiables en torno a dichos objetivos donde resultan equivalentes, principalmente en base a mecanismos vicariales. La prevención especial es, entonces, el motivo de conexión y a su vez la válvula que explica la interacción de ambas: el aporte que a este respecto produce la pena hace innecesario recurrir a la medida demandándose la aplicación de esta última ante las insuficiencias que a este respecto presenta la primera. ${ }^{42} 43$

32 y en 2004, p. 889; en el mismo sentido SANZ MORAN, Las medidas de corrección, cit. nota ${ }^{\circ}$ 10, p. 70. En nuestro país lo destaca claramente CURY, Derecho Penal, cit. nota n ${ }^{\circ} 1$, pp. 61 y 777.

${ }^{39}$ Así lo destacan FRISCH ("Las medidas de corrección", cit. nota n 13, p. 14) y SILVA SÁNCHEZ ("La regulación", cit. nota $\mathrm{n}^{\circ} 10$, p. 28); La misma uniformidad de pareceres reconoce que la media cumple de facto funciones preventivo generales, en el sentido que su aplicación (y ya su previsión) genera efectos concretos de carácter intimidatorio, y en su caso, de estabilización. Se trata de un efecto secundario, no intencional pero deseable (FRISCH, "Las medidas de corrección", cit. nota $n^{\circ} 13$, p. 14, Nota 65; SANZ MORAN, Las medidas de corrección, cit. nota n ${ }^{\circ} 10$, p. 76; SILVA SÁNCHEZ, "La regulación", cit. nota n 10, p. 28; ZIFFER, Medidas de seguridad, cit. nota ${ }^{\circ} 15$, p. 48). Este supuesto es a nuestro juicio discutible. Lo primero a considerar es que previo al asentamiento de la óptica retributiva el liberalismo clásico asumió una estrecha conexión (no intencionada) entre prevención general y peligrosidad personal a partir del nexo presente entre las ideas de alarma social y recaída en el delito, y que caracterizó el tratamiento de la reincidencia durante el siglo XIX. Sobre esas bases parece claro que se advertía que la perversidad, la animosidad contraria a derecho o la rebeldía inciden en los presupuestos y efectos atribuidos a la prevención general, contenidos que además conectaban directamente con los presupuestos de la culpabilidad. En la actualidad resulta discutible que las medidas impuestas para imputables se encuentren desconectadas de efectos tradicionalmente ligados a la prevención general. Se aprecia con claridad en la privación del permiso para conducir vehículos motorizados (ROXIN, Derecho Penal, cit. nota ${ }^{\circ} 13$, p. 104; DE FIGUEIREDO DIAS, Jorge, Direito Penal. Parte Geral, Coimbra Editora, 2004, p. 88), órdenes de alejamiento y en otras más gravosas a pesar de que se encuentran dirigidas a la mera contención (como la custodia de seguridad y sus variantes). Lo destaca ROXIN (idem) agregando que en su opinión se trata de consecuencias que "disuaden más que la propia pena" y, en Chile, PIÑA ROCHEFORT, Juan Ignacio, Derecho penal. Fundamentos de la responsabilidad, Santiago: Edit. AbeledoPerrot, 2010, pp. 132-3. Sobre esta problemática Vid. OCTAVIO DE TOLEDO, Sobre el concepto, cit. nota $\mathrm{n}^{\circ} 31$, pp. 113 y ss. GUZMAN DALBORA (La pena y la extinción, cit. nota $\mathrm{n}^{\circ} 4$, pp. 89 y ss.) reconoce la existencia de corrientes que quiebran la uniformidad que existe sobre este particular en la doctrina.

${ }^{40}$ GUZMAN DALBORA, La pena y la extinción, cit. nota $n^{\circ}$ 4, p. 85; ZIFFER, Medidas de seguridad, cit. nota $\mathrm{n}^{\circ} 15$, pp. 31,47 y ss. (con matices en p. 48 ).

${ }^{41}$ GUZMAN DALBORA (La pena y la extinción, cit. nota $\mathrm{n}^{\circ} 4, \mathrm{p} .95$ ) reconoce que dicha característica ya está presente en la configuración original del modelo, en referencia a von Liszt y a Stoo .

${ }^{42}$ La prioridad asignada a la pena no se basa en exclusiva en la necesidad de optimizar la intervención penal a través de efectos asociados a la culpabilidad y, en especial, de carácter preventivo general (ZIFFER, Medidas de seguridad, cit. nota $\mathrm{n}^{\circ} 15$, p. 38). Es más bien la sola afirmación de dicho supuesto lo que permite reclamar dicha preferencia en cuanto supone una exigencia de respeto y consideración a los espacios de desarrollo autónomos del individuo en un contexto constitucional regido por el respeto de las libertades individuales. La pena debe ser la reacción de aplicación preferente en cuanto constituye una herramienta naturalmente 


\section{Polít. crim. Vol. 6, No 12 (Diciembre 2011), Art. 5, pp. 387 - 447. [http://www.politicacriminal.cl/Vol_06/n_12/Vol6N12A5.pdf]}

Lo dicho también es sostenido por quienes entienden que ambas herramientas deben regirse por un mismo y único grupo de supuestos de justificación, rechazando con ello -entre otros efectos- que la actuación asegurativa pueda llegar a exceder la medida de la culpabilidad, ${ }^{44}$ lo que confirma que en nuestro entorno cultural constituye una cuestión del todo asentada. ${ }^{45}$

Todo ello explica por qué no es posible asumir tan sencillamente que los presupuestos de legitimación de pena y medida son suficientes para justificar la aplicación copulativa de

asociada a la interacción normativa a lo que se agrega el que, además, la medida conlleva un mayor contenido aflictivo (una mayor intromisión en las esferas de la autonomía individual). Vid. Al respecto ETCHEBERRY, Derecho Penal, cit. nota ${ }^{\circ} 1$, p. 226.

${ }^{43}$ Con ello es claro que la aplicación de las medidas de seguridad no se funda en exclusiva en una valoración de su propia necesidad aisladamente considerada, sino que se trata de un desarrollo que tiene en cuenta el aporte (preventivo especial) concreto que proporciona la imposición de la pena. Es la insuficiencia preventivo especial de la pena la que determina los espacios que se reconocen a la medida de seguridad.

${ }^{44}$ Esta corriente denominada nuevo monismo sostiene dicha conclusión a partir de la virtual asimilación que presentan en la actualidad los contenidos esenciales de ambas herramientas (constituyen por definición un mal para el individuo que es impuesto como reacción frente al delito y que persigue efectos preventivos) y de la convicción de que ninguna medida puede traducirse en una condición cuya aflictividad fuere superior a la que arriesga el condenado culpable, parámetro que es asumido como referente de lo normal (MUÑOZ CONDE, Derecho Penal y Control Social, reimpresión de la Segunda Edición, Colección Monografías Jurídicas $\mathrm{N}^{\circ}$ 98, Bogotá: Edit. Temis, 2004, p. 46). Se postula un dualismo de regla y un monismo de ejecución en el que ambas herramientas cuentan con sus propios espacios de incidencia (QUINTERO OLIVARES, "Reflexiones sobre el monismo", cit. nota $n^{\circ} 22$, p. 584; OCTAVIO DE TOLEDO, Sobre el concepto, cit. nota $\mathrm{n}^{\circ} 31,1984$, p. 255) o resultan (además) intercambiables en los espacios de interconexión (MUNOZ CONDE, Derecho Penal, cit. nota ${ }^{\circ}$ 44, p. 46; ZUGALDIA ESPINAR, Fundamentos de Derecho penal, cit. nota $\mathrm{n}^{\circ} 13$, p. 142), en miras a la mejor satisfacción de las necesidades de prevención. Se identifica con esta tesis a MUÑOZ CONDE (Derecho Penal, originalmente en -reimpresión-, cit. nota ${ }^{\circ}$ 44, pp. 45. y ss.; asimismo en "Monismo y dualismo en el derecho penal Español", Estudios Penales y Criminológicos VI (1983), Universidad Santiago de Compostela, pp. 215 y ss., pp. 215 y ss.), QUINTERO OLIVARES, "Reflexiones sobre el monismo", cit. nota ${ }^{\circ} 22$, pp. 571 y ss., OCTAVIO DE TOLEDO (Sobre el concepto, cit. nota $\mathrm{n}^{\circ} 31$ ) y ZUGALDÍA ESPINAR (Fundamentos de Derecho penal, cit. nota ${ }^{\circ} 13$, pp. 140 y ss.).

${ }^{45}$ En los modelos anglosajones se opta más bien por una dinámica mixta, constituyendo la culpabilidad el criterio que delimita los contornos del Derecho penal. Los contenidos preventivos asociados a casos de inculpabilidad son por ello excluidos del marco de referencia propio del Derecho penal, siendo en los demás casos integrados dentro de este sistema. Con ello la respuesta afrente a situaciones como las que ahora nos ocupan se materializa a través de un aumento en la aflictividad y extensión de la sanción procedente (esto es, de la pena). Se expresa en dinámicas que buscan simplemente anudar un efecto agravatorio especial al historial delictivo, del cual se espera obtener una mayor disuasión o una mayor contención (inocuización). Conocidas son al respecto las llamadas leyes de "three strikes and you're out" o de "multireincidencia" (MARTINEZ GUERRA, Amparo, Nuevas tendencias político criminales en la función de las Medidas de seguridad. Su repercusión en la legislación española, Madrid: Edit. Dykinson, 2004, pág. 25; SANZ MORAN, Angel, "El tratamiento del delincuente habitual", Política Criminal no 4 (2007), pp. 1-16, http://www.políticacriminal.cl, págs. 4-5). A ello se suma la aplicación de regímenes de cumplimiento de la privación de libertad especial o extraordinario al previsto para la pena normal, en base a la supresión de la aplicación de los institutos que relajan las condiciones aflictivas que son propias de su ejecución. En la actualidad se incorporan mecanismos complementarios de naturaleza similar como la extended sentence o la indeterminate sentence introducidas (Criminal Justice Act de 2003) en el modelo Inglés (del todo asimilables a una medida de seguridad MARTINEZ GUERRA, op. cit., pp. 23 y ss.; ROBLES PLANAS, " $<$ Sexual Predators>, cit. nota $\mathrm{n}^{\circ} 7$, pp. 5 y ss.; Oo. en SANZ MORAN, "El tratamiento", op. cit., p. 6), diversas modalidades de control no privativo de libertad a ser aplicadas en forma posterior o paralela al cumplimiento de la pena (castración química, el control telemático, la imposición de órdenes de permanencia o alejamiento de lugares, actividades o personas y diversas modalidades rígidas de ejecución de libertad vigilada o controlada). 
MALDONADO, Francisco. “¿Se puede justificar la aplicación copulativa de penas y medidas de seguridad? Estado actual de las posiciones doctrinales

que buscan dicho objetivo".

ambas pues con ello no se abordan ni explican las complejidades que propone su interconexión en torno a un mismo y único objetivo.

\subsection{EI dualismo restringido o "flexible". 46}

\subsubsection{Fórmula propuesta.}

Las observaciones expuestas no han decantado en exclusiva en un rechazo a la idea de que el sustento independiente o autónomo de pena y medida permite aceptar un dualismo de ejecución. Un sector de la doctrina ha pretendido hacerse cargo de las interconexiones antes advertidas bajo el entendido de que es posible conservar la propia independencia operativa de ambas herramientas. La idea de base es que éstas han adaptado sus presupuestos estructurales (originales) a partir de los límites y restricciones que supone su consideración dual en un mismo sistema, lo que lleva a contenidos cuya legitimidad no se discute. Cada reacción habría incorporado por ello los efectos de la interacción dualista en sus propios parámetros de legitimación permitiendo hacer pervivir la idea de que son dichos presupuestos autónomos los que justifican una ejecución complementaria en caso que dichos límites concedan espacios de actuación diversos a pena y medida. ${ }^{47}$

A este respecto quisiéramos destacar el planteamiento defendido por Silva Sánchez, en tanto propone una caracterización del dualismo que se hace cargo de buena parte de las observaciones antes formuladas y da un paso más. Comparte en primer lugar el que ha sido la propia evolución histórica de los modelos penales la que permite llegar a aceptar el dualismo como fórmula de reacción penal, en cuanto es claro que han cambiado las condiciones originales que llevaron a objetarlo. ${ }^{48}$ Entiende también que en dicho desarrollo han sido determinantes los acercamientos experimentados entre ambas reacciones, destacando tanto el papel que al respecto cumple la irrupción de la prevención en el ámbito de la pena, como también el hecho de que la medida ha dejado de ser considerada como una especie de terapia neutral, carente de contenido aflictivo o perjudicial para los intereses del individuo que las padece. ${ }^{49}$ Por otro lado, advierte que ambas herramientas cuentan con un sustento de legitimidad que supera la mera aplicación consecuencialista o utilitarista en base a fines sociales, sea que radique en la culpabilidad (respecto a la pena) o en la exigencia de adecuación a una regla de proporcionalidad (aplicable a la medida de

\footnotetext{
${ }^{46}$ Terminología tomada de SANZ MORAN, Las medidas de corrección, cit. nota n ${ }^{\circ}$ 10, p. 45.

${ }^{47}$ En esta dirección destacan las posiciones de SILVA SÁNCHEZ ("La regulación", cit. nota n ${ }^{\circ} 10$, y en "Delincuencia patrimonial leve: una observación del estado de la cuestión", EPC, Vol. XXV (2005), Santiago de Compostela, pp. 333 a 360; También publicado en VV.AA., Dogmática y Criminología. Dos visiones complementarias del fenómeno delictivo. Homenaje a Alfonso Reyes Echandia, Bogotá: Edit. Legis, 2005, pp. 567 y ss.) y SANZ MORAN ("El tratamiento", cit. nota $\mathrm{n}^{\circ} 45 \mathrm{y}$ en: "De nuevo sobre el tratamiento del delincuente habitual peligroso", en VV.AA., Derecho penal y criminología como fundamento de la política criminal: estudios en homenaje al profesor Alfonso Serrano Gómez, Madrid: Edit. Dykinson, 2006, pp. 1085 a 1101), en España.

${ }^{48}$ Entiende que hay un tránsito desde lo utilitario a un modelo compatible con el Estado de Derecho centrado en frenos al mero consecuencialismo, desarrollo que permitiría superar la calificación del modelo resultante como uno que resulta endémicamente aquejado por un estado de crisis. En este sentido también SANZ MORAN, Las medidas de corrección, cit. nota n 10, pp. 84-5.

${ }^{49}$ SILVA SÁNCHEZ, "La regulación”, cit. nota n 10, p. 25.
} 
seguridad), ${ }^{50}$ sosteniendo asimismo las razones por las cuales entiende que ambas son igualmente necesarias y deben por ello conservar su propia individualidad. ${ }^{51}$

Sobre estas bases configura un modelo integrado que se aleja del marco regulatorio estricto de la pena como también de los criterios que orientan a la medida de seguridad. No obstante, no se conforma con la tradicional exigencia que demanda el juicio de proporcionalidad para legitimar la medida de seguridad, en cuanto juicio centrado en un análisis sobre la racionalidad del sacrificio que supone la medida en relación al mal que se pretende evitar, recurriendo en su lugar a contenidos más generales. A este respecto señala:

"habría de tratarse de medidas regidas por un criterio de proporcionalidad que determine -valorativamente- el momento en que el riesgo de reincidencia pasa a ser asumido por el conjunto de la sociedad, como parece razonable que tenga lugar en el marco de un Estado de derecho que disponga una distribución equilibrada de cargas entre individuo y sociedad". 52

Se trata en el fondo de un ejercicio ponderativo que se desenvuelve en un nivel diverso, y que pone de relieve que la decisión sobre la proporcionalidad de la medida de seguridad no se desarrolla sólo en función (y en atención) al peso específico de los intereses particulares en juego.

A partir de este supuesto Silva Sánchez descarta que el modelo pueda llegar a instancias extremas, asumiendo, por ejemplo, que la inocuización constituye una "distribución desequilibrada de cargas en perjuicio del penado", toda vez que las consideraciones que deben brindarse a los derechos fundamentales de la persona exige mantener siempre la posibilidad de "resocialización" (reinserción) a partir de lo cual concluye que la sociedad debe "estar dispuesta necesariamente a soportar un riesgo para la seguridad de la colectividad". 53

Lo dicho deja en claro que este autor sostiene la posibilidad legítima de aplicar medidas de seguridad en forma copulativa y suplementaria a una pena (superando con ello los límites que propone la culpabilidad), cuando menos, en casos de habitualidad asociada a casos de criminalidad grave, sin que dichas reacciones lleguen a sobrepasar los límites que el Estado ha asociado con las esferas de su propio riesgo. ${ }^{54} \mathrm{Si}$ bien considera deseable procurar evitar la duplicidad de reacciones (para lo cual adhiere a la general tendencia a recurrir a fórmulas de vicarialidad) entiende que dicho objetivo solo resulta posible de satisfacer en caso que

\footnotetext{
${ }^{50}$ SILVA SÁNCHEZ, “La regulación”, cit. nota n 10, p. 26.

${ }^{51}$ SILVA SÁNCHEZ, "La regulación”, cit. nota $\mathrm{n}^{\circ}$ 10, pp. 22 y 32; y “¿Medidas de seguridad”, cit. nota ${ }^{\circ}$ 24, p. 889; En el mismo sentido SANZ MORAN, Las medidas de corrección, cit. nota n 10, p. 70 y en "De nuevo sobre el tratamiento", cit. nota ${ }^{\circ} 47$, p.1087.

${ }^{52}$ SILVA SÁNCHEZ, Jesús María, "El retorno a la inocuización. El caso de las reacciones jurídico-penales frente a los delincuentes sexuales violentos", en VV.AA., Homenaje al Dr. Marino Barbero Santos. In Memoriam, Ediciones Universidad Castilla-La Mancha / Cuenca: Ediciones Universidad Salamanca, 2001, p. 709

${ }^{53}$ SILVA SÁNCHEZ, "El retorno", cit. nota n 52, p. 710.

${ }^{54}$ En el mismo sentido SANZ MORAN, Las medidas de corrección, cit. nota ${ }^{\circ} 10$, pp. 84-5, quien lo vincula específicamente a la subsidiariedad y a la proporcionalidad.
} 
MALDONADO, Francisco. “¿Se puede justificar la aplicación copulativa de penas y medidas de seguridad? Estado actual de las posiciones doctrinales

que buscan dicho objetivo".

ambas reacciones presenten grados de coincidencia. En los demás casos -concluye- el exceso que puede presentar la medida de seguridad quedará cubierto y legitimado por sus propias bases de justificación.

\subsubsection{Valoración crítica.}

A nuestro juicio este planteamiento no logra resolver satisfactoriamente algunas de las observaciones antes esbozadas. En primer lugar parece claro que en el funcionamiento de esta dinámica de justificación no resulta posible desligar el marco de garantías que se proponen para caracterizar el uso de la medida de seguridad de algunos de los riesgos tradicionales que plantea la consideración de la peligrosidad, particularmente teniendo en cuenta que el argumento de estricta necesidad y la propia proporcionalidad son, en definitiva, instancias ponderativas permeables a las valoraciones de entidad que puedan proponerse respecto de las necesidades de prevención. Se trata de una estructura plenamente funcional a una mayor ampliación de los contenidos de aflictividad que se pueden llegar a estimar tolerables, lo que la ubica muy lejos de los objetivos limitativos o de control que se esgrimen como argumento basal.

Queda en evidencia en cuanto Silva Sánchez reconoce formalmente la necesidad de considerar elementos de valoración que, a fin de cuentas, llevan a definir lo tolerable a partir de una decisión de evidente carácter político y que, por lo demás, admite llegar a cargar al individuo con parte (y buena parte) de los riesgos que manan de un supuesto que no le resulta atribuible en modo alguno.

Pero más relevante aun parece el que se propone una conceptualización de la proporcionalidad que plantea una razón adicional para apreciar una contradicción directa con la propia culpabilidad y sus límites. No sólo mantiene el problema de que la aceptación de la aplicación de medidas de seguridad adicionales a la pena hace que pierda todo sentido, y con carácter general, la propia regulación de la culpabilidad como límite. Además de ello (y por lo mismo), se atribuye a ambos conceptos una función definitoria idéntica, cual es, determinar la forma como se van a distribuir los costos y cargas sociales que emanan del delito. ${ }^{55}$ Esta coincidencia en el plano de lo material obliga a optar por uno de ellos en casos de contradicción, siendo inevitable concluir que la primacía de cualquiera hará que pierda todo sentido la consideración del otro como instancia delimitativa. En efecto, de aceptarse el límite de la culpabilidad como fórmula que determina cuando es el

\footnotetext{
${ }^{55}$ Se toma como premisa que las relaciones personales en sociedad se definen a partir de la idea de autonomía a consecuencia de las exigencias que impone el principio democrático. Muñoz Conde lo expresa con claridad recordando que dicha noción es mas bien un concepto que se define conforme a los caracteres de cada lugar y momentos histórico (superando con ello cualquier perspectiva ontologicista que, a decir verdad, y mas allá de sus debilidades, poco aporta a su caracterización concreta), estructurándose los espacios de desarrollo autónomo de cada individuo en base a un punto de equilibrio que sitúa el marco (lugar y extensión) de desarrollo de la libertad individual, que se refleja de manera precisa en el concepto de culpabilidad. Dicha noción constituye por ello una válvula que opera a estos efectos como criterio definitorio, que separa los ámbitos de la libertad de los que definen el marco de la responsabilidad (aquello que se nos puede exigir). MUÑOZ CONDE, Derecho Penal, cit. nota n 44, pp. 53,54, 58. En el mismo sentido ROXIN, Claus, "Que queda de la culpabilidad en Derecho penal", Cuadernos de Política criminal $\mathrm{N}^{\circ} 30$ (1986), p. 686.
} 
individuo el que debe soportar los costos del delito y cuales son de carga de la sociedad, debe concluirse necesariamente que la proporcionalidad no puede a la vez cumplir el mismo papel, invirtiéndose la conclusión en caso contrario. ${ }^{56}$

Por ello la única forma de explicar la presencia de dos límites escalonados de aplicación subsidiaria es contar con un parámetro que recurra a una base diversa de legitimación capaz de precisar y justificar cuándo podemos pasar del uno al otro. Esta necesidad parece intuirse en la postura de Silva Sánchez por el hecho de que propone considerar parámetros de valoración de la proporcionalidad que se apartan de la tradicional comparación entre el contenido aflictivo de la medida de seguridad y el riesgo o peligro que se desea evitar. Detrás de ello es claro que no considera que dicha fórmula constituya un ejercicio suficiente para justificar un exceso por sobre la culpabilidad, debiendo para ello ponderarse las definiciones generales que adopta la sociedad sobre sus necesidades de seguridad o protección y el respeto que está dispuesta a conceder a la autonomía del individuo. Es precisamente este último valor el que dicho autor estima sacrificable para hacer que el individuo soporte el riesgo de comisión de un nuevo delito, riesgo que en algunos casos la sociedad consideraría (mas bien decidiría) que no debe soportar.

De esta forma, este ejercicio ponderativo no puede ser entendido como un criterio alternativo que sustituya al anterior, sino que corresponde a un análisis diverso al que propone la idea de proporcionalidad. Se trata de una valoración paralela y complementaria que precisamente coloca a un lado de la balaza a la propia culpabilidad (como referente de la autonomía individual) y al otro lado a las necesidades de prevención y seguridad. ${ }^{57} \mathrm{El}$ único parámetro de control radicaría entonces en que dicho sacrificio pueda ser considerado "razonable". 58

Este análisis empalma con el contenido de lo que se ha dado en llamar principio del interés preponderante y da lugar a una fórmula alternativa que reconoce formalmente la necesidad de recurrir a componentes adicionales a los que proporcionan las lógicas de justificación individuales de la pena y de la medida de seguridad en caso de aplicación copulativa de ambas herramientas, contenidos que por ello se confirmarían como insuficientes a dichos efectos.

\footnotetext{
56 De ahí que el problema que enfrentan estas construcciones sea lograr explicar en qué consiste y qué funciones cumple el límite de la culpabilidad, en cuanto es el propio sistema el que pareciera desacreditar dicha propiedad. Muy gráfico Frisch quien en una muestra de ello destaca (a nivel abstracto) que en los casos en que culpabilidad y prevención especial se muestran muy contrapuestos se debe abandonar la vinculación del modelo a la culpabilidad. FRISCH, "Las medidas de corrección", cit. nota ${ }^{\circ} 13$, p. 20. Conviene recordar al respecto, como hace ZIFFER (Medidas de seguridad, cit. nota $n^{\circ} 15$, p. 39) que: "la función tradicional asignada en derecho penal al principio de culpabilidad es la de contrarrestar los afanes preventivos de la sociedad".

${ }^{57}$ ROXIN, Derecho Penal, cit. nota n ${ }^{\circ} 13$, p. 105.

${ }^{58}$ SILVA SÁNCHEZ, "El retorno a la inocuización”, cit. nota n 52, p. 710.
} 
MALDONADO, Francisco. “¿Se puede justificar la aplicación copulativa de penas y medidas de seguridad? Estado actual de las posiciones doctrinales

que buscan dicho objetivo".

\section{Las fuentes externas de legitimación.}

\subsection{El interés preponderante en la prevención del delito.}

\subsubsection{Fórmula propuesta.}

Las tesis que buscan justificar las medidas de seguridad detrás de la lógica de la ponderación de intereses ( $\mathrm{y}$, más precisamente, en la afirmación de un interés preponderante en la prevención del delito) concitan en la actualidad el mayor campo de adhesiones, constituyendo sin lugar a dudas la doctrina mayoritaria o dominante en esta materia. ${ }^{59}$ La formulación originaria de la tesis se atribuye a Nowakowski ${ }^{61} \mathrm{y}$ data de la década del 50. La idea central consiste en asumir que se puede recurrir a las medidas de seguridad "cuando las necesidades públicas de seguridad frente a la peligrosidad del delincuente pesen más que los derechos individuales de éste". ${ }^{62}$ Se trata de un ejercicio de ponderación de intereses que confronta los derechos del individuo y el interés público de prevenir delitos, como parte de la función -más general- de dar protección y seguridad a la generalidad de la población.

La ventaja de este planteamiento -precisa Nowakowski- es que el criterio propuesto va más allá de la mera exigencia de utilidad social ("beneficio para la comunidad") radicando lo que denomina la "justificación moral" de las medidas de seguridad en el (indubitado) "mayor peso" que debe cobrar el interés público en prevenir futuros delitos, todo ello como resultado de un ejercicio concreto de ponderación. ${ }^{63}$ Se postula por ello que en los demás

\footnotetext{
${ }^{59}$ Dicha calificación se constata por CANO PAÑOS, Miguel Angel, "El marco jurídico y criminológico de la custodia de seguridad en el Derecho penal alemán”, $C P C \mathrm{~N}^{\circ} 91$ (2007), p. 238, DE FIGUEIREDO DIAZ (Direito Penal, cit. nota ${ }^{\circ}$ 39, p. 92), SANZ MORAN ("Sobre la justificación de las Medidas de Corrección y seguridad", en JORGE BARREIRO (edit.): Homenaje al profesor dr. Gonzalo Rodríguez Mourullo, Madrid: Edit. Thomson/Aranzadi, 2005, p. 973), y ZIFFER (Medidas de seguridad, cit. nota ${ }^{\circ}$ 15, p. 78). Entre otros, adhieren a ella ROXIN (Derecho Penal, cit. nota $\mathrm{n}^{\circ} 13$, pp. 43 y 104 y ss.) y JESCHECK/WEIGEND (Tratado de Derecho Penal, cit. nota ${ }^{\circ} 13$, pp. 865, 866 y 877) este último en base a un contenido incorporado sólo en la $5^{\text {a }}$ edición, manteniéndose Jescheck, en las ediciones anteriores, estrictamente apegado a una tesis centrada en la constatación de un abuso de la libertad.

${ }^{60}$ En términos estrictos debemos reconocer que la mayoría sostiene un fundamento diversificado, recurriendo a contenidos diversos para legitimar las medidas alternativas o sustitutivas de pena y las que se imponen en forma complementaria a la misma. Es en este último plano donde el interés preponderante es acogido en forma predominante por la doctrina, recibiendo escasa aplicación en los demás casos. De ahí que proponga una especial caracterización para el exceso por sobre la medida de la culpabilidad. Así se aprecia, por ejemplo, en CEREZO MIR (en Curso, cit. nota ${ }^{\circ} 13$, pp. 36 y 37), GRACIA MARTIN, Luis "Sobre la legitimidad de medidas de seguridad contra delincuentes imputables peligrosos en el Estado de Derecho" en: VV.AA. Estudios penales en Homenaje a Enrique Gimbernat, Tomo I, Madrid: Ed. Edisofer, 2008, pp. 988-9 y 997; y en STRATENWERTH (Derecho Penal, cit. nota ${ }^{\circ} 24$, pp. 41 y ss.), uno de los principales defensores de esta tesis. En un sentido similar en Chile GUZMAN DALBORA, La pena y la extinción, cit. nota ${ }^{\circ} 4$, p. 87.

${ }^{61}$ DE FIGUEIREDO DIAS, Direito Penal, cit. nota ${ }^{\circ} 39$, p. 92

${ }^{62}$ SANZ MORAN, "Sobre la justificación”, cit. nota n 59, p. 973.

${ }^{63}$ La mayor "ventaja" que presenta a estos efectos es que, en general, dicho interés global siempre puede llegar a ser considerado de mayor valor que el contenido concreto que se estima sacrificable. Como indica GUZMAN DALBORA (La pena y la extinción, cit. nota $\mathrm{n}^{\circ} 4$, p. 90) el "voraz apetito de la defensa social (...) tiene una "magnitud (...) inconmensurable".
} 
casos "la sociedad tiene que asumir el riesgo de ulteriores delitos", lo que en concreto significa que una baja peligrosidad o una baja gravedad del delito constituyeran bases insuficientes de justificación, configurando a las medidas de seguridad como una herramienta de excepción. Esta es la única diferencia que plantea el ejercicio de ponderación con la sola referencia a la utilidad social.

Como podrá apreciarse Nowakowski no alcanza a desarrollar en su planteamiento referencias concretas a algún criterio u orientación que nos permita determinar (o siquiera intuir) en términos más precisos, o de forma más objetiva, cuándo nos encontraremos frente este "mayor peso" del interés público de prevención, en algo que vaya más allá de una genérica valoración de la peligrosidad y de la gravedad del delito. De hecho y, en cierta medida reconociendo que se concibe dicha decisión como una cuestión político criminal radicada en los ámbitos decisorios del legislador, especifica que se trata de una contraposición del interés social comprometido con el valor y la dignidad del hombre, asumiendo que "cuando más alto precio reciban (estos últimos) por parte del ordenamiento jurídico, más se estrechará el círculo de peligros frente a los que vienen en consideración las medidas". 64

En la actualidad se atribuye a Stratenwerth el haber desarrollado una estructura que permite darle una mayor concreción a la formulación original. Dicho autor también parte de la base de que la peligrosidad del individuo (como presupuesto) y la idoneidad de la medida (como cualidad) no bastan para justificar injerencias en los derechos y libertades, especificando que la insuficiencia de dichos parámetros radica en que solo aportan un contenido parcial en la definición de cada uno de los elementos que debe ser ponderado para arribar a un fundamento. "Lo decisivo (es) determinar si el peligro que emana del autor para intereses jurídicamente protegidos tiene tanto peso como para que aparezca razonable la injerencia en sus derechos personales, necesaria para replicar ese peligro", ${ }^{65}$ elevándose aquél como un “interés público preponderante.". ${ }^{6}$

La mayor concreción que se atribuye a la aportación de Stratenwerth consiste básicamente en que se ocupa de precisar criterios que permiten desarrollar dicho ejercicio agregando a los ya mencionados (la entidad del interés público en evitar los potenciales delitos configurada en atención a su gravedad y a la probabilidad de su comisión) el que debe considerarse en particular contenido de gravedad de la medida de seguridad, incluyendo en ello su aflictividad concreta (no sólo su duración) y su naturaleza. Agrega el deber de verificar si además de servir una finalidad general su ejecución mira también en beneficio del mismo sujeto. ${ }^{67}$ Destaca asimismo que la ponderación debe realizarse conforme a los caracteres de caso a caso en concreto, sin que sea posible aventurar o anticipar conclusiones o valoraciones en base a supuestos abstractos de nivel general. ${ }^{68}$

\footnotetext{
${ }^{64}$ SANZ MORAN, "Sobre la justificación”, cit. nota ${ }^{\circ}$ 59, p. 973.

${ }^{65}$ STRATENWERTH, Derecho Penal, cit. nota ${ }^{\circ} 24$, p. 44.

${ }^{66}$ STRATENWERTH, Derecho Penal, cit. nota ${ }^{\circ} 24$, p. 43.

${ }^{67}$ STRATENWERTH, Derecho Penal, cit. nota n 24, p. 44. En el mismo sentido SANZ MORAN, "Sobre la justificación", cit. nota ${ }^{\circ}$ 59, p. 973.

${ }^{68}$ STRATENWERTH, Derecho Penal, cit. nota ${ }^{\circ} 24$, p. 44.
} 
MALDONADO, Francisco. “¿Se puede justificar la aplicación copulativa de penas y medidas de seguridad? Estado actual de las posiciones doctrinales

que buscan dicho objetivo".

\subsubsection{Valoración crítica.}

A simple vista parece relativamente evidente que el desarrollo expuesto no proporciona elementos de juicio que permitan avanzar en forma decisiva en una línea de justificación. Y no se trata sólo de una cuestión que afecta a la insuficiencia de los contenidos propuestos para el desarrollo de la ponderación, ${ }^{69}$ sino de una de carácter estructural. ${ }^{70}$

Hay que tener en cuenta que la tesis del interés preponderante constituye en el fondo una reformulación de la perspectiva utilitaria, de la cual solo se distingue por el hecho que plantea una relación concreta de justificación que debe ser sometida a análisis en lugar de presumirla en base la sola afirmación de razones de mera utilidad o necesidad social. El aporte que de ello se extrae es el reconocimiento que supone de que el interés social que sea sustentado debe ser incorporado dentro de uno de los platos de la balanza. Por sobre ello las diferencias son claramente difíciles de apreciar pues, en términos materiales, se propone una base de sustento a partir de la afirmación de que la medida de seguridad es "útil" (idónea y requerida o necesaria) para la "defensa de la sociedad".

Se trata de una cuestión de matices que vale la pena precisar. Para el positivismo y la defensa social es la eficacia lo que opera como criterio determinante (en cuanto más efectiva sea la intervención mas razonable es su uso) ${ }^{71}$ mientras que en este caso pareciera que dicha valoración es considerada insuficiente. Se debe demostrar además que dicha herramienta (útil, por cierto) es necesaria, es decir, que cumple un objetivo requerido que no se puede alcanzar de otra forma, valoración que es adoptada a partir de una definición normativa centrada en el interés general de protección de la sociedad.

Esta constatación permite claramente diferenciar este análisis del que propone el principio de proporcionalidad (como ya se sostiene en la postura de Silva Sánchez). En ambos casos se desarrolla una misma mecánica de aproximación que por lo demás también se orienta al objetivo de determinar el marco de lo tolerable. Sin embargo es en el ámbito de los contenidos sujetos a la ponderación donde se pueden apreciar diferencias sustanciales entre ambos conceptos, concentrándose la tesis del interés preponderante en las dimensiones sociales que caracterizan a la ejecución de un ilícito penal. ${ }^{12}$ Como anticipamos no se trata

\footnotetext{
${ }^{69}$ FRISCH ("Las medidas de corrección", cit. nota ${ }^{\circ} 13, \mathrm{p} .23$ ) pone de relieve que a la hora de emprender la tarea de proponer una mayor concreción el grueso de las opiniones recurre básicamente a los mismos criterios elaborados por Exner en 1914 en base a una perspectiva netamente utilitarista, siendo fácil por ello prever que no se arribará a conclusiones aceptables.

${ }^{70}$ Por todos, SCHÜNEMANN, Bernd, "La función del principio de culpabilidad en el derecho penal preventivo", en DEL MISMO, (Coord.): El sistema moderno del Derecho Penal: Cuestiones fundamentales. Estudios en honor de Claus Roxin en su 50 aniversario (Introducción, traducción y notas de Silva Sánchez), Madrid: edit. Tecnos, 1991, p. 163 Nota 39, quien considera que un ejercicio como el propuesto es no solo insuficiente sino además incorrecto.

${ }^{71}$ Por todos, CASABÓ RUIZ, José Ramón, "El fundamento de las medidas de seguridad", en VV.AA., Peligrosidad social y medidas de seguridad. La ley de peligrosidad y rehabilitación social de 4 de Agosto de 1970, Colección de Estudios, Universidad de Valencia, 1974, pp. 48-9.

${ }^{72}$ En Roxin se aprecian claramente las diferencias conceptuales (Derecho Penal, cit. nota $\mathrm{n}^{\circ} 13$, pp. 103 a 106). No obstante ello el planteamiento no aparece directamente disociado del criterio de proporcionalidad entendiendo este autor que es este principio el que cumple y satisface la tarea de concretar la ponderación de
} 


\section{Polit. crim. Vol. 6, No 12 (Diciembre 2011), Art. 5, pp. 387 - 447. [http://www.politicacriminal.cl/Vol_06/n_12/Vol6N12A5.pdf]}

en este caso de sopesar el valor del bien que se sacrifica con el que se pretende precaver, representado este último en el bien jurídico concreto cuya afectación más que probable se pronostica a partir del juicio de peligrosidad, sino del interés social que concurre en su protección, referente diverso y de evidente contenido general. ${ }^{73}$

Lo más relevante sin embargo es que la formulación deja en claro que la afirmación acerca de que concurre un interés preponderante se realiza respecto al papel y significado que cumple la culpabilidad, constituyendo éste y no el contenido restrictivo de la medida de seguridad el referente que se pretende anular a partir del mayor valor de los intereses generales. ${ }^{74}$ Así se ratifica expresamente por algunos de los partidarios de esta tesis ${ }^{75}$ y se confirma si recordamos que el objetivo perseguido a través de su formulación es precisamente llegar a justificar la aplicación de una medida de seguridad por sobre el límite de la culpabilidad.

Este carácter o función -que ya advertimos- ratifica una vocación netamente utilitarista o, si se prefiere, el que a nivel material cumple un papel plenamente funcional a una perspectiva que da crédito a razones de mera utilidad social por sobre el contenido de las garantías individuales. ${ }^{76}$ Constituye por ello una fórmula que sólo en el nivel formal plantea una base de justificación, pero que a fin de cuentas carece de contenido material realmente

bienes comprometida, planteando con ello un grado de concreción mayor. Entendido de esta forma, la proporcionalidad cumple una triple perspectiva: sustituye a la culpabilidad en cuanto fundamento personal (merecimiento) y en cuanto medida límite de la intervención (prohibición de exceso), pero además pasa a constituir la base de justificación de las MSC, al concretar o servir de puente a la resolución de la colisión implícita en la "ponderación de intereses".

${ }^{73}$ FRISCH, "Las medidas de corrección", cit. nota $\mathrm{n}^{\circ} 13$, p. 33. Hay que tener en cuenta que la idea de proporcionalidad adquiere un mayor desarrollo en el ámbito del derecho público a partir de la postguerra, particularmente en torno a la necesidad de establecer parámetros fijos capaces de legitimar la imposición de medidas coactivas regidas por objetivos relativos a la prevención de daños. Pero se trata de un desarrollo que preferentemente tiene lugar en torno a intervenciones que son propias del derecho administrativo, cobrando también sentido para legitimar intervenciones coactivas en casos extremos donde la inminencia del daño juega un papel fundamental, cumpliendo en general el papel de ratificar o condenar una actuación pública ya realizada. Sólo a partir del desarrollo de la tesis que ahora comentamos, unido al asentamiento de la orientación preventiva del derecho penal y probablemente teniendo en cuenta que el origen de las medidas de seguridad precisamente radica en el derecho administrativo de policía, es que esta orientación propia de la proporcionalidad (centrada en la ponderación de los intereses particulares comprometidos) pasa a cobrar sentido para la legitimidad de las medidas de seguridad. Inicialmente ello tiene lugar en base a paralelos concretos con institutos como la legítima defensa o el estado de necesidad, siendo la distancia que separa en estos casos a la propia intervención a través de una medida de seguridad del daño que se pretende precaver, la que lleva a potenciar el uso de una perspectiva más general. De esta forma es indiscutible que se trata de un principio que algo tiene que decir en este ámbito, pero que tiene un contenido, objetivos y, consecuentemente, cumple una función distinta.

${ }^{74}$ En este sentido, concretamente, SÁNCHEZ LAZARO (“Un problema de peligrosidad", cit. nota n 11 , pp. 150-1.) quien pone de relieve que el uso de este criterio lleva a obviar por completo el significado de la dignidad humana, representado precisamente en la culpabilidad.

${ }^{75}$ Por todos, ROXIN (Derecho Penal, cit. nota $\mathrm{n}^{\circ} 13, \mathrm{p} .106$ ) quien expresa que la dinámica de "ponderación de intereses" se desarrolla entre las necesidades de protección social y el valor y la dignidad del individuo.

${ }^{76}$ En este sentido Schünemann destaca que dicho criterio "no aporta nada a la prevalencia del interés estatal de aseguramiento realizado con las medidas a costa del interés individual", pues al encontrarse referido dicho principio en exclusiva a las "necesidades de aseguramiento" se configura un argumento que equivale a la mera utilidad funcional (prevención). Vid. SCHÜNEMANN, "La función del principio", cit. nota $n^{\circ} 70, \mathrm{p}$. 163 , nota 39 . 
MALDONADO, Francisco. “¿Se puede justificar la aplicación copulativa de penas y medidas de seguridad? Estado actual de las posiciones doctrinales

que buscan dicho objetivo".

contrastable, lo que se refleja en un nulo rendimiento a efectos limitativos. ${ }^{77}$ En los hechos la tesis se limita a proporcionar una especie de motivo, una razón cargada de elementos retóricos o argumentativos, que no parecen ir más allá del objetivo de dotar a estos casos de una apariencia de legitimidad. ${ }^{78}$

De ahí que el sólo hecho de recurrir a "la protección de la libertad y seguridad de todos, es decir, de la prevención del delito.", ${ }^{79}$ como interés que en concreto que contrapone (y debe contraponerse) a la idea de culpabilidad, traiga a colación nuevamente la idea de que estamos frente a un fraude, pues parece claro que carece de todo sentido sustentar un límite (la culpabilidad) donde la orientación restringida (la prevención) cuenta con plena virtualidad para llegar a superarlo. ${ }^{80}$

A partir de esta contundente objeción se desarrollan reacciones diversas. Se opta en algunos casos por agregar elementos de legitimación adicionales; otros buscan más bien profundizar en la precisión de los criterios, elementos e incluso del ámbito de incidencia de la ponderación; Un tercer grupo pretende sustituir el referente colectivo (el interés "público" preponderante) por la lógica de la colisión de derechos; y, finalmente, un cuarto grupo se inclina por renunciar a la búsqueda de referentes externos fijando nuevamente la atención en razones vinculadas al merecimiento personal.

\subsection{Complementos: el límite de la dignidad humana.}

Algunos autores han asumido que las objeciones planteadas y, particularmente la recién expuesta, no deben llevar a un rechazo del criterio, siendo suficiente con la consideración de límites adicionales y externos. Así por ejemplo De Figueiredo Días ${ }^{81}$ postula que el principio de ponderación de bienes en conflicto es una base necesaria pero no suficiente para legitimar la imposición de medidas de seguridad entendiendo que debe también acreditarse la satisfacción de un conjunto de requisitos "jurídico constitucionales" referidos a la exigencia de intervención judicial previa (garantía de jurisdiccionalidad o legitimación

\footnotetext{
${ }^{77}$ En este sentido, concretamente, JAKOBS, Günther, Derecho Penal. Parte General. Fundamentos y Teoría de la Imputación., $2^{\circ}$ Edición corregida, (traducción de Cuello Contreras, J. y Serrano González, J.L.), Madrid: Edit. Marcial Pons, 1997, p. 39; FRISCH ("Las medidas de corrección”, cit. nota n 13, pág. 32) destaca que la concreción de la tesis del interés preponderante deja aun más que desear que el propio argumento de necesidad. El riesgo de formalismo ya lo constata ZIFFER (Medidas de seguridad, cit. nota $\mathrm{n}^{\circ}$ 15 , p. 81) a pesar de mostrarse cercana a la tesis de fondo, haciendo depender su utilidad del nivel de concreción de sus contenidos de base.

${ }^{78}$ Como indica NAUCKE, Wolfgang, Derecho Penal. Una introducción. Traducción de la $10^{\circ}$ edic. alemana por Leonardo Brond. Buenos Aires: Edit. Astrea, 2006, p. 36: "la referencia a la protección de muchos miembros de la sociedad como fin de las medidas es una explicación de causas, pero ninguna legitimación".

${ }^{79}$ GRACIA MARTIN, Luis, Fundamentos de dogmática penal. Una introducción a la concepción finalista de la responsabilidad penal, Barcelona: Edit. Atelier, 2006, p. 202, GRACIA MARTIN, Et. Al., Tratado de las consecuencias, cit. nota $\mathrm{n}^{\circ} 11$, p. 364.

${ }^{80}$ En cierta medida lo reconoce Roxin (si bien no en términos explícitos) en cuanto de su postura se extrae de forma evidente el que este criterio permite evaluar cuan en serio nos tomamos el respeto a los derechos fundamentales (Derecho Penal, cit. nota ${ }^{\circ}$ 13, p. 105).

${ }^{81}$ DE FIGUEIREDO DIAS, Direito Penal, cit. nota n 39 , pp. 92 y ss.
} 


\section{Polit. crim. Vol. 6, № 12 (Diciembre 2011), Art. 5, pp. 387 - 447. [http://www.politicacriminal.cl/Vol_06/n_12/Vol6N12A5.pdf]}

por el procedimiento) ${ }^{82}$ y a la "máxima absoluta de preservación de la dignidad de la persona", exigencia que integra en el propio juicio de proporcionalidad. ${ }^{83}$ En concreto, postula que la finalidad de defensa social (prevención de delitos futuros), ${ }^{84}$ directamente vinculada a dicho principio, requiere como complemento el límite que plantea el respeto a la dignidad humana en términos que permiten "rechazar todas aquellas intervenciones preventivas que atenten contra la personalidad moral del individuo". ${ }^{85}$

Estos contenidos limitativos (que configuran una especie de garantía politica) ${ }^{86}$ no son diversos a la exigencia de que la intervención penal deba evitar llegar a afectar la dignidad humana, ${ }^{87}$ la individualidad del sujeto, su autonomía, personalidad moral, ${ }^{88}$ sus derechos esenciales $^{89}$ o que en definitiva no deba materializar un trato inhumano o degradante, conceptos que preferentemente se orientan -en estos casos- a proscribir el uso de intervenciones dirigidas a la mera inocuización. ${ }^{90}$ La idea de base es que a cada individuo le asiste un derecho a conservar las opciones de reinserción en condiciones de normalidad

${ }^{82}$ En un sentido similar respecto de las medidas de seguridad dirigidas a imputables SANCHEZ LAZARO, cit. nota ${ }^{\circ} 11$, p. $154-5$ y $163-4$.

${ }^{83}$ DE FIGUEIREDO DIAS, Direito Penal, cit. nota n 39, p. 94.

${ }^{84}$ Vid. al respecto JORGE BARREIRO, "Reflexiones sobre la compatibilidad", cit. nota $\mathrm{n}^{\circ} 13$, p. 567. Postula que a fin de superar el mero utilitarismo debe inicialmente "conjugarse" dicha finalidad con un ejercicio de ponderación de intereses, identificando a la prevención del delito como un interés preponderante. Ello implica que puede privarse de libertad "cuando su disfrute conduzca con una alta probabilidad a ocasionar perjuicios ajenos (que no precisa, pero de evidente naturaleza social) que pesen más que las restricciones que el causante del peligro deba soportar por la medida de seguridad".

${ }^{85}$ Se trata en el fondo de una extensión de parte de los planteamientos que en su tiempo expuso Welzel para arribar a una justificación ético-social de las medidas de seguridad, constituyendo un reflejo de la adhesión inicial que manifestaba Jorge Barreiro a la tesis que planteaba dicho autor (JORGE BARREIRO, Agustín, Las medidas de seguridad en el derecho español, Madrid: Edit. Civitas S.A., 197, p. 82 y ss.). En Welzel dicho contenido se encontraba asociado a la identificación de un deber del Estado de contribuir a la recuperación de la "plena dignidad" del individuo, en referencia a las condiciones que le permiten desempeñarse en libertad (en términos de Welzel, gozar de "libertad exterior"), argumento que servía de base a dicho autor para legitimar las medidas de seguridad bajo la idea del tratamiento, colocando el centro en la propia dignidad humana. ROCA AGAPITO, Luis, El sistema de sanciones en el Derecho Penal español, Barcelona: Edit. Bosch, 2007, pp. 381 y 383 toma este mismo concepto a objeto de aplicarlo como límite a la doctrina del interés preponderante que parece servirle como base de justificación. Por ello asume que "jamás podrá estar justificada una intervención tal, que comporte un deterioro de componentes esenciales de la personalidad, como sucede, por ejemplo, con la castración o la lobotomía". En el mismo sentido JORGE BARREIRO, Agustín, "Crisis actual del dualismo en el estado social y democrático de derecho", en: Modernas tendencias en la ciencia del derecho penal y en la criminología, Madrid: UNED (actas y congresos), 2001, p. 153.

${ }^{86}$ Terminología tomada a partir de Welzel (WELZEL, Hans, Derecho Penal Alemán. Parte General, $11^{\circ}$ Ed., Trad. Bustos/Yañez, Santiago: edit. Jurídica de Chile, pp. 334-5) por RODRÍGUEZ MOURULLO, Gonzalo, "Significado político y fundamento ético de la pena y la medida de seguridad", Revista General de Legislación y Jurisprudencia, 1965, p. 784.

${ }^{87}$ Idem.

${ }^{88}$ CASABÓ RUIZ, "El fundamento", cit. nota n 71, p. 56; ROCA AGAPITO, El sistema de sanciones, cit. nota ${ }^{\circ} 85$, p. 383.

${ }^{89}$ SILVA SÁNCHEZ, "El retorno", cit. nota n 52, p. 710.

${ }^{90}$ Las referencias expresas de Welzel a este respecto se dirigen a la medida de castración o esterilización prevista en la regulación alemana de 1933 (WELZEL, Derecho Penal Alemán, cit. nota n 86, pp. 334-6); En el mismo sentido RODRÍGUEZ MOURULLO, "Significado político", cit. nota $n^{\circ} 86$, p. 784; JORGE BARREIRO, "Crisis actual", cit. nota $\mathrm{n}^{\circ}$ 85, p. 153; ROCA AGAPITO, El sistema de sanciones, cit. nota ${ }^{\circ}$ 85, pp. 381 y 383; CASABÓ RUIZ, "El fundamento", cit. nota n 71, p. 56. 
MALDONADO, Francisco. “¿Se puede justificar la aplicación copulativa de penas y medidas de seguridad? Estado actual de las posiciones doctrinales

que buscan dicho objetivo".

como una posibilidad real, alternativa que quedaría vedada o que reduce sus posibilidades si la intervención se dirige a su propia anulación, postulado que a estas alturas se presenta y concibe como finalidad o limite autónomo del sistema.

Ahora bien este abanico de conceptos y opciones de sustento de esta exigencia efectivamente avala el consenso existente a este respecto, pero a la vez da cuenta de la falta de claridad que lo rodea, evidenciando escazas certezas en sus contenidos y, con ello, bajas potencialidades limitativas concretas. Basta ver como parece posible afirmar sin mayores dificultades la vulneración de todas y cada una de las nociones comentadas en la ejecución de cualquier sanción penal. ${ }^{91}$ Con ello se demuestra que se trata de una cuestión de grados y que padece de serias dificultades a la hora de pretender alcanzar niveles de concreción reales, mostrándose con claridad solo en torno a casos extremos (V. gr. condena perpetua). ${ }^{92}$

Con ello no solo queda en claro que su papel como límite externo es bastante reducido, sino también el que se trata de una dinámica que, en caso alguno, puede ser considerada como ajena a las perspectivas de la ponderación. En concreto, el mayor problema que deben enfrentar dichas pretensiones limitativas es que su sustento (aun y cuando se plantee que constituye un contenido externo de legitimación) también entra en consideración en el juicio de ponderación, con lo cual, se minimiza bastante la posibilidad de reconocerle un contenido limitativo real. En síntesis la presencia de un interés social de mayor entidad (o de una mas elevada consideración) también podrá reclamar virtualidad, bajo la óptica del interés preponderante, para ir más allá del límite que se propone considerar, sin que con ello se anule su aporte legitimante. ${ }^{93}$

Lo esencial de dicha dinámica de ponderación es que precisamente permite llegar a habilitar cualquier cosa en cuanto parezca necesaria para dar satisfacción a un interés diverso (en este caso de protección social) cuya obtención se muestra o define como preponderante. Sobre esa base no parece haber inconveniente alguno, si se cuenta con un argumento de entidad suficiente (donde pasaría a radica el debate), para reclamar una mayor profundización de la estructura normal, a la cual quedarían relegados los efectos de la culpabilidad y del límite que se plantea respecto de la dignidad humana. ${ }^{94}$

\footnotetext{
91 Al respecto LOPEZ PEREGRIN, Carmen, “¿Lucha contra la criminalidad mediante el cumplimiento íntegro y efectivo de las penas?”, Revista Española de Investigación Criminológica, REIC AC-02-03, en www.criminologia.net, p.17.

${ }^{92}$ Se trata de un problema que es relativamente connatural a todos los casos en que se recurre directamente a argumentos de contenido difuso como la dignidad, personalidad o humanidad del individuo. Sobre ello Vid. HASSEMER, W., "Argomentzione con concetti fondamentalli. L'esempio della dignitá umana", Ars Interpretandi, Annuario di ermeneutica giuridica, $\mathrm{n}^{\circ} 10$ (Valore, Principi e Regole) (2005), Milán, pp. 133-8.

${ }^{93}$ De ahí que autores como Muñoz Conde se inclinen por vincular dichas exigencias directamente a razones de mínima intervención. MUÑOZ CONDE/GARCÍA ARAN, Derecho Penal, cit. nota $n^{\circ} 36$, p. 82. Oo. en GUZMAN DALBORA, La pena y la extinción, cit. nota $\mathrm{n}^{\circ}$ 4, p.86.

${ }^{94}$ Se constata en la propuesta de SILVA SÁNCHEZ quien plantea recurrir al mismo argumento como criterio para la ponderación, postulando con ello su eficacia limitativa desde dentro.
} 


\section{Polit. crim. Vol. 6, No 12 (Diciembre 2011), Art. 5, pp. 387 - 447. \\ [http://www.politicacriminal.cl/Vol_06/n_12/Vol6N12A5.pdf]}

\subsection{Mayor concreción del interés colectivo (Frisch).}

\subsubsection{Fórmula propuesta.}

Desde una perspectiva diversa otros autores han digerido las críticas a la tesis del interés preponderante como desafíos que demandan una nueva mirada sobre sus conceptos esenciales, con miras al perfeccionamiento del criterio. Frisch por ejemplo sostiene que la tesis de la ponderación de intereses plantea un problema cuando el análisis se concentra exclusivamente en la relación entre el interés representado por la libertad o seguridad del destinatario de la medida y el referido a la seguridad general, entendiendo que dichos conceptos solo proporcionan una base inicial a la justificación. Sostiene por ello que se trata de una referencia genérica que por sí sola resulta insuficiente como argumento de legitimación. ${ }^{95}$

Con miras a avanzar desarrolla una primera premisa fundamental referida a constatar que tras dicha antinomia concurren dos deberes de protección estatales y no dos principios de la actuación de particulares, destacando que la defensa de la prevención constituye un deber del Estado tan relevante como el que le asiste en orden a respetar los derechos del individuo. ${ }^{96}$ No se trata por ello solo de la defensa de intereses que son percibidos como valiosos sino que está en juego el ejercicio de funciones que son propias de la actuación de los poderes públicos (protección de derechos y protección de daños), ${ }^{97}$ y que, en cuanto tales, presentan similar entidad. De esta forma con lo que la insatisfacción de cualquiera de ellos constituiría un incumplimiento de parte del Estado. ${ }^{98}$ No obstante asume que la presencia del conflicto entre ambos deberes es una condición inevitable, concluyendo por ello que el sacrificio que ello supone es un supuesto básico de la actuación penal.

La tarea no consiste entonces en el análisis de la legitimidad de las alternativas de sacrificio, sino en precisar la forma en que debe resolverse la procedencia de uno u otro. Asume la tarea de profundizar los contenidos de la ponderación advirtiendo que no se ocupa de ello de manera completa. ${ }^{99}$ En su perspectiva personal deben separarse las condiciones que llevan a hacer primar el deber de protección a través de exigencias que recaen en el hecho, en la valoración de necesidad, en el juicio de proporcionalidad y en el sujeto. En cuanto al hecho, destaca su función material, a la que ya nos hemos referido, extrayendo de ella exigencias de gravedad y naturaleza para la medida de seguridad. ${ }^{100}$ En cuanto a la necesidad, poco agrega a las exigencias de idoneidad y subsidiariedad de la

\footnotetext{
${ }^{95}$ Califica este estadio como el principio de la solución objetando a quienes sostienen la tesis del interés preponderante por entender que solo llegan al nivel de un "preámbulo cuyos lineamientos terminan de repente" (FRISCH, "Las medidas de corrección", cit. nota $n^{\circ} 13$, p. 23). Asume para ello que los intentos de concreción no han logrado superar los referentes clásicos del utilitarismo preventivo destacando que mientras no se arribe a puntos de claridad a este respecto no será posible solucionar de manera adecuada los problemas que se proponen (idem. p. 33). En el mismo sentido ZIFFER, Medidas de seguridad, cit. nota n ${ }^{\circ} 15$, p. 82 .

${ }^{96}$ FRISCH, "Las medidas de corrección", cit. nota ${ }^{\circ} 13$, p. 22

${ }^{97}$ FRISCH, "Las medidas de corrección", cit. nota ${ }^{\circ} 13$, p. 21

${ }^{98}$ Sobre las implicancias de este concepto y su utilización concreta Vid. ZIFFER, Medidas de seguridad, cit. nota $\mathrm{n}^{\circ} 15$, pp. 85 y ss.

${ }^{99}$ FRISCH, "Las medidas de corrección", cit. nota ${ }^{\circ} 13$, p. 30.

${ }^{100}$ FRISCH, "Las medidas de corrección”, cit. nota ${ }^{\circ} 13$, p. 29
} 
MALDONADO, Francisco. “¿Se puede justificar la aplicación copulativa de penas y medidas de seguridad? Estado actual de las posiciones doctrinales

que buscan dicho objetivo".

medida; y en cuanto a la proporcionalidad propone un análisis concreto e independiente de gravedad de los intereses particulares comprometidos. Lo más llamativo, sin embargo, se plantea en torno a la caracterización del infractor, donde se concentra en detallar una serie de presupuestos que permitan afirmar una actitud, decisión o dificultad manifiesta y creciente para desarrollar una conducta conforme a la norma, aun y cuando ella obedezca a situaciones determinadas y coyunturales. ${ }^{101}$ Aclara que dicha disposición no se extrae necesariamente de una multiplicidad de hechos (pero reconoce que se trata de una condición evidente) y que dicho dato debe además apoyarse en una valoración de perspectivas de futuro (por ejemplo a ser compensado con una pérdida de capacidad para la actividad delictiva futura).

\subsubsection{Valoración y crítica.}

Lo primero a destacar es que Frisch se ocupa de relevar el carácter público de los intereses en juego sin extraer de ello directamente criterios o contenidos que le ayuden a resolver el ejercicio ponderativo y, con ello, a determinar una regla en este nivel. En primer lugar en cuanto el equilibrio natural de dichos intereses le llevan a evitar todo tipo de valoraciones centradas en su peso o apreciación general, obligando a un ejercicio ponderativo de carácter concreto, centrado en contenidos diversos. Con ello no logra superar el problema de la legitimación de base (como pretende) pues éste en definitiva queda igualmente reservado para la determinación de los casos en que el mecanismo habilita a una intervención por sobre la culpabilidad. Pero además pareciera a corto andar olvidarse de dicho contenido de igualdad toda vez que asume que por definición es preferible una opción menos invasiva para los intereses individuales, a partir de lo cual reserva la medida para casos de aplicación subsidiaria y excepcional.

Por otro lado a la hora de avanzar en la concretización del ejercicio no logra apartarse de los criterios y contenidos tradicionales que ayudan a resolver la ponderación, salvo en cuanto incorpora exigencias concretas de valoración personal que no son diversas al desarrollo de un pronóstico de peligrosidad. Con ello -que constituye una novedad en este contexto- propone un ejercicio que, en definitiva, concentra los resultados en la apreciación de dichos contenidos personales, acercándose peligrosamente a una fuente material propia de la tradicional noción de culpabilidad por el carácter. De esta forma su planteamiento pareciera proponer un esquema donde son dichas condiciones las que soportan el peso moral o ético de la justificación, renunciando en los hechos a radicar el fundamento en una perspectiva externa como la que propone la ponderación de intereses. Se trata por lo demás de una cuestión plenamente intencional en la perspectiva de Frisch quien destaca las ventajas que ello presenta para explicarle al infractor de mejor forma por qué su caso es diverso al de todos aquellos que gozan de la garantía de la culpabilidad. ${ }^{102}$

\footnotetext{
${ }^{101}$ FRISCH, "Las medidas de corrección", cit. nota $n^{\circ} 13$, pp. 26-7

${ }^{102}$ FRISCH, "Las medidas de corrección", cit. nota $n^{\circ} 13$, p. 26
} 


\section{Polit. crim. Vol. 6, № 12 (Diciembre 2011), Art. 5, pp. 387 - 447. [http://www.politicacriminal.cl/Vol_06/n_12/Vol6N12A5.pdf]}

\subsection{La búsqueda de un equivalente en la colisión de derechos: la analogía con la legítima defensa y con el estado de necesidad.}

\subsubsection{Fórmula propuesta.}

También se ha procurado corregir los defectos de la tradicional perspectiva de la ponderación de intereses modificando la forma o dinámica que debe regir el proceso de valoración. Para ello algunos autores retoman los contenidos originales que caracterizaron a los institutos asegurativos (como la medida de seguridad) configurándolos como una colisión de derechos individuales que se resuelve en base a criterios externos que permiten configurar una situación de necesidad. Se renuncia en ello a los contenidos de valor de cada interés, distanciándose de la proporcionalidad, centrando el argumento (y con ello el fundamento) en el hecho de que la peligrosidad constituye una forma de agresión, hecho que por sí solo amerita una reacción defensiva (legítima). ${ }^{103}$ En esta dirección se orientaron autores como Sax o Hanack, ${ }^{104}$ quienes plantearon la necesidad de configurar el fundamento bajo las perspectivas que propone la legítima defensa. ${ }^{105}$ Otros como Schunemann adoptan perspectivas similares en torno a la caracterización del estado de necesidad. ${ }^{106}$

\footnotetext{
${ }^{103}$ Se trata de un desarrollo que no llega a imponerse pero que hoy en día recobra plena actualidad en torno a las necesidades de defensa de la sociedad respecto de nuevos y grandes riesgos que amenazan con destruirla, cuyas dimensiones y efectos incalculables hacen posible actuar de manera preventiva frente a ellas. Se configura sobre esa base lo que se ha dado en llamar estado de necesidad preventivo, donde la inminencia del daño es siempre actual. Por esta vía se trata de justificar un permanente estado de necesidad (emergencia) que habilita a intervenir en forma preventiva, materialmente efectiva, proactiva o de actuación ex - ante, a ser ejercida sobre los supuestos que constituyan muestras de peligro de producción de daños o condiciones que conlleven riesgo de producirlos, dinámica que permitiría al Estado defenderse de sujetos peligrosos a través de medidas de seguridad.

${ }^{104}$ Vid. SANZ MORAN, "Sobre la justificación”, cit. nota n 59, p. 974, Nota 24; ZIFFER, Medidas de seguridad, cit. nota $\mathrm{n}^{\circ} 15, \mathrm{p} .77$.

${ }^{105}$ En un sentido similar se manifestó en España CASABÓ RUIZ ("El fundamento", cit. nota n 71 , pp. 58 y ss), con un desarrollo más incipiente que tiene el valor de ser completamente autónomo. Este autor, luego de adherirse a la crítica al positivismo y objetar los excesos a que llevan los intentos de corrección moral del individuo, asume que la restricción de las libertades individuales sólo puede encontrar justificación en la medida en que diga relación con daños que se hubieren causado a terceros o a la sociedad, colocando el acento en una base liberal. Concluye de esta forma que solo se justifica una medida de seguridad, al igual que en la legítima defensa, cuando nos encontremos en presencia de un auténtico ataque o agresión o en los casos en "que el peligro de esta agresión o ataque a la sociedad es tan evidente que no resulta un juicio temerario la idea del ataque". Frente a ello la medida de seguridad cumple la función de evitar o impedir dicho daño poniendo con ello el acento en su necesidad, en el hecho de que pueda ser calificada como una herramienta defensiva y en la presencia de un peligro de afectación que califica como evidente. CASABÓ RUIZ, "El fundamento", cit. nota $n^{\circ} 71$, p. 58 .

${ }^{106}$ Una orientación similar desarrollan Bottoms y Brownsword (en BOTTOMS, Roger/BROWNSWORD, A.E., "The dangerousness debate after the Floud report", British Journal of Criminology (Julio 1982), pp. 229 y ss.) en el contexto que propone el derecho británico, bajo una perspectiva de la proporcionalidad centrada en el derecho de la víctima potencial a no ser gravemente lesionada. Critica en VON HIRSCH, Andrew, "La prolongación de la pena para los delincuentes peligrosos", en: CID/LARRAURI (edits.): La delincuencia violenta: ¿Prevenir, castigar o rehabilitar?, Valencia: edit. Tirant lo Blanch, 2005, pp. 194-5. También puede apreciarse una propuesta semejante en las actuales aportaciones de GRACIA MARTIN ("Sobre la legitimidad", cit. nota ${ }^{\circ} 60$, pp. 988-9), refiriéndose en forma expresa al estado de necesidad y que no hemos incluido en este lugar pues el contenido concreto que propone para el desarrollo obedece casi de manera íntegra al contenido más tradicional de la tesis del interés preponderante (Vid. p. 997).
} 
MALDONADO, Francisco. “¿Se puede justificar la aplicación copulativa de penas y medidas de seguridad? Estado actual de las posiciones doctrinales

que buscan dicho objetivo".

En todos estos casos el punto de partida es la formulación de una profunda crítica al ejercicio ponderativo. Schunemann por ejemplo no se limita a destacar objeciones centradas en el utilitarismo presente en la tesis tradicional, sino que además se ocupa de explicar por qué las faltas de certeza que dicho planteamiento propone constituyen una cuestión estructural. Asume que la proporcionalidad se desarrolla en base a una dinámica "tópica" que se encuentra "embotada en la práctica", que se rige por parámetros que a fin de cuentas son del todo aleatorios y que no le permiten proponer bases rígidas o estables para acometer la tarea de valorar intereses con pretensiones de validez general. ${ }^{107}$

Se trata por ello de un mecanismo que, naturalmente, carece de capacidad o aptitud de concreción. Concluye sobre esa base que "la requerida legitimación de las medidas sólo puede hallarse, por tanto, en el <estado de necesidad para los bienes jurídicos>", criterio que, según entiende, proporciona supuestos más rígidos y concretos, ya sea por centrarse en contenidos más asentados (desarrollados) como también por el hecho de que en ellos se evita recurrir a la subjetividad que caracteriza a la ponderación de valores. ${ }^{108}$

\subsubsection{Valoración y crítica.}

No parece que la recepción de esta orientación haya sido positiva y con buenas razones. La necesidad de reaccionar frente a la eventualidad del daño y la necesidad de defensa (que la transforman en legítima) suponen una agresión, y una probabilidad de concreción que suele reflejarse en una exigencia de actualidad o inminencia, contenidos que difícilmente pueden acreditarse en los supuestos propios de una medida de seguridad. ${ }^{109} \mathrm{Y}$ es que no estamos frente a la urgencia que es propia de este tipo de situaciones de necesidad y que, por sí mismas, justifican reaccionar. A partir de ello una diversidad de autores (entre ellos Frisch y Jakobs) descartan de plano la utilidad del criterio propuesto, en cuanto se trata de una aproximación que se mueve en planos completamente diversos a los que ofrecen los supuestos que se pretenden regular. ${ }^{110}$

\footnotetext{
${ }^{107}$ Interesante resulta apreciar que ni siquiera en Estados Unidos (donde destaca el desarrollo de criterios jurisprudenciales en el funcionamiento del sistema de justicia criminal) es posible encontrar fiabilidad a este respecto. Vid. CASTIÑEIRA PALOU, María Teresa/RAGUÉS I VALLĖS, Ramón, "Three Strikes. El principio de proporcionalidad en la jurisprudencia del Tribunal Supremo de los Estados Unidos", $R D P C, 2^{\text {a }}$ época, $\mathrm{N}^{\circ} 14$ (2004), pp. 62 a 79), quienes arriban a dicha conclusión a partir del análisis de jurisprudencia que precisamente aborda una cuestión próxima, relativa a si es posible ir mas allá de la proporcionalidad por el hecho a propósito de las denominadas "Leyes de Three Strikes".

${ }^{108}$ En el mismo sentido se pronuncia JAKOBS (Derecho Penal, cit. nota ${ }^{\circ}$ 77, pp. 39: "Más concreta es la propuesta de concebir las medidas de seguridad desde consideraciones propias de la legítima defensa") más allá de no compartir la propuesta de fondo por otros motivos.

${ }^{109}$ FRISCH, "Las medidas de corrección". cit. nota n 13, p. 20; ZIFFER, Medidas de seguridad, cit. nota n 15, p. 77.

${ }^{110}$ Para FRISCH ("Las medidas de corrección", cit. nota $n^{\circ}$ 13, p. 21) "No es lo mismo un delito que se espera que ocurra alguna vez que una agresión actual". Por su parte para JAKOBS (Derecho Penal, cit. nota $\mathrm{n}^{\circ} 77$, p. 39) en "la imposición de medidas de seguridad falta la urgencia propia de un ataque actual" con lo que "fracasa materialmente el paralelismo con la legítima defensa". Este autor destaca además que en estos casos hay efectivamente un paralelo posible de establecer pero que es distinto, emanado de que en la actuación en legítima defensa concurre igualmente un tratamiento basado en una despersonalización del agresor. Entiende en todo caso que ellas se motivan en lo que define como "abolladuras" transitorias de la personalidad, destacando que no se trata de una cuestión permanente, como la que se motiva en torno a las
} 


\section{Polit. crim. Vol. 6, № 12 (Diciembre 2011), Art. 5, pp. 387 - 447. [http://www.politicacriminal.cl/Vol_06/n_12/Vol6N12A5.pdf]}

Pero además hay que tener en cuenta que los supuestos de dicha tesis aparecen confiados a la afirmación de un pronóstico de peligrosidad, y particularmente a su fiabilidad y contundencia, lo que tampoco parece compatible con la falta de certezas que lo caracterizan. Concebir la peligrosidad como una agresión no puede por ello afirmarse sino es en base a una ficción o, si se prefiere, de una presunción, con lo cual todo este esquema no pasaría de ser un desarrollo argumentativo, ${ }^{111}$ funcional a las decisiones del legislador. $^{112}$

Se agrega finalmente una objeción de carácter general: la pretensión de equiparar estas intervenciones con las situaciones de necesidad o de defensa yerra al igualar el desarrollo de una función pública de protección con una dinámica de justificación que es propia del desarrollo individual en el actuar cotidiano, supuestos que no son en modo alguno comparables. ${ }^{113}$ Lo central es que en el primer caso debe recurrirse a principios que sean propios del actuar de la autoridad, mientras que el segundo se rige precisamente por la urgencia o inminencia que hace necesaria la actividad (y que, además, no existe en este caso en particular). ${ }^{114}$

Además de todo ello es claro que la tesis encuentra sus orígenes en la sostenida falta de claridad y desarrollo que aqueja a los contenidos planteados para resolver la fórmula que propone la tesis del interés preponderante. De ahí que suponga una especie de confianza en que esta fórmula llegue a contar con criterios más claros, elaborados y asentados en torno a las instituciones que permiten resolver de forma más objetiva la presencia de una situación de necesidad. Sin embargo se obvia de plano que dicho ejercicio también supone el desarrollo de una ponderación, tanto en los caracteres de la situación de necesidad como en la valoración de la necesidad de la reacción. Lo confirma el solo hecho de que los valores, bienes o intereses comprometidos también constituyen un elemento a considerar en dichas valoraciones. Al respecto son conocidas las indeterminaciones que aquejan al desarrollo de la noción y acreditación de la peligrosidad, siendo aun menos claro el contenido que permite determinar cuando la reacción sería necesaria frente a una inminencia que no existe en la realidad.

medidas de seguridad (JAKOBS, Günther, "Coacción y personalidad. Reflexiones sobre una teoría de las medidas de seguridad complementarias a la pena", InDret 1 (2009), pp. 6 y 7).

${ }^{111}$ ZIFFER, Medidas de seguridad, cit. nota ${ }^{\circ} 15$, p. 77 (quien lo califica al argumento como "metafórico").

${ }^{112}$ A este respecto conviene recordar que la idea de centrar las intervenciones penales en torno a conceptos como la legítima defensa (de la sociedad) son antiguas y no muy desvinculadas del utilitarismo. Así, en las perspectivas del positivismo subyace una explicación biologicista de la sociedad que lleva a concebirla como organismo autónomo, justificándose a partir de esta base la potencial eliminación o anulación del individuo para fines de conservación social, idea de autodefensa que es asumida en ello como una reacción natural, casi instintiva de parte del colectivo. Sobre el fundamento de fondo radicado en la propia conservación de la sociedad ("la necesidad de conservación domina tanto a un organismo animal como a un organismo social."), referido a la lógica positivista (que concibe el universo como un gran engranaje biológico, funcional).

${ }^{113}$ FRISCH, "Las medidas de corrección", cit. nota $n^{\circ} 13$, p. 21 . Al respecto JAKOBS (Derecho Penal, cit. nota $n^{\circ} 77$, p. 39) señala: "la legítima defensa no se ajusta precisamente a la acción estatal de defensa" (el subrayado es nuestro).

${ }^{114}$ Robles Planas se hace cargo en concreto de este punto. Para ello califica como legítima la pretensión que demanda hacerse cargo de la peligrosidad criminal en función a alcanzar mayores niveles de seguridad, asumiendo que se mueve dentro del campo de opiniones y deseos propios de una sociedad democrática. En el mismo sentido pueden entenderse las reflexiones de Frisch que acabamos de comentar. 
MALDONADO, Francisco. “¿Se puede justificar la aplicación copulativa de penas y medidas de seguridad? Estado actual de las posiciones doctrinales

que buscan dicho objetivo".

\subsection{Reformulación: la respuesta no penal.}

\subsubsection{Fórmula propuesta.}

Estas perspectivas han sido reorientadas en la actualidad por Robles Planas. Dicho autor asume como premisa el que las medidas de seguridad no forman parte del Derecho penal, ${ }^{115}$ constituyendo reacciones con objetivos y formas de interacción diversas que, por ello, deben ser integradas en una rama del derecho autónoma destinada al tratamiento de la peligrosidad criminal. En dicho contexto las concibe como formas de intervención subsidiarias y focalizadas, dirigidas a "supuestos excepcionales en los que la peligrosidad actual de una persona supusiera una amenaza inminente, grave y suficientemente concreta y probable" y cuya legitimidad emanaría directamente desde el orden constitucional. ${ }^{16}$ Son dichas condiciones las que llevan naturalmente a que su eventual justificación deba analizarse a partir de "la lógica del estado de necesidad (defensivo)" que puede incluso llegar a "alcanzar la privación de libertad como mal necesario para conjurar el peligro", acotada "no obstante, a su empleo aislado -como toda intervención- en "situación de necesidad". ".117

Se trata en el fondo de una actividad de mera contención que pareciera demandar una aplicación breve, estrictamente circunscrita al marco en que se mantenga el "estado de riesgo inminente", lo que permitiría a este autor salvar adecuadamente los problemas de inmediatez y asertividad en el diagnóstico y en los riesgos comprometidos. ${ }^{118}$ Además, en dicho esquema se refuerza la idea de que la privación de libertad se reserva para situaciones muy excepcionales, privilegiando intervenciones de terapia, vigilancia o seguimiento especializado (objetando el desarrollo que a este respecto ha tenido lugar a propósito de conceptos como el de libertad asistida). ${ }^{119}$

\subsubsection{Valoración crítica.}

No obstante todo ello no parece que el objetivo propuesto se logre. El problema está en que en la perspectiva de Robles Planas los conceptos de inminencia y de necesidad no son valorados en forma estricta. Se evidencia en cuanto considera la posibilidad de extender las

\footnotetext{
${ }^{115}$ En el mismo sentido GUZMAN DALBORA, La pena y la extinción, cit. nota n 4, pp. 63 y ss.; JAKOBS, Derecho Penal, cit. nota n ${ }^{\circ}$ 77, p. 41.

${ }^{116}$ Robles Planas por ejemplo destaca que las garantías fundamentales no son algo privativo del Derecho penal y que el hecho de confiar o tomar en serio el Estado de derecho se demuestra precisamente en la autonomía que a este respecto debe reconocerse al orden constitucional (" $<$ Sexual Predators $>$ ", cit. nota $n^{\circ} 7$, p. 19, Nota 61). En el mismo sentido LASCURAIN SANCHEZ, Juan Antonio, "Por un derecho penal solo penal: derecho penal, derecho de medidas de seguridad y derecho administrativo sancionador", en: JORGE BARREIRO (edit.): Homenaje al profesor $d r$. Gonzalo Rodríguez Mourullo, Madrid: Edit. Thomson/Aranzadi, 2005, p. 589, quien además lo reitera numerosas veces a lo largo del texto (p. ej. pp. 610, $614,615)$.

${ }^{117}$ ROBLES PLANAS, Derecho Penal, cit. nota ${ }^{\circ}$ 7, p. 20.

${ }^{118}$ Lo dicho no se traduce en una menor exigencia diagnóstica pues Robles Planas demanda expresamente una elevada fiabilidad en el pronóstico ("no basta la mera posibilidad") a ser desarrollada en un marco especializado que a su vez debe configurarse a partir de garantías liberales.

${ }^{119}$ ROBLES PLANAS, Derecho Penal, cit. nota n ${ }^{\circ}$, p. 20.
} 


\section{Polit. crim. Vol. 6, № 12 (Diciembre 2011), Art. 5, pp. 387 - 447. [http://www.politicacriminal.cl/Vol_06/n_12/Vol6N12A5.pdf]}

medidas de intervención por tiempos prolongados a partir de lo que considera es una "continuada presencia del peligro inminente, grave y determinado". ${ }^{120}$ Ello revela que en el fondo está pensando en un contenido de base o presupuesto que corresponde a un determinado grado de valoración de la peligrosidad lo que materialmente constituye un estado o condición de carácter permanente, ${ }^{121}$ renunciando por ello a la idea de que la medida opera en función de una situación que lleve a fundar la necesidad de reaccionar. De esta forma parece claro que ninguna de las cuestiones críticas antes planteadas se ven solucionadas en forma efectiva pues en el fondo el único elemento que sirve como garantía a la valoración de la necesidad de intervenir es el apego que este autor plantea respecto a la estricta subsidiariedad y excepcionalidad, careciendo el planteamiento (en su estado actual) de parámetros concretos que permitan valorar ambos supuestos.

Por otro lado, el recurso a la situación de necesidad se funda en este planteamiento en la afirmación de que las medidas de seguridad no forman parte del Derecho penal, elemento que resulta determinante para su consideración y que se afirma a partir de la propia naturaleza, funciones y características de los presupuestos de las medidas y en las que correlativamente caracterizan la pena. El punto es que también este supuesto amerita reparos en cuanto las relaciones entre ambas herramientas y su conexión en torno al hecho punible genera efectos materiales que se producen con total independencia de cuales sean las etiquetas o sistematizaciones que las describan o caractericen o el lugar o rama del derecho en que se ubiquen. ${ }^{122} 123$

Lo primero a tener presente es que la idea de independizar este ámbito de las esferas del Derecho penal no es nueva, a pesar de lo cual pena y medida conservan en la actualidad una serie de vínculos e interacciones que no pueden desconocerse y que provienen del hecho de que comparten objetivos, contenidos y presupuestos.

Lo segundo a destacar es que resulta bastante discutible que esta separación presente como ventaja el favorecer la identificación y el desarrollo de principios autónomos de legitimación para las medidas de seguridad, como postula Robles Planas. Hay que tener en cuenta que las medidas de seguridad se han mantenido dentro del Derecho penal sin que ello haya significado para la mayoría que dejen de ser concebidas bajo parámetros propios de legitimación. Pero también es relevante reiterar que existen puntos de conexión que impiden que en este plano se produzca una distancia considerable entre ambas

\footnotetext{
${ }^{120}$ Idem.

${ }^{121}$ Vid JAKOBS, “Coacción y personalidad", cit. nota $n^{\circ} 110$, pp. 6 y 7.

${ }^{122}$ Es efectivo que parte de los supuestos de las medidas de seguridad se muestran del todo ajenos a la lógica de la intervención penal. No obstante, cuando se utiliza este recurso para hacer frente a la actividad delictiva dicha independencia natural se desvanece. Así se explica que el internamiento civil de un enajenado o de un menor abandonado de corta edad genere lecturas diversas según si va acompañado o no de una hipótesis delictiva. De esta forma, la concurrencia de una hipótesis delictiva entre los presupuestos que justifican la aplicación de una medida altera inevitablemente el sentido de su uso, generando efectos tangibles y simbólicos que no pueden ser desconocidos. (SILVA SÁNCHEZ, “Medidas de seguridad”, cit. nota $n^{\circ} 24$, pág. 890).

${ }^{123}$ En cierta forma lo reconoce GUZMAN DALBORA (La pena y la extinción, cit. nota $\mathrm{n}^{\circ}$ 4, p. 101) a la hora de estimar preferible que sea el criminalista quien asuma el tratamiento de las medidas de seguridad para dotarlas de un marco de garantías equivalentes a las que propone el Derecho penal.
} 
MALDONADO, Francisco. “¿Se puede justificar la aplicación copulativa de penas y medidas de seguridad? Estado actual de las posiciones doctrinales

que buscan dicho objetivo".

herramientas, pues en ambos casos estamos frente a tratamientos coactivos o forzosos, restrictivos de derechos fundamentales y que (al menos en parte) consideran objetivos de prevención especial. ${ }^{124}$ De esta forma se trata de una ventaja del todo aparente y que no se hace cargo en modo alguno del plano de lo material. ${ }^{125}$ Por lo mismo tampoco es efectivo el que con ello se eviten efectos que son calificados como una contaminación del derecho penal y que provendrían precisamente de la diversa naturaleza y caracterización de ambas formas de reacción.

No queremos con ello desconocer la presencia de efectos preventivos en el Derecho penal de la pena, sino de tener en cuenta que ellos se producen con total independencia de la pertenencia formal de las medidas de seguridad al ámbito del Derecho penal o a un área del derecho independiente, pues, donde se ubique, la medida de seguridad va a producir efectos en la satisfacción de los objetivos preventivos e incluso en el ámbito del sentido (mas allá de su orientación empírica o cognitiva) los que en modo alguno se van a alterar en base a cuestiones de organización o sistematización formal. ${ }^{126}$

Finalmente, tampoco parece que esta ventaja se refleje en concreto en las aportaciones de Robles Planas quien no logra sobre esa base avanzar en una mejor y mayor concreción de los presupuestos de legitimación de las medidas. Y es que no parece haber mucha claridad en torno a la caracterización independiente que se postula, lo que de hecho debiera ser el motivo principal para justificar las ventajas de la separación. En concreto se limita a

\footnotetext{
${ }^{124} \mathrm{Si}$ bien ya lo hemos dicho hay que tener en cuenta a este respecto que ambas reacciones son aceptadas como formas de reacción frente al delito, proponiendo este solo supuesto una serie de condicionantes de legitimación que pasan a ser comunes a pena y medida. Sobre esta base autores que sustentan definiciones de base similares a las de Robles Planas explican por qué pena y medida presentan coincidencias en los principios que concurren a su legitimación, a pesar de su diversa naturaleza. Vid. AZNAR LOPEZ, Manuel, Internamientos civiles y derechos fundamentales de los usuarios de centros sanitarios, sociales y sociosanitarios, Granada: Edit. Comares, 2000, pp. $77,83,85$ y ss., y 94 y ss.

${ }^{125}$ No se trata por ello solo de que resulte ventajoso o deseable una gestión conjunta de ambas reacciones por razones de economía procesal o de coordinación de las actuaciones públicas (motivo inicialmente tenido en cuenta por Stoo como argumento fundamental) existiendo razones que parecen mas bien exigir una unidad en torno a una misma dinámica procedimental por las coincidencias materiales y en los objetivos de cada herramienta. SILVA SÁNCHEZ, “¿Medidas de seguridad”, cit. nota n²4, p. 890; SANZ MORAN, Las medidas de corrección, cit. nota $\mathrm{n}^{\circ} 10, \mathrm{p} .43$.

${ }^{126}$ Como indican POLAINO NAVARRETE/POLAINO ORTS (“¿Medidas de seguridad inocuizadoras para delincuentes peligrosos? Reflexiones sobre su discutida constitucionalidad y sobre el fundamento y clases de las medidas de seguridad", $A P \mathrm{~N}^{\circ} 38$ (2001), p. 921) concebir a las MSC como una instancia ajena al derecho penal (en relación a la concepción de Jakobs) no hace desaparecer el nexo que existe con la pena en torno a que forman una comunidad tutelar de bienes y preventiva. Ello confirma que los efectos señalados emanan de los presupuestos de la pena y de la medida, con lo cual afectarán a ambas donde quiera que se la pretenda ubicar. La censura va estrechamente asociada a la culpabilidad y la necesidad de estabilidad simbólica al hecho delictivo y nada de eso va a cambiar porque se modifiquen las etiquetas o radicaciones formales de ambos institutos. La sociedad seguirá encontrando confianza en el internamiento del enajenado aunque este se desarrolle en un hospital psiquiátrico, sin que en uno y otro caso (es decir, dentro o fuera del Derecho penal) se le dirija un reproche. En ambos, se lo identificará como causa o factor de riesgo, esto es se lo asociará al hecho delictivo que se espera que cometa precisamente en atención al que ya ha cometido. Y lo mismo sucederá con el culpable peligroso. De ahí que la reacción estatal cumpla una función de solución del conflicto, siempre, y cualquiera sea el ropaje bajo el cual se disponga a realizarlo.
} 


\section{Polit. crim. Vol. 6, No 12 (Diciembre 2011), Art. 5, pp. 387 - 447. [http://www.politicacriminal.cl/Vol_06/n_12/Vol6N12A5.pdf]}

destacar que en la actualidad hay aportes suficientes e importantes que permiten emprender la tarea de configurar los límites propios del derecho de la peligrosidad. ${ }^{127}$

\section{La medida de seguridad como reacción "merecida".}

Desde antiguo un grupo diverso de autores ha buscado el fundamento de esta forma de intervención en condicionantes radicadas en el destinatario de la medida, siendo una constante el pretender de esta forma evitar la crítica de que la imposición de medidas de seguridad instrumentaliza al individuo. ${ }^{128} \mathrm{La}$ idea de fondo es que se puede atribuir al propio individuo el peso de la inseguridad que proviene de la peligrosidad diagnosticada en su contra, debiendo por ello ser éste quien asuma las consecuencias que de ello se derivan. Desde estas perspectivas la medida no solo sería una reacción que la sociedad necesita, sino además una consecuencia que el individuo "merece".

Presentan en común la ventaja de desvanecer los problemas que plantea el ir más allá de la culpabilidad individual, radicando las dificultades propias en el problema de compatibilizar e integrar la fuente material del merecimiento que habilita a la medida con el que plantea dicho concepto para fundar la imposición de la pena.

\subsection{Precedentes: la recuperación moral del individuo (Welzel).}

\subsubsection{Fórmula propuesta.}

Originalmente se buscó identificar una justificación para la imposición copulativa de medidas de seguridad en contenidos de carácter ético-social presentes en el sujeto a partir de la afirmación de un deber del Estado referido a procurar la recuperación "moral" y "social" de ciertos individuos. La idea es sustituir la sola referencia a la utilidad social, en tanto instrumentalizadora del individuo, por la utilidad personal de quien padece la carencia, abordando paternalistamente la necesidad de promover la recuperación de la "autonomía o competencia social perdida". ${ }^{129}$ Las referencias a este respecto suelen remitir a Welzel cuyo punto de partida radica en sostener que el diagnóstico de la peligrosidad criminal supone una insuficiencia en las capacidades de desarrollo y desenvolvimiento social (normales, suficientes o necesarias) del individuo. Sobre esta base se sostiene que aquellos que presentan una tendencia más o menos segura a la comisión del delito padecen

\footnotetext{
127 Lascurain Sánchez avanza un poco más destacando diferencias concretas en la configuración de la proporcionalidad y en las (menores) exigencias (en materia de determinación) que conlleva la legalidad.

${ }^{128}$ Históricamente estos lineamientos se alzaron en contra del utilitarismo de la escuela positiva, recobrando fuerza en la actualidad en base a las debilidades y críticas de la tesis del interés preponderante (CASABÓ RUIZ, "El fundamento", cit. nota $n^{\circ} 71$, p. 54). Un claro ejemplo de esta conexión se aprecia en la evolución del planteamiento de Silva Sánchez, quien, a pesar de sostener hasta hace poco una óptica centrada en el dualismo flexible se inclina en la actualidad por buscar un camino alternativo en la lógica del actuar precedente del infractor reiterante. Vid. al respecto entrevista contenida en http://www.dpenal.cl/multimedia/ [Última visita 27.05.11].

${ }^{129}$ Veremos mas adelante que otros autores se concentran más bien en una valoración de las causas o motivos de la incapacidad social diagnosticada en tanto es posible identificar argumentos de mérito claros para intervenir en aquellos casos en que se afirma una cuota de responsabilidad personal en su génesis (el actuar precedente que causa el hábito o tendencia criminal) en el hecho de acreditar que corresponde más bien a una decisión personal de apartarse del marco de respeto del derecho (rebeldía o ánimo contrario a derecho).
} 
MALDONADO, Francisco. “¿Se puede justificar la aplicación copulativa de penas y medidas de seguridad? Estado actual de las posiciones doctrinales

que buscan dicho objetivo".

un déficit para desempeñarse normalmente en sociedad, hecho que los coloca en una posición especial que habilita a que el Estado asuma el desafío de recuperarlos. ${ }^{130}$

Welzel elabora su propuesta a partir de dos premisas fundamentales: i) la persona es un ente moral que detenta libertad; y ii) el Estado tiene el deber de dotar a los individuos de condiciones básicas para su desenvolvimiento y desarrollo social a fin de posibilitar el ejercicio de la libertad. A partir de ello asume que la interacción ético-social requiere de capacidad de comportarse conforme a las normas, de forma tal que sólo quien puede dejar conducirse por ellas puede participar en la vida social. Con ello, postula que la libertad social o externa se funda y depende en la libertad interior, que es un concepto equivalente a la capacidad individual de autodeterminación moral. Quienes carezcan de ella, ya sea por no tener "capacidad de autodeterminación moral" o por "carecer de la fuerza de voluntad suficiente en razón a hábitos o vicios" adquiridos, no pueden por ello aspirar a una plena libertad social, ni reclamarla. ${ }^{131}$

Con ello Welzel entiende que quien ha adquirido hábitos, malas inclinaciones, vicios o costumbres que los apartan del respeto de las normas ético-sociales (el sujeto peligroso), detenta una falencia en la capacidad para regirse por ellas, concluyendo que no gozan de una libertad social completa lo que puede suceder a pesar de que se trate de sujetos imputables. El Estado tendría el deber de asistirlos a través de un tratamiento curativo o educativo -alternativas que a estos efectos detentan idéntico sentido- con el fin de contribuir a la recuperación de su "plena dignidad". ${ }^{132}$ Esto último constituiría un segundo momento en la justificación que pasaría por ello a estar conformada por dos componentes: por un lado se identifica detrás de la carencia un momento de interés personal (que le permite a Welzel relativizar el interés social en la prevención delictiva): ${ }^{133} \mathrm{y}$, por otro lado,

${ }^{130}$ El planteamiento pareciera abandonado formalmente para casos de plena imputabilidad. En España lo sostiene Rodríguez Mourullo (inicialmente en 1965, "Significado político", cit. nota $\mathrm{n}^{\circ}$ 86, pp. 781 y ss. y luego en 1974, "Medidas de seguridad", cit. nota ${ }^{\circ}$ 24, pp. 367-8) siendo también defendido en su momento por Jorge Barreiro (1976, Las medidas de seguridad, cit. nota $\mathrm{n}^{\circ}$ 85, pp. 82 y ss.) quien recientemente (2001, "Crisis actual", cit. nota ${ }^{\circ}$ 85, p. 153 y en 2005, "Reflexiones sobre la compatibilidad", cit. nota ${ }^{\circ} 13$, pp. 566-7) adhiere a la tesis del interés preponderante. También es asumido como base de justificación parcial en CEREZO MIR (Curso de derecho Penal español, cit. nota $n^{\circ} 13$, pp. 41-2) y GRACIA MARTIN (“Culpabilidad y prevención", cit. nota n ${ }^{\circ} 11$, p. 439 y 440) para los casos de inimputabilidad.

${ }^{131}$ RODRÍGUEZ MOURULLO, "Significado político", cit. nota n 86, p. 784.

${ }^{132}$ La incompetencia detectada manifiesta un déficit, y por ello desigualdad, haciendo necesario compensarla (GONZALEZ CONTRÓ, "Paternalismo jurídico y derechos del niño", Isonomía № 25 (2006), pp. 111 y 122 y ss.). La vinculación con el carácter necesario de la intervención hace que este razonamiento sea propio de la categoría denominada derecho-deber en que se estima concurrente, además del propio beneficio del afectado, un interés propio de quien resulta obligado (sobre ello PECES BARBA, Curso de Derechos Fundamentales, Universidad Carlos III de Madrid, 1999, pp. 461-2). Dicha construcción permite superar una perspectiva meramente asistencialista de la intervención que no resultaría tolerable.

${ }^{133}$ ROCA AGAPITO, El sistema de sanciones, cit. nota ${ }^{\circ}$ 85, p. 380 destaca que por ello la justificación se desarrolla tanto desde el punto de vista social como desde la perspectiva individual, lo que parece correcto. El punto es que en Welzel dicho interés colectivo no se ubica en referencia a la prevención del delito sino que se muestra perfectamente coincidente con el interés de recuperación del individuo. Y parece claro que procura intencionalmente desvincular por completo el argumento de toda base naturalística o externa al sujeto (CASABO RUIZ, "El fundamento", cit. nota $n^{\circ}$ 71, p. 56) demostrando un exagerado interés por lograr que en su contenido no haya ningún componente que se aproxime al intereses de utilidad social. Ello hace que 


\section{Polit. crim. Vol. 6, No 12 (Diciembre 2011), Art. 5, pp. 387 - 447. [http://www.politicacriminal.cl/Vol_06/n_12/Vol6N12A5.pdf]}

se agrega, como objetivo específico la "recuperación moral del individuo", concepto equivalente a su dignidad y a su personalidad. Este último aspecto configuraría una garantía política, descartándose sobre esa base la legitimidad de medidas que, por su contenido o finalidad, atenten (formal o tácticamente) contra la "personalidad moral del individuo" o que afecten su dignidad, dirigiéndose la atención a la proscripción de las formas de intervención meramente inocuizadoras (sea que lo pretenda o que simplemente lo genere como consecuencia). ${ }^{134}$

\subsubsection{Valoración crítica.}

Este planteamiento debió enfrentar numerosas observaciones críticas que no le permitieron una amplia acogida y que culminaron con su abandono formal, mas allá que en tiempos recientes se hayan retomado algunos de sus contenidos y que permanezca vigente en parte de la doctrina para legitimar medidas aplicables a inimputables.

Hay que tener en cuenta en primer lugar que la argumentación de Welzel coincide con la lógica de las intervenciones estatales conocida como paternalismo, que esencialmente postulan la legitimidad de actuaciones coactivas regidas y justificadas por orientarse en torno a objetivos dirigidos a favorecer al propio individuo que las padece y que se imponen con absoluta prescindencia de su voluntad. La idea de base es que la natural debilidad de voluntad del individuo hace que en determinados casos no se encuentre en posición de tomar decisiones conforme a su propia autodeterminación, en cuanto ello le podría generar consecuencias perjudiciales e indeseadas, debiendo por ello el Estado limitar su capacidad de resolución de forma obligatoria a través de la atribución de una cuota de incapacidad. ${ }^{135}$

dirija la atención hacia el sujeto de manera un tanto forzada, buscando el componente ético faltante lo más lejos posible del interés general de la colectividad en la prevención del delito. De hecho, se hace cargo de minimizar su consideración, calificándolo expresamente como un objetivo o función secundaria, del todo deseable o positiva, pero que no cumple papel alguno en la justificación y menos aun en forma determinante.

${ }^{134}$ CASABO RUIZ ("El fundamento", cit. nota n 71, p. 56); ROCA AGAPITO (El sistema de sanciones, cit. nota $n^{\circ} 85$, p. 383). En dichos casos la intervención se apartaría de la finalidad de recuperación moral que debe orientarla y justificarla, toda vez que no resulta posible asumir que restablezcan la personalidad, en cuanto se limitan simplemente a neutralizar determinados aspectos o componentes de la misma. Las referencias expresas de Welzel a este respecto se dirigen a la medida de castración o esterilización prevista en la regulación alemana de 1933 que inaugura en dicho país el régimen de medidas de seguridad e introduce formalmente la idea de peligrosidad en el sistema positivo. (Derecho Penal Alemán, cit. nota ${ }^{\circ}$ 86, p. 289). En el mismo sentido RODRÍGUEZ MOURULLO, "Medidas de seguridad", cit. nota n 24, p. 784.

${ }^{135}$ Bajo dichos postulados se acepta la legitimidad de que el Estado adopte medidas con prescindencia de la voluntad o aceptación de quien debe llevarlas a cabo si a través de ella se logra evitar que el individuo se cause un daño a sí mismo (se busca "proteger a la gente de si misma"). Se trata básicamente de no dar lugar a la libre elección del sujeto en determinadas situaciones, en atención a que no pude afirmarse que se comportará a partir de una elección realmente razonada, evitando de esa forma que un fallo (que pasa a ser considerado probable) en sus propias determinaciones llegue a perjudicarle. De ahí su vinculación más directa con casos en que se sostiene una carencia general en las capacidades básicas para administrar razonablemente la voluntad o la libertad. Con sus respectivas diferencias y matices los elementos descritos a modo general se comprenden en los conceptos expuestos por ALEMANY, Gregorio, El concepto y la justificación del paternalismo, Edición digital de Alicante, Biblioteca Virtual Miguel de Cervantes, 2005 (http://www.cervantesvirtual.com/), pp. 444-5; GONZALEZ CONTRÓ, "Paternalismo jurídico", cit. nota n 132, p. 105; CAMPS, Victoria, "Paternalismo y bien común", DOXA N 5 (1988), p. 195; GARZON VALDES, Ernesto, “¿Es éticamente justificable el paternalismo jurídico?”, DOXA N 5 (1988), p. 155; RAMIRO AVILÉS, Miguel Angel, “A vueltas con el paternalismo jurídico”, Revista Derechos y Libertades 
MALDONADO, Francisco. “¿Se puede justificar la aplicación copulativa de penas y medidas de seguridad? Estado actual de las posiciones doctrinales

que buscan dicho objetivo".

El punto está en que a estas alturas resulta claro que este tipo de pretensiones, dirigidas a la corrección del individuo para su propio beneficio, encierran riesgos de consideración para el respeto a los espacios de ejercicio legítimo de la autonomía del individuo que impone el orden constitucional.

En primer lugar hay que tener en cuenta que la pretensión de corrección lleva a una intervención que debe ser orientada exclusivamente a la superación de la falencia que le sirviere de base o presupuesto, lo que conlleva (entre otras consecuencias) necesariamente que sus objetivos se concentren en el interés del propio afectado. La presencia de un interés externo o ajeno a la recuperación o protección del individuo incorpora un elemento distractivo o distorsionador que no solo desvirtúa los objetivos pretendidos (y con ello la propia argumentación) sino que solidifica la percepción de que estamos frente a una construcción de corte retórico que encubre un objetivo real diverso. ${ }^{136}$

Este contenido ubica a la orientación paternalista en un contexto completamente ajeno a los caracteres más elementales del sistema penal, lo que resulta evidente si tenemos en cuenta que las reacciones penales son concebidas en la actualidad como un mal que debe padecer el infractor y por el indiscutible fin social que persigue el sistema (prevención del delito). ${ }^{137}$ En efecto, en este planteamiento el ideal de "recuperación del individuo" se encuentra mediatizado por el interés de la sociedad en tratar lo que se considera es un déficit presente en el infractor, elemento que debilita sensiblemente la potencialidad autónoma del argumento como fuente de legitimación. ${ }^{138}$

número 15, Época II (Junio 2006), pp. 211 a 256, p. 213; DWORKIN, Gerald, "El paternalismo", en: BETEGON/DE PARAMO (Dirs.), Derecho y Moral. Ensayos analíticos, Barcelona: Edit. Ariel., 1990, p. 151.

${ }^{136}$ Es evidente que no se exige una dirección exclusiva hacia tales fines pues resulta muy complejo encontrar casos "puros" (por denominarlos de alguna forma) pues siempre los procesos decisorios (y particularmente los legislativos) son consecuencia de un conjunto de motivos y razones (DWORKIN, "El paternalismo", cit. nota $\left.\mathrm{n}^{\circ} 135, \mathrm{p} .148\right)$. Lo que sí se exige en toda justificación paternalista es una inequivoca orientación hacia la protección de quien resulta coaccionado.

${ }^{137}$ En este sentido ZIFFER, Medidas de seguridad, cit. nota ${ }^{\circ} 15$, pp. 87 y ss. Debemos reconocer que también se ha sostenido la aptitud del sistema penal como medio de perfeccionamiento del individuo a partir de corrientes denominadas moralistas que han pretendido establecer imperativamente en la sociedad parámetros de comportamiento considerados valiosos, recurriendo a la pena como medio educativo de inculcación de las perspectivas que los sustentan. No es que la pena sea vista como un bien, sino que éste radica en el efecto disuasorio que persigue la proscripción: se trata de limitar la voluntad en aquello que es considerado perjudicial para la personalidad moral del sujeto. De ahí que el centro de la proscripción radique en lo que se considera un beneficio para el mismo. La diferencia con la actuación a través de medidas paternalistas radica exclusivamente en la intensidad de la interferencia en la autonomía del individuo que propone una y otra dinámica. Así, mientras la penalización moralista se limita a disuadir al sujeto para apartarlo de aquello que le provoca un perjuicio moral, respetando formalmente el reconocimiento de su autonomía externa y general (si bien no de fondo o materialmente), el recurso a la medida de seguridad parte de la base de desconocerla a fin de intervenir en su personalidad de manera activa con el mismo fin.

${ }^{138}$ En los hechos ello hace que el origen filantrópico que parece orientar la propuesta se desdibuje por completo perdiendo de paso toda credibilidad. Y es particularmente extraño que en un ámbito donde reinan las referencias al uniformemente aceptado principio del daño a terceros se recurra precisamente a una óptica mucho más discutible y que toma su fuerza argumentativa de la necesidad de dar cobertura a casos que no son de fácil explicación. 


\section{Polit. crim. Vol. 6, No 12 (Diciembre 2011), Art. 5, pp. 387 - 447. [http://www.politicacriminal.cl/Vol_06/n_12/Vol6N12A5.pdf]}

En segundo lugar hay que tener presente que se busca incidir sobre el individuo a objeto de modificar sus patrones de comportamiento a partir de parámetros definidos por el colectivo como expresiones de lo normal, lo moral o lo correcto, mecanismo que abre puertas a la imposición de formas de vida o de conductas representativas de intereses particulares dominantes (perfeccionismo) en los que resulta difícil separar la pretensión de recuperación social del mero adoctrinamiento del individuo. ${ }^{139}$ No se trata de un riesgo teórico pues históricamente este tipo de planteamientos se encuentran estrechamente ligados a dinámicas de imposición de intereses parciales o tiránicos, ${ }^{140}$ al nivel que en la actualidad la sola mención del paternalismo o de la pretensión de corrección del individuo motivan instintivamente una predisposición negativa o de sospecha sobre las reales intenciones que se persiguen. ${ }^{141}$

Por otro lado esta misma dificultad en la determinación los contenidos de referencia abre un riesgo adicional de circularidad, pues entre la definición de lo normal y la afirmación de una incapacidad subsecuente se genera una relación que naturalmente tiende a la autogeneración. Con ello se puede llegar a privar de la capacidad y de la libertad "pura y simplemente en nombre de la negación de la propia libertad" lo que confirma la potencialidad retórica del argumento. ${ }^{142}$

De ahí la vital importancia de arribar a contenidos capaces de superar estas razonables objeciones. Al respecto existe hoy en día un consenso (relativo) en orden a reconocer que ello sucede ante la presencia de déficits de competencias personales fundamentales o "básicas", es decir, en casos en que se pretende reaccionar sobre comportamientos o formas de actuación que resultan indispensables para el desenvolvimiento más elemental del individuo (las necesidades básicas) siendo el único nivel en que se puede sostener que la

\footnotetext{
${ }^{139}$ STRATENWERTH, Derecho Penal, cit. nota ${ }^{\circ}$ 24, pp. 46-7, quien constata este riesgo a pesar de adherir en lo fundamental a esta tesis a efectos de justificar las medidas de seguridad que se imponen sobre inimputables. En España lo constató CASABO RUIZ, "El fundamento”, cit. nota n 71, p. 53

${ }^{140}$ ALEMANY, El concepto, cit. nota ${ }^{\circ} 135$, pp. 13, 33 y ss. DE LUCAS, Javier, "Sobre el origen de la justificación paternalista del poder en la antigüedad clásica”, $D O X A \mathrm{~N}^{\circ} 5$ (1988), p. 243

${ }^{141}$ ALEMANY, El concepto, cit. nota n 135, p. 443; GONZALEZ CONTRÓ, "Paternalismo jurídico", cit. nota $n^{\circ} 132$, p. 104; CAMPS, "Paternalismo y bien común", cit. nota $n^{\circ} 135$, p. 195; GARZON VALDES, “Es éticamente justificable”, cit. nota $n^{\circ} 135$, p. 155. Resulta ilustrativo al respecto el constatar cómo autores estrictamente apegados al utilitarismo y contrarios de lleno a todo tipo de intervenciones "perfeccionistas" e incluso "paternalistas" hayan abierto las puertas a la procedencia de dinámicas de corrección o educación del individuo a propósito de casos que califican como de anormalidad. Baste citar el caso de J.S. Mill quien asume que su conocido planteamiento ("Nadie puede ser obligado justificadamente a realizar o no realizar determinados actos, porque eso fuera mejor para él, porque le hará feliz, porque, en opinión de los demás, hacerlo sería mas acertado o más justo", en On Liberty) es propio de seres y sociedades civilizadas, racionales e ilustradas (DIETERLEN, Paulette, "Paternalismo y estado de bienestar", DOXA N' 5 (1988), p. 179), entendiendo sobre esa base que se puede intervenir sobre personas incultas (carentes de capacidad de juzgar su cultura) y sobre los juicios adelantados que ellas emitan por sobre las reglas de la experiencia (parece que en referencia a los niños, DWORKIN, "El paternalismo", cit. nota $n^{\circ} 135$, p. 153). Más claro queda en cuanto señala que también es legítimo intervenir sobre sociedades primitivas (GARZON VALDES, “Es éticamente justificable", cit. nota $\mathrm{n}^{\circ} 135$, p.167), asumiendo que el despotismo puede en dichos casos 1legar a ser un modo legítimo de gobierno de los bárbaros si se dirige a su mejoramiento (DIETERLEN, "Paternalismo y estado", op. cit., p. 179).

${ }^{142}$ DE FIGUEIREDO DIAS, Direito Penal, cit. nota ${ }^{\circ} 39$, p. 94.
} 


\section{MALDONADO, Francisco. “¿Se puede justificar la aplicación copulativa de penas y medidas de seguridad? Estado actual de las posiciones doctrinales \\ que buscan dicho objetivo".}

intervención es compatible con el respeto a la autonomía del individuo (esto es, que no se opone a la misma). ${ }^{143}$

A partir de ello una primera aproximación parecería que el sistema penal propone valoraciones coincidentes con el objetivo de "recuperación moral del individuo" en tanto los límites que éste plantea para el actuar individual corresponden precisamente a los parámetros elementales de la convivencia. ${ }^{144} \mathrm{El}$ problema que ello propone es que supone una asociación entre delito y comportamiento desviado que resulta desafortunada y cuyos efectos negativos se extreman si pretendemos sobre esa base generar una fuente de incapacitación. En concreto, la ejecución del delito pasaría a constituir una muestra concreta de un actuar incompetente ${ }^{145}$ presupuesto resulta incompatible con la afirmación de la culpabilidad. Dicho concepto supone el reconocimiento de un margen válido de

${ }^{143}$ Esta exigencia restringe las interferencias paternalistas al objetivo de evitar un "daño" concepto difícil de determinar en abstracto y particularmente en nuestro caso. Como referentes se alude a las "necesidades básicas" (ALEMANY, El concepto, cit. nota n 135, pp. 476 y ss.; ATIENZA, Manuel, "Discutamos sobre paternalismo", DOXA N 5 (1988), p. 210; GONZALEZ CONTRÓ, "Paternalismo jurídico", cit. nota n 132, p. 104), a bienes primarios (CAMPS, cit. nota $n^{\circ} 136$, p. 199) o a aspectos que posibilitan la autodeterminación del individuo (NINO, Carlos Santiago, Ética y derechos humanos. Barcelona: Edit. Ariel, 1989, passim). Se ha propuesto complementar dichos criterios con la aceptación o consenso racional (ATIENZA, cit., p. 211; Oo., convincente, en GONZALEZ CONTRÓ, "Paternalismo jurídico", cit. nota n 132, p. 113; parcialmente CAMPS, "Paternalismo y bien común", cit. nota ${ }^{\circ} 135$, p. 225) o recurrir a la ponderación de los intereses comprometidos (DIETERLEN, "Paternalismo y estado", cit. nota n 141, p. 189 en cita a Feinberg, valorado positivamente por ATIENZA, op. cit. p. 210) o al carácter irreversible del daño (DWORKIN, "El paternalismo", cit. nota n ${ }^{\circ}$ 135, pp. 158-9; RAMIRO AVILÉS, "A vueltas", cit. nota n 135, p. 229).

${ }^{144}$ Así ha sucedido materialmente -y con gran éxito- respecto de enajenados, y sobre todo, de menores de edad, justificando sobre sus bases sistemas completos de administración de medidas coactivas (en general, propiamente penales) tendientes a la recuperación o adopción de niveles de socialidad que les permitan disfrutar en plenitud de su personalidad autónoma. Por algo la tendencia a justificar modalidades de control coactivo referidas al delito en el caso de los menores de edad se patentó a partir de conceptos inequívocamente paternalistas ("los salvadores del niño"). Sobre ello vid. GARCÍA MÉNDEZ, Emilio, Infancia. De los derechos a la justicia, $2^{\circ}$ ed., Edit. Del puerto, 2004, pp. 7, 8 y 144 y ss. El mismo concepto subyace, si bien no con atributos justificantes, en la propia idea de "resocialización" y más precisamente en la carencia de condiciones de socialidad que opera como su presupuesto, conceptos recurrentemente citados en el contexto de la intervención penal para caracterizar sus modalidades de intervención (Vid. ZIFFER, Medidas de seguridad, cit. nota $\left.\mathrm{n}^{\circ} 15, \mathrm{p} .70\right)$.

${ }^{145} \mathrm{La}$ incompetencia en el caso de un imputable es asumida como consecuencia propia de un actuar errado, motivado, en este caso, en falta de firmeza en la voluntad. Sin embargo no resulta sencillo determinar en qué consiste dicho error. El argumento parece indicar que éste coincide con la propia decisión de delinquir, debiendo entender que de no verse afectado por la falencia, el sujeto probablemente habría adaptado su comportamiento a las prescripciones normativas. La idea que se expresa al mismo tiempo es que quien delinque en condiciones normales -sin padecer del error- no presenta incompetencia y por ello sólo se hace acreedor de una pena. Si se observa ambos casos tienen en común un acto reprobado. Pero lo desaprobado como anormalidad en este caso debiera ser el hábito, no el delito. Con ello queda en claro que no resulta posible separar ambas hipótesis, a menos que se pueda identificar "otro error" lo que no parece posible. El "riesgo de condena" (el delito sería una muestra de irracionalidad y por ende de un fallo pues expone al individuo a sufrir los efectos de la pena), tampoco puede servir de base para dicha argumentación. No sólo por confirmar lo recién señalado, sino por evidenciar un contrasentido, al habilitar al padecimiento anticipado de una restricción similar a la que se pretendería evitar. En efecto, si el delito es irracional, pues expone al sujeto a una condena que claramente no desea, la medida de seguridad le impedirá incurrir en ese error, a costa de imponerle una restricción de derechos semejante a aquella. 


\section{Polit. crim. Vol. 6, No 12 (Diciembre 2011), Art. 5, pp. 387 - 447. [http://www.politicacriminal.cl/Vol_06/n_12/Vol6N12A5.pdf]}

opciones del individuo entre las que se cuenta la decisión de delinquir, lo que no sólo hace incompatible la actuación paternalista (y la medida de seguridad) y la idea de culpabilidad, sino la propia afirmación de este último juicio de valor. ${ }^{146}$

Ahora bien, en estricto sentido Welzel coloca el acento en un momento previo a la decisión de delinquir, advirtiendo un fallo ético (personal) en supuestos que denotan una tendencia clara al delito. El déficit (de motivabilidad) estaría entonces en la incapacidad del sujeto de llegar a asumir dicha decisión en condiciones que evidencien que se trata de una opción autónoma y plenamente libre, como sucede en aquellos casos en que se acredita una tendencia patológica al delito o un hábito o acostumbramiento a delinquir, supuestos a los que se limitaría en su caso la calificación de la incapacidad. ${ }^{147}$

Más allá de las dificultades que platea el solo hecho de separar estos casos de los espacios legítimos de la decisión individual, ${ }^{148}$ es claro que con ello no se soluciona el problema de la imputación personal, pues sigue presente la contradicción del supuesto de la medida con la afirmación de la culpabilidad. En concreto resulta difícil sostener que el individuo carece de libertad (interna) o de capacidad de autodeterminación moral si el propio Estado reconoce y reafirma dichas cualidades a la hora de afirmar la culpabilidad y de imponerle una pena sobre esa base. ${ }^{149}$ Por el contrario, su reconocimiento lleva a configurar dichos supuestos como casos de inimputabilidad, debiendo por ello renunciarse a la pretensión de imponerles una pena o, alternativamente, reconocer que no concurre el sustrato que habilita a imponer una medida de seguridad. Este argumento fue determinante en el abandono de esta línea argumental, reservándose a partir de ello el análisis de su plausibilidad exclusivamente para los casos de inimputabilidad. ${ }^{150}$

Debemos sin embargo reconocer que esta asentada tendencia no tuvo en cuenta que la mayoría de las intervenciones paternalistas aceptadas o reconocidas en la actualidad no se basan en carencias personales de carácter absoluto sino en actuaciones precisas y determinadas adoptadas por sujetos plenamente libres y considerados responsables a nivel

\footnotetext{
${ }^{146}$ De ahí la asociación entre la idea de comportamiento desviado y los postulados más clásicos de la escuela positiva.

${ }^{147}$ Debemos reconocer que sobre esta base algunos tratamientos de la problemática del paternalismo incluyen como casos de "incompetencia", a dichos efectos, el del "delincuente", junto al niño y al enfermo, englobadas como casos de tendencia o habitualidad. Vid. CAMPS, "Paternalismo y bien común”, cit. nota n 135, p. 197. ${ }^{148}$ Los casos referidos a "debilidad de voluntad" son caracterizados por NINO (Ética y derechos humanos, cit. nota $n^{\circ} 143$, p. 416) como "los mas peligrosos" al ser difícil distinguirlos de una verdadera opción personal diversa a la mayoritaria. Propone como criterio distintivo proceder a verificar si es razonable suponer que en la mayoría de estos casos la conducta tiene al mismo factor generador del riesgo (que se pretende controlar) como fuente u origen. Lo analiza específicamente en torno a las restricciones al consumo del tabaco (p. 433 y ss).

149 ZIFFER, Medidas de seguridad, cit. nota $\mathrm{n}^{\circ} 15$, p. 74

${ }^{150}$ CEREZO MIR (Curso, cit. nota ${ }^{\circ}$ 13, pp. 41-2); FRISCH, "Las medidas de corrección”, cit. nota n 13 , p. 20; GRACIA MARTIN Et. Al., (Sistema de consecuencias, cit. nota $\mathrm{n}^{\circ} 11$, pp. 439 y 440); GUZMAN DALBORA, La pena y la extinción, cit. nota $n^{\circ}$ 4, p. 86; JAKOBS, Derecho Penal, cit. nota $n^{\circ}$ 77, p. 39; ROCA AGAPITO, El sistema de sanciones, cit. nota ${ }^{\circ}$ 85, p. 380; STRATENWERTH, Derecho Penal. cit. nota $\mathrm{n}^{\circ} 24$, p. 43.
} 
MALDONADO, Francisco. “¿Se puede justificar la aplicación copulativa de penas y medidas de seguridad? Estado actual de las posiciones doctrinales

que buscan dicho objetivo".

general. ${ }^{151}$ Se trata en el fondo de casos en que no se entiende comprometida la capacidad general del sujeto y en los que se asume generalmente que hay comunión en los fines últimos que persigue la actuación paternalista con aquellos que "normalmente" elegiría el sujeto, siendo su distanciamiento específico del comportamiento esperado (calificado como racional) lo que legitimaría al Estado para actuar. ${ }^{152}$ Se entiende a partir de esa base que hay una especie de fallo en la voluntad que el individuo pudiere llegar a manifestar externamente (una especie de "error" por desinformación, equívoco circunstancial, inmadurez o falta de firmeza en la voluntad), lo que permite desacreditarla y sustituirla, impidiendo en definitiva que se proceda a la libre elección. El centro del argumento radicaría entonces (en la actualidad) en exigir una opción racional, informada, reflexiva en aquellos ámbitos en que el no hacerlo resultaría altamente perjudicial para el individuo, limitándose con ello las opciones consideradas "competentes".

Esta precisión no ofrece sin embargo un escenario que permita modificar las conclusiones antes esbozadas. Primero, pues no se logra explicar por qué dicho error o falla genera una consecuencia diversa a la imposición de la pena, en cuanto es ésta la reacción que precisamente confirma que dicho comportamiento es desaprobado e intolerado por el ordenamiento en base a razones análogas a las que justifican calificarla como una opción incompetente. $\mathrm{Y}$ en segundo lugar pues este caso no ofrece una caracterización apta para configurar un supuesto de incapacidad que a su vez no incida en el sustento de la capacidad general requerida para imponer una pena. En efecto, y a diferencia de los supuestos en que en la actualidad se reconoce la legitimidad de la intervención paternalista, existe un vínculo directo entre el déficit de voluntad o el error en la decisión que emana de la tendencia o habitualidad delictiva (y en la resolución de llevar una vida al margen de las disposiciones penales vigentes) y la afirmación de la capacidad de culpabilidad, lo que impide sostener la concurrencia conjunta de ambos a la vez.

A lo sumo, y aceptando forzadamente el que ello fuere posible, debiésemos necesariamente concluir que estamos en un escenario similar al que proponen los casos de semiimputabilidad, ${ }^{153}$ pues si entendemos que el déficit señalado no se traduce en una incapacidad general debemos al menos reconocer que debe afectarla de manera parcial. ${ }^{154}$ No se trataría por ello de un escenario apto para justificar un incremento material en la reacción aplicable, pues (con matices) es posible asumir que el contenido de aflictividad

\footnotetext{
${ }^{151}$ Así sucede con las normas que regulan el horario máximo de trabajo o el uso obligatorio del cinturón de seguridad en un vehículo o del casco de protección en motocicletas, las retenciones que prevé el sistema de seguridad social, entre otras.

${ }^{152}$ DIETERLEN, "Paternalismo y estado", cit. nota n ${ }^{\circ}$ 141, p. 182.

${ }^{153}$ Así lo destaca MARIN DE ESPINOZA CEBALLOS, Elena B., La reincidencia: tratamiento dogmático y alternativas político criminales, Granada: Edit. Comares, 1999, p. 173), en cita al planteamiento de Kleinschrod. También aparece claro en CEREZO MIR (Curso, cit. nota $\mathrm{n}^{\circ} 13, \mathrm{p}$. 41): "cuando esta capacidad falta, como en los enfermos mentales, o está considerablemente disminuida como consecuencia de las disposiciones, vicios o hábitos, el sujeto no puede exigir la plena libertad exterior." (El subrayado es nuestro).

${ }^{154}$ Así parece intuirse por Welzel pues en su propuesta se entiende que los "hábitos, malas inclinaciones, vicios o costumbres que los apartan de su respeto" materializarían un fallo ético que incide en la capacidad de desenvolvimiento social del individuo sin llegar a anularla completamente. Lo confirman los énfasis que coloca en sus propios textos al hablar de carencias en la "libertad social completa" o al señalar que dichas personas "carece(n) de la fuerza de voluntad suficiente".
} 


\section{Polit. crim. Vol. 6, № 12 (Diciembre 2011), Art. 5, pp. 387 - 447. [http://www.politicacriminal.cl/Vol_06/n_12/Vol6N12A5.pdf]}

que agregaría la medida de seguridad se vería compensado con una reducción en la pena merecida, justificándose en definitiva una reacción estatal que, en conjunto, resulta equivalente a la que procedería si omitimos los efectos que acarrea la argumentación paternalista. Si bien ello supone igualmente superar la medida de la culpabilidad (reducida por efecto de la incapacidad concurrente) no se logra con ello el efecto de legitimar las reacciones previstas en el ordenamiento positivo para tratar al imputable peligroso, objetivo al cual se asocia esta línea argumental. ${ }^{155}$

Por otro lado, tampoco parece que la doctrina dominante haya aceptado, ni acepte en la actualidad, que la habitualidad o tendencia criminal y el menor efecto inhibitorio o de motivación por las normas que ello supone, deban tener una incidencia atenuante de la capacidad de culpabilidad. ${ }^{156}$ Al contrario, el hecho de que la fuente de la tendencia o hábito delictivo sea atribuible o imputable al propio sujeto que la padece ha sido interpretada históricamente por parte de la doctrina como una razón o un motivo suficiente para desestimar su efecto excusante o atenuante, usando para ello el soporte que concede la lógica de la actio libera in causa. ${ }^{157}$ Es más, se ha llegado a considerar adecuada para

155 Es relevante tener presente que este parece haber sido una de las motivaciones de Welzel cuyo planteamiento se orientó a dejar "tranquilas las conciencias" a la hora de plantearse la inquietud de por qué podemos imponer consecuencias penales que se apartan de la lógica de la culpabilidad por el hecho (un cambio de lectura "en clave moralista").

${ }^{156}$ Este efecto sólo encuentra algún grado de eco en precedentes históricos y parcialmente en la actualidad. Se cita a autores como Buccellati y Kleinschrod -en BERGALLI, Roberto, La recaída en el delito: los modos de reaccionar contra ella, Barcelona, 1980, p. 81; SANCHEZ-TEJERINA, Isaias, Derecho penal español. Tomo I, Introducción y Parte General. $5^{\circ}$ ed. Madrid, 1950, p. 322, quienes sostuvieron en su tiempo que la reincidencia constituía una atenuante de la responsabilidad precisamente en base a una lectura de la peligrosidad referida al hábito. La misma idea se esgrime como argumento en algunas de las posturas denominadas abolicionistas. Así en Groizard (citado en ASUA BATARRITA, Adela, La reincidencia. Su evolución legal, doctrinal y jurisprudencial en los Códigos Penales españoles del siglo XIX, Bilbao: Edit. Universidad de Deusto, 1982, p. 421) o Tissot (p. 127), formando también parte de la crítica que desde el correccionalismo dirige Dorado Montero a la institución (en Psicología Criminal, p. 249). De manera más reciente también puede apreciarse a efectos críticos de la agravación en BAUMANN (citado en MIR PUIG, Santiago, La reincidencia en el Código Penal. Análisis de los arts. 10.14. 10.15, 61.6 y 516.3, Barcelona: Edit., Bosch, 1974, p. 542), BERNHARD, "Reincidencia y medición de la pena" en: SCHÜNEMANN (Coord.), El sistema moderno del Derecho Penal: Cuestiones fundamentales. Estudios en honor de Claus Roxin en su $50^{\circ}$ aniversario (Introducción, traducción y notas de Silva Sánchez), Madrid: edit. Tecnos, 1991 (p. 187) y en España en BACIGALUPO (en Principio de culpabilidad, carácter del autor y poena naturales en el derecho penal actual, en VV.AA.: Teorías actuales en el derecho penal. 75 Aniversario del Código Penal. Buenos Aires, 1998, p. 140 y en "El principio de culpabilidad, e individualización de la pena", en: VVAA: El nuevo Código Penal: Presupuestos y fundamentos. libro Homenaje al Profesor Doctor Don Angel Torio López, Granada: Edit. Comares, 1999, p. 165), MARIN DE ESPINOZA CEBALLOS (La reincidencia, cit. nota ${ }^{\circ} 153$, p. 178), GARZON REAL/MANJON-CABEZA OLMEDA, "Reincidencia y Constitución", Actualidad Penal N¹ (1991), p. 5. Constituyó además un argumento presente en la discusión que motivó el proyecto alternativo alemán de (Vid. BERGALLI, La recaída en el delito, op. cit., p. 81) y que defiende en la actualidad ROXIN ("Qué queda de la culpabilidad", cit. nota $\mathrm{n}^{\circ} 55, \mathrm{p} .676$ ) en su sentido original.

${ }^{157}$ SANCHEZ-TEJERINA (La recaída en el delito, cit. nota $\mathrm{n}^{\circ}$ 156, p. 323) lo refleja con claridad al exponer el argumento de Buccellati y Kleinschrod: "el razonamiento de los que mantienen el criterio de la atenuación cae por su base situando el problema en las acciones liberae in causa: el culpable que no opuso las resistencias debidas al delito la primera vez, y se deja arrastrar posteriormente hacia nuevos delitos, es responsable moralmente. Ya se dijo que la libertad la conquista el hombre con la lucha diaria, oponiendo motivos buenos a los motivos criminales y perversos. La libertad, mas que un acto es un estado. De mantener aquél criterio, el vicioso y el habitual del delito no serían responsables de sus actos". 
MALDONADO, Francisco. “¿Se puede justificar la aplicación copulativa de penas y medidas de seguridad? Estado actual de las posiciones doctrinales

que buscan dicho objetivo".

configurar en concreto una fuente adicional de responsabilidad, que se suma y adiciona sus efectos a la que proviene del delito cometido. ${ }^{158}$ Bajo esta óptica la peligrosidad diagnosticada es entonces un supuesto atribuible al propio infractor, y que aporta un contenido de lesividad que habilita a una mayor intervención. Paradigmático resulta a este respecto el concepto de culpa por la conducción de la vida ${ }^{159}$ y al que el propio Welzel parece adherir a la hora de justificar la ampliación de la pena del reincidente, asumiendo la necesidad de aplicar en estos casos un incremento la pena merecida. ${ }^{160}$

Conviene a este respecto destacar que dichas orientaciones proponen un escenario diverso al sostenido por Welzel pues en ellas el déficit motivacional no constituye el centro del argumento. Lo relevante se ubica en el hecho de que las causas que llevan a configurarlo permiten por sí mismas identificar una fuente de merecimiento alternativa y diversa, radicada en el aporte conciente del propio individuo en su génesis. De ahí que aparezcan preferentemente vinculadas a consecuencias agravatorias de la pena, en cuanto se las considera como parte de los contenidos que pueden ser objeto de una atribución individual.

Pero aun si sostuviéramos que la incapacitación es precisamente la consecuencia merecida que es aplicada como una especie de sanción, con ello no se soluciona el problema de que el presupuesto de intervención no habilita a imponer conjuntamente una pena y una medida, pues la pena aparece desprovista del contenido de la culpabilidad, en tanto anulado por el déficit motivacional que produce el hábito y que sustituye, en los hechos, el contenido que resulta imputado. La óptica del actio libera in causa (que tiene sus propios problemas de legitimación) tampoco resuelve este problema, pues su resultado genera el efecto inverso al dejar sin base a la propia afirmación de la incapacitación. Por ello su efecto directo es precisamente anular el reconocimiento de dicha condición, permitiendo que apliquemos ficticiamente los efectos propios de la plena responsabilidad (se borra artificialmente la falta de capacidad, el hábito, en cuanto resultado atribuible al propio sujeto que lo padece) lo que inevitablemente obliga a asumir un contexto que deja a la medida sin su presupuesto esencial.

\footnotetext{
${ }^{158}$ Resulta interesante destacar como JAKOBS (Derecho Penal, cit. nota ${ }^{\circ} 77$, p. 588) acepta implícitamente el que la disminución de la capacidad de respuesta se puede afirmar en el plano empírico. No obstante entiende que esta cuestión (como toda la que encierra la reincidencia y en general el tratamiento de la habitualidad criminal) se resuelve de forma normativa -como es lógico conforme a los caracteres de su sistematización- en base a la responsabilidad que cabe por el déficit de lealtad al derecho.

${ }^{159}$ Inicialmente este tipo de consideraciones (de autor) llevaron a Mezger a configurar un concepto complejo o combinado de culpabilidad que, sin mucho esfuerzo, termina siendo un juicio al autor y a su personalidad (así MAURACH, Reinhart/GÖSSEL, Karl/ZIPF, Heinz, Derecho Penal. Parte General, (trad. Bofill Genzsch), Tomo II, Buenos Aires: Edit. Astrea, 1995, p. 522; COUSO SALAS, Jaime, Fundamentos del derecho penal de culpabilidad. Historia teoría y metodología, Valencia: Edit. Tirant Lo Blanch, 2006, p. 112). Posteriormente (1938) se independiza el componente temporal configurando la culpa por la conducción de la vida (COUSO SALAS, Fundamentos del derecho penal, op. cit., p. 113), operando ambas modalidades o formas independientes de manera complementaria. A partir de sus Modernas Orientaciones puede apreciarse con claridad el abandono de una culpabilidad compleja para dar paso a una doble modalidad de culpabilidad (pp. 53 y ss. y específicamente pp. 54-5). Vid. MUÑOZ CONDE, Francisco, Edmund Mezger y el derecho Penal de su Tiempo, $4^{\mathrm{a}}$ ed., Valencia: Edit. Tirant Lo Blanch, 2003, pp. 135-7.

${ }^{160}$ WELZEL, Derecho Penal Alemán, cit. nota n 86 , pp. 334-5 y 356. Así lo reconoce también BETTIOL, Guiseppe, Dirito Penale, $12^{\mathrm{a}}$ ed., Padova: CEDAM, 1986 (pp. 577-8).
} 


\section{Polit. crim. Vol. 6, No 12 (Diciembre 2011), Art. 5, pp. 387 - 447. [http://www.politicacriminal.cl/Vol_06/n_12/Vol6N12A5.pdf]}

Se trata además de una tesis que no considera que la contribución a la conformación del hábito ya ha recibido su correspondiente sanción. Es la ejecución del delito precedente lo que motiva el acostumbramiento, cuya ejecución debió motivar su respectiva consecuencia aflictiva. De ahí que una nueva consideración de estos supuestos debiera necesariamente motivar una objeción desde las exigencias del non bis in idem.

Todo ello deja en claro que resulta altamente complejo llegar a compatibilizar pena y media con una base de merecimiento a partir del presupuesto propuesto por Welzel, cualquiera sea la razón de merecimiento posible de identificar en su génesis.

\subsection{La reformulación de Jescheck: la "libertad vinculada a la comunidad".}

\subsubsection{Fórmula propuesta.}

En las últimas décadas Jescheck retoma las orientaciones de Welzel con miras a radicar la justificación de las medidas de seguridad en torno a la libertad del individuo. ${ }^{161}$ Sin embargo evita encontrar su sentido al interior del sujeto -asumiendo que dicha concentración en Welzel es "algo propio de su tiempo"- recurriendo a una especie de colectivización de las nociones propuestas por este autor. En este sentido asume que "la libertad que la Constitución garantiza a todo ciudadano es <una libertad vinculada a la comunidad>". De ahí deduce que "quien no posee la capacidad de desenvolverse en la sociedad sin poner en grave peligro a otros debe tolerar las limitaciones necesarias de su libertad en interés de la seguridad de todos". ${ }^{162}$

Con ello se hacen equivalentes al igual que en Welzel -incluso en forma más clara esta vez- las hipótesis de incapacidad social derivadas de un déficit de desarrollo o del padecimiento de una patología con aquellas en que es mas bien el propio comportamiento del individuo el que ha contribuido -voluntariamente- a apartarlo del margen establecido, situaciones (ambas) que son descritas y caracterizadas como un "fallo ético". El único punto diverso radica en que estos últimos casos son definidos por Welzel como situaciones en que se ha perdido parte del autocontrol en atención a que dicha conducta "antisocial" ha pasado a formar parte de la personalidad del individuo (idea de acostumbramiento) mientras que para Jescheck se trata simplemente de un caso de "abuso de la libertad", situaciones en las que su uso o ejercicio se aparta de la "vinculación a la comunidad" que permite definirla. Sobre esa base Jescheck concluye como algo evidente "que en casos de abuso grave puede ser procedente la privación de derechos que asisten a cualquier persona" afirmación de la que extrae en concreto una "idea de merecimiento." 163

${ }^{161}$ JESCHECK/WEIGEND, Tratado de Derecho Penal, cit. nota n 13, pp. 92:"las medidas de seguridad requieren, al igual que las penas, una justificación: no sólo tienen que ser adecuadas a su fin sino que también deben poder ser sostenidas a la luz de la justicia".

162 JESCHECK/WEIGEND, Tratado de Derecho Penal, cit. nota n 13, p. 92.

${ }^{163}$ Una estructura similar se propone en Gracia Martin, más allá que a fin de cuentas arribe a conclusiones diversas. 
MALDONADO, Francisco. “¿Se puede justificar la aplicación copulativa de penas y medidas de seguridad? Estado actual de las posiciones doctrinales

que buscan dicho objetivo".

\subsubsection{Valoración y crítica.}

Ahora bien, más allá de las cuestiones de fondo, el argumento presenta una primera debilidad de carácter formal. Al delinquir el sujeto ya no se mueve en el marco de la libertad que le corresponde ${ }^{164}$ lo que se encuentra previsto y da lugar a una sanción penal que es la consecuencia precisa de dicho "abuso de la libertad". ${ }^{165}$ Sobre esta base parece evidente que se requiere de algo mas que el abuso (o el mal uso de la libertad) para asumir que se puede y debe ir mas allá, respecto a lo cual la tesis descrita nada aporta. ${ }^{166}$

Además la tesis plantea una definición marcadamente sesgada y dependiente de la libertad que es reconocida a los individuos. No se trata de desconocer que las definiciones que subyacen a la culpabilidad consideran elementos de juicio que resultan del todo ajenos al sujeto, sino de destacar que es completamente diverso entender y reconocer que en su contenido se materializa una síntesis de intereses sociales (a partir de lo cual se hace impensable una noción de culpabilidad desvinculada de la sociedad) a asumir que dicho concepto se encuentra supeditado al interés de la colectividad. En el fondo esta última idea se aproxima bastante a la mera afirmación de una especie de co-responsabilidad social, que equivale en los hechos a una obligación de todo individuo de responder frente a las exigencias de conservación de la colectividad por el sólo hecho de pertenecer a la misma. Dicha estructura (que empalma de manera perfecta con la concepción positivista de las relaciones en comunidad) conlleva en concreto una renuncia a la propia idea de que la culpabilidad constituya una fórmula de imputación o atribución, lo que se demuestra en el hecho de que deja de ser considerada como el parámetro determinante de los espacios de libertad. Dichas orientaciones son precisamente las que se buscaban superar con la referencia a parámetros ético-sociales, cayendo la tesis precisamente en una justificación que en el fondo se muestra idéntica a aquella que pretendía criticar y reemplazar. ${ }^{167}$

\footnotetext{
${ }_{165}^{164}$ FRISCH, "Las medidas de corrección”, cit. nota ${ }^{\circ} 13$, p. 20.

${ }^{165}$ Como indica ROXIN (Derecho Penal, cit. nota $\mathrm{n}^{\circ}$ 13, p. 105) "el argumento del abuso no aclara, sin embargo, la cuestión decisiva de por qué se pierde la libertad más allá de la medida de la propia responsabilidad."

${ }^{166}$ En concreto se echa en falta alguna claridad acerca de cuando podemos afirmar que estamos en presencia de un abuso "grave" de la libertad, lo que se agudiza si tenemos en cuenta que a través de las diversas ediciones de su Tratado, Jescheck no hace sino variar los contenidos esbozados a este respecto sin lograr en el fondo, y por lo mismo, mayores niveles de certeza o claridad. En sus primeras expresiones aparece mezclado con planteamientos referidos a aspectos "internos" y no "sociales" de la libertad (que no se precisan y que de hecho se muestran equívocos si se tiene en cuenta la idea de "vinculación con la comunidad") (Tratado de Derecho Penal, cit. nota $\mathrm{n}^{\circ} 13$, p. 116 y 117). Dichas referencias se suprimen en la $4^{\circ}$ edición del Tratado, siendo reemplazadas por criterios de mera "necesidad social", en un sentido que cuesta apartar de las ideas de defensa o utilidad social (JESCHECK/WEIGEND, Tratado de Derecho Penal, cit. nota n ${ }^{\circ} 13$, p. 92 ) En concreto se señala -sustituyendo íntegramente el párrafo antes transcrito- que: "Decisivo para el mantenimiento de la custodia de seguridad (...) fue últimamente el convencimiento de que no hay un camino más humano para la protección absolutamente necesaria frente a la delincuencia habitual y profesional".

${ }^{167}$ Ello explica que la evolución del criterio decante en una verdadera renuncia al mismo, siendo posible apreciar en Jescheck/Weigend una adhesión expresa, aunque sea parcial, a la idea de la ponderación de intereses y a la necesidad de la medida de seguridad como criterios de justificación, argumentos que -aun inexplicablemente- se exponen en forma paralela a la idea de "libertad asociada a la comunidad".
} 
Lo ratifica el que se trata de un contenido que no se integra a la definición de la culpabilidad (como sucede en la actualidad en torno a las necesidades de la prevención), sino que es utilizado para ir más allá del marco de libertad definido o reconocido a través de dicho concepto. De esta forma la pérdida de libertad que supone la pena, en cuanto fundada en la culpabilidad, se sustituye en caso de la medida de seguridad por el sólo recurso a la necesidad social, con lo cual los fines de protección y cohesión social que pueden predicarse de la intervención penal dejan de legitimarse por el abuso de la libertad reconocida, constituyendo más bien una base que permite llegar a anularla. ${ }^{168}$ De más esta señalar que a partir de esa base los riesgos de abuso son palpables. ${ }^{169}$ Queda por ello la idea de que en estos casos se priva de libertad "pura y simplemente en nombre de la negación de la propia libertad", ${ }^{170}$ cuestión que ya era criticada a Welzel por no precisar los contenidos que le permitían sostener la posibilidad de anular la personalidad de quien era considerado a la vez plenamente culpable.

En lo que si acierta Jescheck es en destacar que tras la pretensión de ir mas allá del marco de la culpabilidad concurre una pérdida del derecho a la libertad que es impuesta como consecuencia o sanción, encontrando la medida de seguridad su apoyo concreto en dicho presupuesto. $^{171}$

\subsection{El ánimo contrario a derecho (Jakobs).}

\subsubsection{Fórmula propuesta.}

La idea del abuso de la libertad que recién hemos comentado también aparece descrita en la formulación que propone Jakobs para justificar la aplicación de un incremento de la reacción procedente en caso de imputables peligrosos. Asume como punto de partida la insuficiencia de los planteamientos centrados en intereses generales pues concibe que se trata de un problema a ser resuelto en una base de méritos o competencias, ${ }^{172}$ debiendo la justificación ser capaz de explicarle al infractor "por qué a él se le priva de la parte más importante de sus derechos que constituyen una persona (...), y no son los otros quienes, a causa de él, tienen que colocarse $<$ chalecos protectores $>$ ". ${ }^{173}$

Reconoce asimismo que la medida de seguridad puede cumplir un papel tutelar o de sanción, configurándose en este último sentido cuando reacciona como respuesta a una atribución. En dicho caso su aporte concreto es reforzar el contenido de seguridad

\footnotetext{
${ }^{168}$ De ahí que Casabó Ruiz asuma que hay también utilitarismo tras la llamada a la reeducación del sujeto cuando lo que se busca es la defensa de la sociedad o de las ideas imperantes en la misma.

$169 \mathrm{Si}$ bien dichas ideas han sido básicamente desarrolladas respecto de inimputables, se ha recurrido, preferentemente en contextos totalitarios como los señalados a la idea de reeducar en términos políticos, cuando el modo de ser no se sujeta a la ideología imperante. CASABO RUIZ ("El fundamento", cit. nota $n^{\circ}$ 71, p. 54).

${ }^{170}$ DE FIGUEIREDO DIAS, Direito Penal. cit. nota ${ }^{\circ}$ 39, p. 94.

${ }^{171}$ FRISCH, "Las medidas de corrección", cit. nota ${ }^{\circ} 13$, p. 20.

${ }^{172}$ A ello contribuye el tajante rechazo de este autor a aceptar que el derecho penal se vincule a lo futuro ("por lo futuro no se puede castigar ya ahora" pues significa pasar "por alto obviamente el principio del hecho", JAKOBS, Derecho Penal, cit. nota ${ }^{\circ} 77$, pp. 77 y 40.

${ }^{173}$ JAKOBS, “Coacción y personalidad", cit. nota ${ }^{\circ} 110$, p. 8, Nota 43.
} 
MALDONADO, Francisco. “¿Se puede justificar la aplicación copulativa de penas y medidas de seguridad? Estado actual de las posiciones doctrinales

que buscan dicho objetivo".

normativo que aporta la pena, función que califica como indispensable, pues el sistema normativo bajo el cual la sociedad se estructura de manera fundamental requiere de un cierto grado de apoyo cognitivo para funcionar y que se define acorde a las necesidades de estabilización (seriedad) de la estructura normativa de soporte. En estos casos es el efecto indiciario de futuro el que impide subsanar el hecho solo en base a la aplicación de una pena, demandando por ello el apoyo cognitivo.

En dicha hipótesis es la vinculación de la medida de seguridad con la autoridad de la norma lo que determina en concreto su extensión. Esta no se rige sólo por el marco de lo merecido (los intereses del autor son menos relevantes mientras mas responsable sea éste de la generación del peligro) ${ }^{174}$ sino también por la necesidad concreta de estabilización. ${ }^{175}$ En síntesis, la medida ha de limitarse a lo necesario para apoyar el efecto de la pena, debiendo por ello cesar una vez que éste se ha logrado. A partir de estas bases sostiene (en torno a la custodia de seguridad) que "quien ha llevado una vida de delincuente habitual se ha merecido la pena privativa de libertad indeterminada" ${ }^{176}$ operando la medida como una respuesta necesaria y merecida. ${ }^{177}$

Dicho planteamiento ha sido profundizado en tiempos recientes por el propio Jakobs en una fórmula que extiende considerablemente sus perspectivas. Toma como premisa el que la sociedad se estructura en base a la presunción de que las personas harán un uso responsable de su libertad. Ello implica que pueden hacerlo en forma acorde a las pautas definidas, como, en su caso, responder de su uso incorrecto. Dicha dinámica (que supone la asunción del contenido de la norma y, en su caso, de la responsabilidad por quebrantarla) es la que genera una base para que opere la seguridad de carácter normativa que proporciona el sistema y que posibilita la convivencia, constituyendo la regla general. ${ }^{178}$ Esta forma de operar es desatendida en aquellos casos en los que no podemos suponer dicha asunción,

${ }^{174}$ JAKOBS, Derecho Penal, cit. nota n ${ }^{\circ} 77, \mathrm{p} .40$.
${ }^{175}$ JAKOBS, Derecho Penal, cit. nota $\mathrm{n}^{\circ} 77, \mathrm{p} .41$.

${ }^{176} \mathrm{La}$ afirmación original la toma de H. Mayer (JAKOBS, Derecho Penal, cit. nota $n^{\circ} 77$, p. 40). Hay que tener presente que Jakobs incluye los casos de autores habituales dentro de su concepto de culpabilidad. Vid. JAKOBS, Derecho Penal, cit. nota ${ }^{\circ} 77$, pp. 587; y en "Culpabilidad y prevención", cit. nota n 31 , pp. 83 y Ss. y 92 y ss.

${ }^{177}$ Con dicho argumento Jakobs busca un límite donde realmente no lo hay, toda vez que lo necesario para que el sistema funcione puede ser más que lo que el propio sistema normativo propone. Y de hecho es así. De ahí que se trate de una base que naturalmente tiende y posibilita una mayor expansión de las medidas de seguridad proponiendo dificultades para compatibilizarla con las exigencias propias de de la interacción normativa. Esta última termina desdibujándose y no solo porque en diversas situaciones la obtención de seguridad cognitiva parece ser más efectiva o funcional, sino también por el solo hecho de asumir que no funciona sin apoyo cognitivo de base. De ahí que se demande una explicación adicional, capaz de justificar la coexistencia de ambas intervenciones (paralelas y diversas) en un orden de prioridad como el sostenido, tarea que Jakobs asume con el tiempo, decantando en una explicación de la función de las medidas de seguridad (particularmente de las aplicables a imputables) bajo los caracteres del llamado "derecho penal del enemigo". Así lo destacan CANCIO MELIÁ, Manuel/FEIJOO SÁNCHEZ, Bernardo, "Estudio Preliminar" en: JAKOBS, Günther, La pena estatal: significado y finalidad, Madrid: Edit. Thomson-Civitas, 2006, pp. 72 y 78; Con mas detalle sobre esta última "evolución" del planteamiento de Jakobs, FEIJOO SÁNCHEZ, Bernardo, Retribución y Prevención general. Un estudio sobre la teoría de la pena y las funciones del Derecho penal, Montevideo-Buenos Aires: Edit. BdeF, 2007, p. 501.

${ }^{178}$ JAKOBS, “Coacción y personalidad”, cit. nota n 110 , p. 3-4. 


\section{Polit. crim. Vol. 6, № 12 (Diciembre 2011), Art. 5, pp. 387 - 447. [http://www.politicacriminal.cl/Vol_06/n_12/Vol6N12A5.pdf]}

pues la ausencia de una predisposición al uso responsable de la libertad hace que la estructura normal deje de funcionar (adecuada o correctamente). Falta en ello la seguridad cognitiva que el sistema requiere como presupuesto operativo.

Esta situación le lleva a concretizar aun más la fuente de merecimiento que antes había descrito asumiendo en la actualidad que "la legitimación de las medidas de seguridad complementarias de pena proviene de un (concreto) defecto personal, causado de manera responsable, de aquél a quien hay que aplicar la medida". Se trata de que "éste no ha cumplido la < prestación debida > consistente en velar por su fiabilidad cognitiva", ${ }^{179}$ lo que no es sino una especie de deber general de comportarse acorde a los mandatos normativos o de mostrar una actitud conforme "al contrato" social.

El fundamento de la aplicación de medidas de seguridad se configuraría entonces en base al quebrantamiento de un deber diverso al que emana de la norma que motiva el delito y de carácter más general, que puede resumirse en la idea de falta de fidelidad al derecho. ${ }^{180} \mathrm{Su}$ incumplimiento es el que habilita a que la sociedad adopte medidas destinadas a compensar la fiabilidad cognitiva faltante, debiendo conseguirla coactivamente.

El nexo con la idea del abuso de la libertad aparece en esta formulación con bastante claridad (y con más de precisión que en Jescheck): Solo los fieles al derecho pueden reclamar el goce de la libertad social completa. El presupuesto del abuso no solo radicaría en este caso en la conducta de vida del infractor sino en la actitud que a través de ella se manifiesta para con el orden social, esto es, en la predisposición al incumplimiento del derecho (ánimo contrario a derecho). Las consecuencias asociadas a este presupuesto también reconocen fuentes similares (llegando incluso a Welzel) toda vez que el efecto directo asociado a su constatación no es otro que la incapacitación (pérdida del derecho a reclamar la libertad) consecuencia que opera como eslabón para habilitar a la imposición de una medida de seguridad. ${ }^{181} \mathrm{Y}$ es que sólo a partir de dicha base resulta posible justificar un tratamiento de mera contención en el que, por definición, se desconoce la condición de sujeto de quien debe padecerlo. ${ }^{182}$ La construcción empalma de manera directa con el

\footnotetext{
${ }^{179}$ JAKOBS, “Coacción y personalidad”, cit. nota $\mathrm{n}^{\circ} 110$, p. 10.

${ }^{180}$ Así se desprende claramente de las palabras de Jakobs: "Si las personas aspiran a la libertad no solamente han de aceptar que (...) deben responder de su comportamiento, sino que más bien tienen que comportarse de tal manera que (...) muestren en conjunto una línea de vida que permitan concluir que serán fieles al Derecho". JAKOBS, “Coacción y personalidad", cit. nota $n^{\circ} 110$, p. 9.

${ }^{181}$ La privación de la condición de sujeto o de persona constituye un elemento que se mueve en el marco de las consecuencias, pues al seleccionar quién es destinatario de esta normativa de excepción (por gravedad, trascendencia o alarma social, etc.), se está definiendo la extensión y destinatarios de la exclusión, con independencia del ánimo presente en quienes deseen apartarse del contrato (CANCIO MELIÁ/FEIJOO SÁNCHEZ, "Estudio Preliminar", cit. nota $\mathrm{n}^{\circ} 177$, p. 65). Dicho contenido se ratifica por el hecho de que al enemigo se le reconoce competencia al momento de identificarlo como tal, debiendo reaccionar el orden social mediante un acto de exclusión. De ahí incluso la necesidad de demonizarlo. Por ello son solo parcialmente correctas las apreciaciones que destacan que las reacciones previstas en este modelo frente al enemigo son medidas de seguridad para imputables peligrosos y no penas, constituyendo una descripción de lo que se propone como tratamiento una vez asentado este marco inicial. En este sentido CANCIO MELIÁ/FEIJOO SÁNCHEZ, "Estudio Preliminar", cit. nota $n^{\circ}$ 177, p. 73.

${ }^{182}$ Esta privación del derecho a la libertad y de la consideración del individuo como persona es reconocida y destacada por el propio Jakobs quien incluso llega a sostener que el "llamar de otra manera a este proceder
} 
MALDONADO, Francisco. “¿Se puede justificar la aplicación copulativa de penas y medidas de seguridad? Estado actual de las posiciones doctrinales

que buscan dicho objetivo".

desarrollo que el mismo Jakobs propone en torno al llamado derecho penal del enemigo ${ }^{183}$ y le permite a Jakobs consolidar una respuesta acertada para el problema que presenta el que la peligrosidad constituya un juicio de futuro y no un hecho atribuible. Si bien la acreditación de un ánimo contrario o infiel al derecho presenta una perspectiva de futuro evidente (no podemos esperar que en lo sucesivo dichos individuos tengan un comportamiento acorde con el derecho) tanto el supuesto de base (patrón de comportamiento que se aparta de manera permanente del orden establecido y una concreta disposición de ánimo regida por dicho objetivo) como el efecto desestabilizador generado (el resultado desvalorado) se constatan en tiempo presente, permitiendo formular por ello un juicio de mérito personal. ${ }^{184}$

Pero lo más relevante es que la identificación de esta animosidad personal le permite a Jakobs abandonar la dependencia que previamente sostuvo entre la medida de seguridad y las necesidades de estabilización normativa, con el consecuente efecto de que la intervención pasa a quedar liberada de cualquier referente limitativo. ${ }^{185}$ En los hechos cualquier exceso por sobre la medida de la pena queda ahora legitimado por la pérdida de la condición de persona. Lo que sucede es que la desestabilización que se imputa al infractor no se encuentra en esta fórmula vinculada a la estructura básica del derecho penal, sino a

sería un eufemismo". JAKOBS, "Coacción y personalidad", cit. nota ${ }^{\circ} 110$, p. 7, nota 43. Asimismo se preocupa de destacar (en La pena estatal: significado y finalidad (trad. y estudio preliminar Cancio Meliá/Feijoo Sánchez), Madrid: Edit. Thomson-Civitas, Madrid, p. 172)) que lo que se busca es precisamente un trato que lo despersonaliza. Desde el punto de vista defendido en el texto es entonces sólo parcialmente correcto asumir que la asunción de la condición de enemigo es un tránsito o proceso paulatino donde es el propio enemigo el que se coloca en condición de tal. Lo cierto es que no solo resulta objetable la posibilidad de autoexcluirse del contrato, sino que además lleva a efectos diversos de los sostenidos en la propuesta, más allá que con dicha actitud (y con dicho efecto) el individuo llegue a ubicarse fuera del Estado. De ser así se reconocería el derecho a no participar y a no someterse al derecho, perdiendo consecuencialmente éste todo su imperio, efectos y el sentido u orientación de sus funciones (Vid. CANCIO MELIÁ, en JAKOBS, Günther/CANCIO MELIÁ, Manuel, El derecho penal del enemigo, Madrid: Edit. Thomson - Civitas, 2003, p. 98).

${ }^{183}$ Sobre esta base llega a sostener que todos aquellos que con su comportamiento habitual o de tendencia se apartan decidida y demostradamente del régimen de sujeción al derecho, renunciando con ello a aportar el mínimo de aseguramiento cognitivo que es necesario, ponen en riesgo la propia mantención del estado de juridicidad. Por ello quien "de una forma presuntamente duradera, ha abandonado el derecho y, por tanto, no garantiza el mínimo cognitivo de seguridad del comportamiento personal y demuestra este déficit a través de su comportamiento", no califica como persona o ciudadano, constiuyendose como enemigo, siendoles exigible una "garantía de no peligrosidad". Vid. JAKOBS, "La autocomprensión de la ciencia del Derecho penal ante los desafíos del presente", en ESER/HASSEMER/BURKHARDT, La ciencia del derecho penal ante el nuevo milenio (trad. MUÑOZ CONDE et al.), Valencia: Edit. Tirant lo Blanch, 2004, pp. 58 y ss.; Vid. Asimismo ROBLES PLANAS, “<Sexual Predators $>$ ", cit. nota ${ }^{\circ} 7$, p. 15 nota 48 en referencia a este planteamiento. El propio Jakobs destaca el nexo en la actualidad ("Coacción y personalidad", cit. nota n ${ }^{\circ} 110$, pp. 7-10 y 2006, pp. 170 y, en general, 167 y ss. DE FIGUEIREDO DIAS (Direito Penal, cit. nota n ${ }^{\circ}$ 39, p. 94) antes ya había asociado ambas construcciones.

${ }^{184}$ Como indica JAKOBS ("La autocomprensión", cit. nota $n^{\circ} 183$, p. 172) "los hechos ulteriores del enemigo se convierten en perturbaciones de un orden" ya en la actualidad.

${ }^{185}$ El riesgo de expansión inherente al argumento es tan claro que el propio Jakobs se ve en la necesidad de advertirlo, si bien lo hace en defensa de la integridad del sistema. Sobre este riesgo de ampliación Vid. SILVA SÁNCHEZ, Jesús María, La expansión del derecho penal. Aspectos de la política criminal en las sociedades postindustriales, Madrid: Edit. Civitas, 2001, pp. 163 y ss.; CANCIO MELIÁ/FEIJOO SÁNCHEZ, "Estudio Preliminar", cit. nota n 177, p. 65 y ss. 


\section{Polit. crim. Vol. 6, № 12 (Diciembre 2011), Art. 5, pp. 387 - 447. [http://www.politicacriminal.cl/Vol_06/n_12/Vol6N12A5.pdf]}

las necesidades autónomas y generales de estabilización del sistema, considerado como un conjunto global. Con ello renuncia también a identificar al enemigo con comportamientos que por si solos provocan niveles importantes de inestabilidad social y estructural por el hecho de afectar un valor esencial nexo que cargaba con buena parte del peso del argumento. Al contrario se concentra más bien en el contenido de inestabilidad que transmite la propia actitud del infractor lo que se refuerza además por el hecho de que en la actualidad este autor refuerza el significado que aportan los componentes empíricos concurrentes. $^{186}$ El efecto directo de todo ello es que se amplían considerablemente las esferas donde es posible reconocer un enemigo. ${ }^{187}$ Lo relevante es que se asume que el solo hecho de la reiteración o la habitualidad delictiva transforma al individuo en enemigo pues se asume que la actitud que ello refleja pone en riesgo todo el funcionamiento del sistema social confiado en la interacción normativa. ${ }^{188}$ Sobre esta base no es extraño que también el ámbito de la criminalidad leve sea vista bajo las mismas perspectivas pues en dichos ámbitos es igualmente posible identificar este efecto de desestabilización generalizada, sea por corresponder a conductas masivas, ${ }^{189}$ por la sola imagen de molestia y desorden (y su potencialidad a efectos de réplica) o lisa y llanamente por que se constata dicha actitud contraria al sistema.

\subsubsection{Valoración y crítica.}

Las dos premisas sobre las que se construye el argumento (ánimo contrario a derecho y el uso de la incapacitación como reacción penal) han motivado numerosas observaciones críticas.

Por un lado son conocidas las objeciones dirigidas a la fórmula del Derecho penal de enemigos. Sin ánimo de repetir el distendido (y casi excesivo) debate del que hemos sido testigos en tiempos recientes sobre el particular ${ }^{190}$, nos conformamos con destacar la dificultad que conlleva llegar a aceptar la sola idea de separar ciudadanos y enemigos, y la despersonalización que se asocia a dicha distinción como decisión pública en el marco de

${ }^{186}$ CANCIO MELIÁ/FEIJOO SÁNCHEZ, “Estudio Preliminar”, cit. nota n ${ }^{\circ}$ 177, p. 60.

${ }^{187} \mathrm{Si}$ se observa con atención poco tienen que ver el comportamiento del delincuente sexual o habitual violento de criminalidad grave o quien reitera en atentados contra la propiedad delincuente de baja monta con un efecto de desestabilización general, y más aun si se los compara con la actividad terrorista, el tráfico de armas o de drogas. El único punto en común es que de todos estos casos se extrae (o afirma) una decisión concreta de apartarse del orden establecido a partir del comportamiento (histórico) del infractor, condición que por ello pasa a ser considerada como argumento suficiente para obligar a una especie de renuncia o privación (forzada) de la pertenencia al contrato social.

${ }^{188}$ A este respecto JAKOBS (“La autocomprensión", cit. nota n 183, p. 179).

${ }^{189}$ Sobre ello, en torno al merecimiento de pena del comportamiento, vid. SILVA SÁNCHEZ, "Delincuencia patrimonial leve", cit. nota $\mathrm{n}^{\circ} 47$, p. 348

${ }^{190}$ La literatura es prácticamente inabarcable. MUÑOZ CONDE, Francisco, De nuevo sobre <el derecho penal del enemigo $>$, Buenos Aires: Edit. Hammurabi, $2^{\text {a }}$ ed. 2007; CANCIO MELIÁ en: JAKOBS/CANCIO MELIÁ, El derecho penal del enemigo, cit. nota $n^{\circ}$ 182; FEIJOO SANCHEZ, Retribución y Prevención general, cit. nota $n^{\circ}$ 177, p. 498; ESER, Albin, “Consideraciones Finales" en: ESER/HASSEMER/BURKHARDT: La ciencia del derecho penal ante el nuevo milenio, cit. nota $\mathrm{n}^{\circ} 183$, pp. 471 y 472 . Un panorama completo en CANCIO MELIÁ/GOMEZ JARA-DIEZ (coords.), Derecho penal del enemigo. El discurso penal de la exclusión, ed. BdF, 2006, donde se recopilan en dos volúmenes un conjunto de trabajos centrados en el tratamiento de las cuestiones que motiva dicho concepto. Vid. asimismo Sección de Crónicas de $R P \mathrm{n}^{\mathrm{o}} 18$ (2006). 
MALDONADO, Francisco. “¿Se puede justificar la aplicación copulativa de penas y medidas de seguridad? Estado actual de las posiciones doctrinales

que buscan dicho objetivo".

un Estado de Derecho. ${ }^{191}$ La sola idea de identificar ámbitos donde es posible suprimir el reconocimiento de la personalidad (que es el centro de la propuesta) ha motivado necesariamente una valoración crítica ya desde el orden constitucional ${ }^{192}$ y un déficit de legitimación que incluso ha hecho dudosa su calificación como sistema propio del ámbito del "derecho". ${ }^{193}$ Conviene tener en cuenta que mucho antes que se aceptara con carácter mas general (al menos en el entorno occidental) la necesidad de proscribir el recurso a la pena de muerte se había ya desterrado del desarrollo en comunidad la opción de considerar la imposición de una muerte civil, ${ }^{194}$ tanto desde una perspectiva liberal (con base en la igualdad de todos los integrantes de la comunidad) como desde el asentamiento de un contenido material de democracia participativa. ${ }^{195}$ En el ámbito penal, además, la idea de que asiste un derecho o una perspectiva legítima dirigida a la reinserción (al menos como expectativa siempre vigente de reincorporación a la sociedad libre) lo refleja con claridad. Finalmente, constituye asimismo una opción inconveniente desde la propia perspectiva que propone una marcada concentración en las necesidades de funcionamiento del sistema penal. ${ }^{196}$

Conviene también recordar que la idea de recurrir a la incapacitación en el ámbito penal (directa o indirectamente) no es para nada nueva y no ha dado precisamente gratos recuerdos. Destaca el claro ejemplo que proporciona el régimen nacionalsocialista alemán ${ }^{197}$ y el amplio campo de excesos llevados a cabo en nombre de la óptica tutelar en

${ }^{191}$ Constituye una distinción que ni siquiera es aceptable en el plano de la mera descripción. Al respecto CANCIO MELIÁ/FEIJOO SÁNCHEZ, "Estudio Preliminar", cit. nota n 177, pp. 63, 74 y 81.

${ }^{192}$ Por todos MUÑOZ CONDE, Edmund Mezger, cit. nota n ${ }^{\circ} 160$, p. 75$)$.

${ }_{193}^{193}$ CANCIO MELIÁ en: JAKOBS/CANCIO MELIÁ, El derecho penal del enemigo, cit. nota n ${ }^{\circ} 182$, p. 99.

${ }^{194}$ ZAFFARONI/ALAGIA/SLOKAR, Derecho Penal. Parte General, Buenos Aires: Edit. Ediar, $2^{\circ}$ ed., 2002, p. 937. Probablemente Jakobs no estará de acuerdo con esta afirmación. De hecho sostiene que "la despersonalización (...) se produce de modo puntual, exclusivamente en lo que se refiere al posible uso de la libertad. Por lo demás, la personalidad jurídica queda incólume; en un ejemplo, el delincuente a asegurar mantiene su derecho a su integridad corporal, a su propiedad y debe pagar impuestos". El autor parece tras ello olvidar el conjunto de espacios y derechos que entran dentro de la supresión que conlleva la calificación de enemigo (garantías procesales, penales, etc.), incluyendo en un lugar especial a la culpabilidad, por su significado. No es de extrañar que sobre esta base las regulaciones prevean consecuencias que a poco andar priven al individuo de algo más que la libertad ambulatoria (véase al respecto LOPEZ PEREGRIN, "¿Lucha contra la criminalidad", cit. nota $\mathrm{n}^{\circ}$ 91, p.13). Lo cierto es que la tesis sirve para justificar cualquier cosa.

${ }^{195}$ Vid BUSTOS, Juan/HORMAZABAL, Hernán, Lecciones de Derecho Penal, Madrid: Edit. Trotta, 1999, p. 65 .

${ }^{196}$ Como indica Cancio Meliá:“(...) si es cierto que la característica especial de las conductas frente a las que existe o se reclama <derecho penal del enemigo> está en que se afectan a elementos de especial vulnerabilidad en la identidad social, la respuesta jurídico-penalmente funcional no puede estar en el cambio de paradigma que supone el derecho penal del enemigo, sino que, precisamente, la respuesta idónea en el plano simbólico al cuestionamiento de una norma especial debe estar en la manifestación de normalidad, en la negación de la excepcionalidad, es decir, en la reacción conforme a los criterios de proporcionalidad y de imputación que están en la base del sistema jurídico-penal <normal $>$. Así se niega al infractor la capacidad de cuestionar, precisamente, esos elementos esenciales amenazados.”. CANCIO MELIÁ (en JAKOBS/ CANCIO MELIÁ, El derecho penal del enemigo, cit. nota n 182), pp. 97 y 98 y nota 68.

${ }^{197}$ La idea de estratificación o categorización de sujetos, en base a diferencias en su valoración intrínseca, en este caso fundada en motivaciones raciales derivadas de afirmaciones pseudo-científicas, llevó incluso a proponer medidas de intervención biológica como la esterilización. Al respecto MUÑOZ CONDE, Francisco, "La esterilización de los asociales en el nacionalsocialismo ¿un paso para la solución final de la <cuestión 


\section{Polit. crim. Vol. 6, № 12 (Diciembre 2011), Art. 5, pp. 387 - 447. [http://www.politicacriminal.cl/Vol_06/n_12/Vol6N12A5.pdf]}

para el tratamiento de las infracciones penales de menores de edad. ${ }^{198}$ También se refleja en las permanentes pretensiones de usar el sistema penal para imponer valores o formas de ser (propias de un conjunto o incluso de la mayoría, pero no de todos) sea mediante el expediente de recurrir a la perversión moral como actitud sancionable (sanción de conductas consideradas inmorales o sin víctima) ${ }^{199}$ o mediante la atribución directa de incapacidad (usando la idea de corrección que subyace a la medida de seguridad en base supuestos que se definen en base a actitudes o comportamientos que ni siquiera requiere llegar a configurarse como tipos de autor). ${ }^{200}$

Por otro lado, ya advertimos que la idea de recurrir al ánimo contrario a derecho no es algo novedoso en Derecho penal, ni ha contado tampoco con buena acogida. ${ }^{201}$ Se trata de una

social>”, Revista electrónica de Ciencia penal y Criminología $\mathrm{N}^{\circ} 4 \quad(2002), \quad$ en http://criminet.ugr.es/recpc/recpc_04-05.html, [Última visita 08.06.11].

${ }^{198}$ Por todos GARCÍA MÉNDEZ, Infancia, cit. nota ${ }^{\circ} 144$, pp. 7 y ss.

${ }^{199}$ En estos casos no se le reconoce al individuo la opción de llevar a cabo el comportamiento en cuanto delictivo (los planes de vida o decisiones autónomas pueden limitarse por el interés social) pasando a formar parte de las áreas vedadas a la interacción, cobrando aun mas sentido en torno a la calificación del delito como desviación (la idea de incapacidad, en su caso, sólo encontraría sustento en la propia opción - culpablede delinquir). Sobre ello Vid. DE FIGUEIREDO DIAS, Direito Penal, cit. nota n ${ }^{\circ} 39$, p. 94 . Muñoz Conde lo destaca en relación a las nuevas figuras penales y modificaciones introducidas en 2003 en España en materia de regulación de la libertad sexual, particularmente aplicado a la sanción de los delitos vinculados a pornografía en base a la utilización de imágenes virtuales sin base real o en la sanción del proxeneta (en "La generalización del derecho penal de excepción: tendencias legislativas y doctrinales. Entre la Tolerancia Cero y el derecho penal del enemigo", en VV.AA.: "La generalización del derecho penal de excepción: tendencias legislativas". CGPJ- $C D J \mathrm{n}^{\circ} 128$ (2007), pp. 20 a 22). En el mismo sentido SANCHEZ GARCÍA DE PAZ, "Alternativas al Derecho Penal", cit. nota n ${ }^{\circ}$, pp. 887-9.

${ }^{200}$ Véase asimismo, en torno al caso español, la referencia hecha por Gracia Martin a la "Ley de represión de la masonería y el comunismo", promulgada en España en 1941 (en: "Consideraciones Críticas sobre el actualmente denominado <derecho penal del enemigo>", Revista Electrónica de Ciencia penal y Criminología, CRIMINET, p. 4, en: http://criminet.ugr.es/recpc/07/recpc07.html, [Última visita 08.06.11].

${ }^{201}$ En su tiempo Manzini vio tras la recaída en el delito una "voluntad persistente de delinquir" o de "no uniformarse al orden jurídico penal" asumiendo que dicha base lesiona "el interés genérico de mantenimiento del orden jurídico general protegido penalmente" (MIR PUIG, La reincidencia, cit. nota $\mathrm{n}^{\circ}$ 156, p. 442). Dicho concepto aparece asociado directamente a un "derecho general de seguridad de todo ciudadano" que lleva a afirmar un mayor grado de daño social. Se trata en el fondo de un combate a la desobediencia que toma en cuenta el pernicioso ejemplo y la minimización del respeto a la autoridad que propone el comportamiento del reincidente (MARTINEZ DE ZAMORA, Antonio, La Reincidencia, Ed. universidad de Murcia, 1971, p. 53); También en Ranieri, (RANIERI, Silvio, "Manual de derecho penal", Tomo II, Parte General, Versión castellana de la $4^{\mathrm{a}}$ edición (revisada y corregida de 1968) de Jorge Guerrero, Bogotá: Edit. Temis, 1975, p. 202 y, en general, pp. 196 y ss.) se aprecia disposición de ánimo que permite situar la voluntad del individuo en una condición de contradicción con el ordenamiento proscribiéndose directamente el grado de rebelión al derecho. Latagliata (LATAGLIATA, Angelo Raffaele, Contibuto allo Studio Della Recidiva, Publicaciones de la Facultad de Derecho Universidad de Nápoles, Nápoles, 1958, p. 83) ve una base para agravar la reacción en lo que considera es una "actitud opuesta al arrepentimiento", empalmando con la "mayor" rebeldía (a la ya manifestada con el delito se suma aquella que evidencia la falta de arrepentimiento); Maurach entendió que la advertencia de la condena se produce cuando la recaída puede ser entendida como expresión de una rebeldía especialmente intensa frente al orden social, esto es, en la contumacia en la enemistad con el derecho (implícito en MAURACH, Reinhart, Tratado de derecho Penal (trad. y notas Juan Córdoba Roda), Barcelona: Edit. Ariel, 1962, p. 145 y luego expreso en la 4a ed. -referencia tomada de MIR PUIG, La reincidencia, cit. nota $\mathrm{n}^{\circ}$ 156, pp. 500-1). En la actualidad también Cerezo Mir lo considera como uno de los elementos que agregan un mayor desvalor a la reincidencia. Se refiere en concreto a una actitud de 
MALDONADO, Francisco. “¿Se puede justificar la aplicación copulativa de penas y medidas de seguridad? Estado actual de las posiciones doctrinales

que buscan dicho objetivo".

base coincidente con las posiciones que desde antiguo han pretendido ver una especie de deber genérico en todos los individuos asociado a la eventualidad de recaída en el delito. ${ }^{202}$ Se vincula en concreto a la necesidad de que el Estado garantice niveles de seguridad, conceda estabilidad, integridad colectiva o que procure la preservación del orden jurídico o de la autoridad de las normas, intereses genéricos (todos ellos) que pasan a ser considerados como bienes o valores directamente dignos y necesitados de protección (a pesar de su abstracción) y que se estiman lesionados con el comportamiento rebelde.

En el derecho de habla hispana el ejemplo mas cercano se grafica en la tesis defendida por Mir Puig acerca del fundamento de la reincidencia, donde se ocupa de identificar una base análoga (rebeldía, la enemistad con el derecho o animo contrario a bienes o el orden jurídico). ${ }^{203}$ Sin embargo este mismo autor se encarga en paralelo de ocupar la misma base para descartar que sea una argumento suficiente para legitimar la intervención penal (sea fundacional o agravatoria) ${ }^{204} \mathrm{El}$ centro de dicha conclusión se basa en los defectos que este acercamiento plantea en materia de lesividad, ${ }^{205}$ pues no solo es evidente la dificultad de identificar un contenido lesivo diverso del propio interés general de prevención del delito (o de intereses genéricos carentes de concreción como el orden social), sino también es tremendamente complejo llegar a identificar tras ello una prohibición concreta diversa y autónoma respecto a la que subyace a cada norma penal. ${ }^{206} 207$

rebeldía frente a las exigencias del ordenamiento jurídico, es decir, una disposición de ánimo hostil al derecho (CEREZO MIR, Curso de Derecho penal, cit. nota $\mathrm{n}^{\circ} 13$, p. 169)

${ }^{202}$ Originalmente dichas pretensiones se vincularon a la idea de alarma social, destacando la presencia de un daño político (inestabilidad) adicional al propio y específico del delito. Lo destaca Zaffaroni (ZAFFARONI/ALAGIA/SLOKAR, Derecho Penal, cit. nota $n^{\circ}$ 194, p. 1009) quien a partir de ello establece precisamente un nexo con planteamientos de base funcionalista (tributarias de la idea de estabilidad normativa), clarificando que se trata de un mismo contenido de lesión lo que es propio del desvalor penal. Y es que nadie podría hoy en día discutir que tras toda tipificación se agrega al contenido disvalioso del bien jurídico lesionado, un contenido de interés social. En su tiempo lo vio claro Manzini al dividir el contenido mediato e inmediato de cada lesión (Vid. MARTINEZ DE ZAMORA, La Reincidencia, cit. nota ${ }^{\circ}$ 201, p. 51).

${ }^{203}$ MIR PUIG, La reincidencia, cit. nota $n^{\circ} 156$, pp. 527-8.

${ }^{204}$ Mir Puig entiende que el efecto agravatorio solo puede radicar en la lesión de un injusto adicional que es lo que serviría de base a la imposición de una mayor pena. De ahí que se trate de una doble infracción (en los hechos, un concurso) que lleva a la agravación. Vid. MIR PUIG, La reincidencia, cit. nota ${ }^{\circ}$ 156, pp. 529 y ss.

${ }^{205}$ Según MIR PUIG (La reincidencia, cit. nota $\mathrm{n}^{\circ}$ 156, pp. 539-40) el fundamento descrito parece satisfacer las exigencias del desvalor del acto pero carece de un referente concreto en materia de resultado (jurídico), esto es, carece de lesividad (En el mismo sentido CEREZO MIR, Curso de Derecho Penal, cit. nota ${ }^{\circ} 13$, p. 168 y ALONSO ALAMO, Mercedes, El sistema de las circunstancias del delito, Universidad de Valladolid, 1981, p. 673) por lo cual el hecho de fundar una intervención penal sobre dicho supuesto importa desplegar una actuación de carácter moralizante, en cuanto carece de un concreto objeto de tutela.

${ }^{206}$ En su tiempo hay quienes buscaron dicho referente en una obligación de no adquirir (el hábito o la tendencia al delito) pretendiendo de esta forma sortear las objeciones a la agravación que veían un déficit de culpabilidad por el acostumbramiento. Principalmente Bettiol desarrolló una hipótesis de culpa por la conducción de la vida en base a la secuencia de vida generadora de la inclinación (BETTIOL, Dirito Penale, cit. nota $\mathrm{n}^{\circ}$ 161, pp. 438-9). En España Pacheco habló del hábito en formación (PACHECO, Joaquín Francisco, El Código Penal Concordado y Comentado, Estudio preliminar y anotaciones de TÉLLEZ AGUILERA, Madrid: Abel. Edisofer, 2000, p. 252) y en la actualidad ZUGALDÍA (Derecho penal, cit. nota $\left.\mathrm{n}^{\circ} 36, \mathrm{p} .895\right)$ destaca la posible iniciación al hábito de cometer delitos como el único fundamento de base 


\section{Polit. crim. Vol. 6, No 12 (Diciembre 2011), Art. 5, pp. 387 - 447. [http://www.politicacriminal.cl/Vol_06/n_12/Vol6N12A5.pdf]}

Lo cierto es que dicha disposición de ánimo no logra aportar un contenido diverso al que proporciona su perspectiva de futuro, constituyendo por ello una fórmula representativa de un índice de peligrosidad (o un supuesto para llegar a afirmarla, según se prefiera), ${ }^{208}$ debiendo por ello ser tratada acorde a su contenido real a riesgo de caer en un nuevo eufemismo. $^{209}$

\section{Síntesis.}

Realizada esta revisión parece claro que el panorama que ofrece la búsqueda de una justificación para el tratamiento asegurativo del imputable peligroso es poco alentador. Con ello, también queda en evidencia que en el conjunto de opiniones que abogan por su legitimidad las diferencias son las que parecen primar.

De esta forma todo indica que debiésemos arribar a una conclusión tendiente a desechar la opción dualista o, mejor dicho, la posibilidad de sostener la legitimidad de llegar a superar la medida de la culpabilidad por razones de peligrosidad. Ello pues la ausencia de una justificación ad-hoc se debiera traducir en una renuncia a la intervención que precisamente carece de dicho fundamento.

No obstante no creemos que sean menores las dificultades que encierra el monismo de ejecución, en tanto sus presupuestos resultan igualmente afectados por la interacción que supone el dualismo, presentando por ello contradicciones o falencias no menos relevantes. El desafío por ello apunta a profundizar en la síntesis que configura al modelo. De ello ya habrá tiempo de ocuparse en otro lugar.

predicable de la reincidencia si bien a efectos de fundar una objeción de legitimidad. La proximidad con el contenido de la "garantía de no peligrosidad" (acreditar una línea de vida que permitan concluir que serán fieles al Derecho") es evidente, mas allá de que esta última tiene incluso un carácter mas general.

${ }^{207}$ Si bien también se le ha reconocido a dicho elemento un papel agravatorio de la culpabilidad (ALONSO ALAMO, El sistema, cit. nota $\mathrm{n}^{\circ}$ 205, p. 673) se trata de un planteamiento difícil de sostener en una configuración de corte preventivo. De hecho, el propio Jakobs lo utiliza como argumento para ir más allá de la culpabilidad lo que es del todo incompatible con la opción de asumir que la incrementa. Finalmente, conviene también destacar que la identificación de rebelión y culpabilidad tampoco es nueva, constituyendo perspectivas superadas, al menos a nivel formal. Vid. SILVA SÁNCHEZ, Aproximación al Derecho penal contemporáneo, Barcelona: Edit. J.M. Bosch Editor, Reimpresión, 2002, p. 409 y Nota 421.

${ }^{208}$ Esta equiparación puede advertirse claramente en quienes, como MUÑOZ CONDE/GARCÍA ARAN (Derecho Penal, cit. nota $\mathrm{n}^{\circ} 36$, p. 488), especifican que el presupuesto de la reincidencia radica en "lo recalcitrante de la actitud del sujeto que insiste en la desobediencia a las normas penales".

209 Ello explica que en definitiva MIR PUIG (La reincidencia, cit. nota $\mathrm{n}^{\circ} 156$, pág. 584) proponga igualmente considerar la aplicación de medidas de seguridad a partir del mismo supuesto, mas allá que en su concepto dicha valoración se vincule más estrechamente a la reiteración y la rebeldía a la presencia de una condena previa. 
MALDONADO, Francisco. “¿Se puede justificar la aplicación copulativa de penas y medidas de seguridad? Estado actual de las posiciones doctrinales

que buscan dicho objetivo".

\section{BIBLIOGRAFÍA}

ALEMANY, Gregorio, El concepto y la justificación del paternalismo, Edición digital de Alicante, Biblioteca Virtual Miguel de Cervantes, 2005 (http://www.cervantesvirtual.com/).

ALONSO ALAMO, Mercedes, El sistema de las circunstancias del delito, Universidad de Valladolid, 1981.

ANDRES DOMÍNGUEZ, Ana Cristina, "Habituales y Reincidentes", Revista de Derecho Penal n²2 (2007), pp. 69-91.

ASUA BATARRITA, Adela, La reincidencia. Su evolución legal, doctrinal y jurisprudencial en los Códigos Penales españoles del siglo XIX, Bilbao: Edit. Universidad de Deusto, 1982.

ATIENZA, Manuel, "Discutamos sobre paternalismo", DOXA № 5 (1988), pp. 203 a 214.

AVILÉS, Ramiro, “A vueltas con el paternalismo jurídico”, Revista Derechos y Libertades $\mathrm{N}^{\circ} 15$, Época II (Junio 2006), pp. 211 a 256.

BACIGALUPO ZAPATER, Enrique, "Principio de culpabilidad e individualización de la pena", en VV.AA,: El nuevo Código Penal: Presupuestos y fundamentos. libro Homenaje al Profesor Doctor Don Angel Torío López, Granada: Edit. Comares, 1999 , pp. 33 a 48.

, "Principio de culpabilidad, carácter del autor y poena naturales en el derecho penal actual", en VV.AA., Teorías actuales en el derecho penal. 75 Aniversario del Código Penal. Buenos Aires, 1998, pp. 131 a 152.

BARBERO SANTOS, Marino, Marginación social y Derecho represivo, Barcelona: Bosch, 1980.

BERGALLI, Roberto, La recaída en el delito: los modos de reaccionar contra ella, Barcelona, 1980.

BERISTAIN, Antonio, Medidas penales en derecho contemporáneo. Teoría, legislación positiva y realización práctica, Madrid: Edit. Reus, 1974.

BETTIOL, Guiseppe, Dirito Penale, 12a ed., Padova: CEDAM, 1986.

BOTTOMS, Roger/BROWNSWORD, A.E., "The dangerousness debate after the Floud Report", British Journal of criminology (Julio 1982), pp. 229 y ss.

BUSTOS, Juan/HORMAZABAL, Hernán, Lecciones de Derecho Penal, Madrid: Edit. Trotta, 1999.

CAMPS, Victoria, "Paternalismo y bien común", DOXA N 5 (1988), pp. 195 a 202.

CANCIO MELIÁ, Manuel/FEIJOO SANCHEZ, Bernardo, "Estudio Preliminar" en: JAKOBS, Günther, La pena estatal: significado y finalidad, Madrid: Edit. ThomsonCivitas, 2006.

CANCIO MELIÁ, Manuel, "Derecho penal del enemigo" en JAKOBS, Günther/CANCIO MELIÁ, Manuel, Derecho penal del enemigo, Madrid: Edit. Thomson-Civitas, 2003.

CANO PAÑOS, Miguel Angel, El marco jurídico y criminológico de la custodia de seguridad en el Derecho penal alemán, $C P C \mathrm{~N}^{\circ} 91$ (2007), pp. 205-250 
Polit. crim. Vol. 6, No 12 (Diciembre 2011), Art. 5, pp. 387 - 447.

[http://www.politicacriminal.cl/Vol_06/n_12/Vol6N12A5.pdf]

CASABO RUIZ, José Ramón, "El fundamento de las medidas de seguridad", en VV.AA.: Peligrosidad social y medidas de seguridad. La ley de peligrosidad y rehabilitación social de 4 de Agosto de 1970, Colección de Estudios, Universidad de Valencia, 1974, pp. 37 a 59.

"Actualidad del pensamiento histórico sobre la legislación penal preventiva", en VV.AA.: Peligrosidad social y medidas de seguridad. La ley de peligrosidad y rehabilitación social de 4 de Agosto de 1970, Colección de Estudios, Universidad de Valencia, 1974, pp. 61 a 89.

CASTIÑEIRA PALOU, María Teresa/RAGUÉS I VALLÈS, Ramón, "Three Strikes. El principio de proporcionalidad en la jurisprudencia del Tribunal Supremo de los Estados Unidos", $R D P C, 2^{\circ}$ epoca, $\mathrm{N}^{\circ} 14$ (2004), pp. 59 a 85.

CEREZO MIR, José, "Medidas de seguridad aplicables a las personas exentas de responsabilidad penal por padecer una anomalía o alteración psíquica", en: VV.AA., Homenaje al Dr. Marino Barbero Santos. In Memoriam, Ediciones Universidad Castilla-La Mancha / Cuenca: Ediciones Universidad Salamanca, 2001, pp. 927 a 933.

, "El Tratamiento de los delincuentes habituales en el borrador de anteproyecto de código penal, parte general", en: VV.AA., Política criminal y reforma penal. Libro homenaje al profesor Del Rosal, Madrid, 1993, pp. 249 a 255.

, Curso de derecho Penal español. Parte General, Introducción. $6^{\text {a }}$ Ed., Madrid: Edit. Tecnos, 2004.

CURY URZÚA, Enrique, Derecho Penal. Parte General, $7^{\text {a }}$ Edición, Santiago: Ediciones Universidad Católica de Chile, 2005.

CHOCLAN MONTALVO, José Antonio, Las medidas de seguridad y corrección en el nuevo Código penal, Poder Judicial No 43-44 (1996), pp. 85 y ss.

COUSO SALAS, Jaime, Fundamentos del derecho penal de culpabilidad. Historia teoría y metodología, Valencia: Edit. Tirant Lo Blanch, 2006.

DE FIGUEIREDO DIAS, Jorge, Direito Penal. Parte Geral, Brasil: Coimbra Editora, 2004.

DE LA CUESTA ARZAMENDI, José Luis, “¿Justificación de la tortura ? Insuficiencia de la normativa penal internacional", en: DE LA CUESTA ARZAMENDI/DENDALUZE/ECHEBURÚA (Comps.), Criminología y Derecho Penal al servicio de la persona. Libro-Homenaje al Profesor Antonio Beristain, Donosita-San Sebastián: Instituto Vasco de Criminología, 1989, pp. 695 y ss.

DE LA CUESTA AGUADO, Paz María, Culpabilidad. Exigibilidad y razones para la exculpación, Universidad de Cádiz, Edit. Dykinson, 2004.

DE LUCAS, Javier, "Sobre el origen de la justificación paternalista del poder en la antigüedad clásica", DOXA N 5 (1988), pp. 243 a 249.

DIAZ MAROTO, Julio, "Las Medidas de Seguridad y corrección”, $A P \mathrm{~N}^{\circ} 36$ (1991).

DIETERLEN, Paulette, "Paternalismo y estado de bienestar", DOXA N 5 (1988), pp. 175 a 194.

DWORKIN, Gerald, "El paternalismo", en: BETEGON/DE PARAMO (Dirs.), Derecho y Moral. Ensayos analíticos, Barcelona: Edit. Ariel, 1990.

ESER, Albin, "Consideraciones Finales", en: ESER/HASSEMER/BURKHARDT: La ciencia del derecho penal ante el nuevo milenio (trad. Muñoz Conde et al.), Valencia: Edit. Tirant lo Blanch, 2004, pp. 463 y ss. 
MALDONADO, Francisco. “¿Se puede justificar la aplicación copulativa de penas y medidas de seguridad? Estado actual de las posiciones doctrinales

que buscan dicho objetivo".

ETCHEBERRY O., Alfredo, Derecho Penal. Parte General, $3^{\text {a }}$ Edición, Santiago: Edit. Jurídica de Chile, 2004.

FALCONE, Diego, "Una mirada crítica a la regulación de las medidas de seguridad en Chile", Revista de Derecho de la Pontificia Universidad Católica de Valparaíso XXIX (2007), pp. 235 a 256.

FRISCH, Wolfgang, "Las medidas de corrección y seguridad en el sistema de consecuencias jurídicas del derecho penal. Clasificación en las teorías de la pena, configuración material y exigencias del Estado de Derecho" (trad. Patricia Ziffer ), In Dret 3(2007).

GARCÍA ARAN, Mercedes, Fundamentos y aplicación de penas y medidas en el Código Penal de 1995, Pamplona: Edit. Aranzadi, 1997.

GARCÍA MENDEZ, Emilio, Infancia. De los derechos a la justicia, $2^{\circ}$ ed., Edit. del Puerto, 2004.

GARCÍA-PABLOS DE MOLINA, Antonio, Derecho Penal. Introducción, Servicio de Publicaciones Facultad de Derecho. Universidad complutense de Madrid.

GARZON REAL/MANJON-CABEZA OLMEDA, "Reincidencia y Constitución”, AP N¹ (1991), pp. 1 a 13

GARZON VALDÉS, Ernesto, “¿Es éticamente justificable el paternalismo jurídico?”, $D O X A \mathrm{~N}^{\circ} 5$ (1988), pp. 155 a 174.

GARRIDO MONTT, Mario, Derecho Penal. Parte General, (T. I y II), Santiago: Edit. Jurídica de Chile, $4^{\circ}$ ed., 2007.

GIMBERNAT ORDEIG, Enrique, “¿Tiene un futuro la dogmática jurídico-penal?”, en, DEL MISMO, Estudios de Derecho Penal, Madrid: Edit. Tecnos, $3^{\mathrm{a}}$ ed., 1990, pp. 140 a 161.

, "El sistema del derecho penal en la actualidad" en, DEL MISMO, Estudios de Derecho Penal, Madrid: Edit. Tecnos, $3^{\mathrm{a}}$ ed., 1990, pp. 162 y ss.

GONZÁLEZ CONTRÓ, "Paternalismo jurídico y derechos del niño", Isonomía $\mathrm{N}^{\circ} 25$ (2006), pp. 101 a 135.

GRACIA MARTIN, Luis, "Sobre la legitimidad de medidas de seguridad contra delincuentes imputables peligrosos en el Estado de Derecho" en: VV.AA., Estudios penales en Homenaje a Enrique Gimbernat, Tomo I, Madrdi: Ed. Edisofer, 2008, pp. 975 y ss.

, Culpabilidad y prevención en la moderna reforma penal española, $A P \mathrm{~N}^{\circ} 37$ (1993), pp. 547 y ss.

GRACIA MARTIN/BOLDOVA PASAMAR/ALASTUEY DOBON, Tratado de las consecuencias jurídicas del delito, Valencia: Edit. Tirant lo Blanch, 2006.

GUZMAN DALBORA, José Luis, La pena y la extinción de la responsabilidad penal, Montevideo/Buenos Aires: Edit. BdeF, 2009.

HAFFKE, Bernhard, "Reincidencia y medición de la pena" en: SCHÜNEMANN (Coord.), El sistema moderno del Derecho Penal: Cuestiones fundamentales. Estudios en honor de Claus Roxin en su $50^{\circ}$ aniversario" (Introducción, traducción y notas de Silva Sánchez), Madrid: edit. Tecnos, 1991, pp. 179 a 195. 
Polit. crim. Vol. 6, № 12 (Diciembre 2011), Art. 5, pp. 387 - 447.

[http://www.politicacriminal.cl/Vol_06/n_12/Vol6N12A5.pdf]

HASSEMER, Winfried, "Argomentzione con concetti fondamentalli. L'esempio della dignitá umana", Ars Interpretandi, Annuario di ermeneutica giuridica $\mathrm{n}^{\circ} 10$ (Valore, Principi e Regole) (2005), Milán.

HASSEMER, Winfried/MUÑOZ CONDE, Francisco, Introducción a la criminología y al derecho penal, Valencia: Edit. Tirant lo Blanch, 1989.

JAKOBS, Günther, "Coacción y personalidad. Reflexiones sobre una teoría de las medidas de seguridad complementarias a la pena", InDret $\mathrm{N}^{\circ} 1$ (2009).

, La pena estatal: significado y finalidad (Trad. y estudio preliminar Cancio Meliá/Feijoo Sánchez), Madrid: Edit. Thomson-Civitas, 2006.

, Derecho Penal. Parte General. Fundamentos y Teoría de la Imputación, $2^{\mathrm{a}}$ Edición corregida, (Traducción de Cuello Contreras, J. y Serrano González, J.L.), Madrid: Edit. Marcial Pons, 1997.

JAKOBS, Günther/CANCIO MELIÁ, Manuel, El derecho penal del enemigo, Madrid: Edit. Thomson - Civitas, 2003.

JAEN VALLEJO, Manuel, Sistema de consecuencias jurídicas del delito, nuevas perspectivas, Instituto de Investigaciones jurídicas, Universidad nacional Autónoma de Mexico, 2002.

JESCHECK, Hans Heinrich, Tratado de Derecho Penal. Parte general, (trad. Manzanares Samaniego), $4^{\mathrm{a}}$ ed., Granada: Edit. Comares, 1993.

JESCHECK, Hans Heinrich/WEIGEND, Thomas, Tratado de Derecho Penal. Parte general, (trad. Olmedo Cardenete), $5^{\mathrm{a}}$ ed. renovada y ampliada, Granada: Edit. Comares, 2002.

JORGE BARREIRO, Agustín, "Reflexiones sobre la compatibilidad de la regulación de las medidas de seguridad en el Código Penal de 1995 con las exigencias del Estado de Derecho", en: VV.AA., Homenaje al Profesor Dr. Gonzalo Rodriguez Mourullo", Navarra: Edit. Thomson Civitas, 2005, pp. 565 a 586.

, "Crisis actual del dualismo en el estado social y democrático de derecho", en: Modernas tendencias en la ciencia del derecho penal y en la criminología, UNED (actas y congresos ), Madrid, 2001, pp. 143 y ss.

, "Las medidas de seguridad en la reforma penal española", en: VV.AA., Politica criminal y reforma penal. Libro homenaje al profesor Del Rosal, Madrid, 1993, pp. 725 y ss.

Civitas S.A., 1976.

, Las medidas de seguridad en el derecho español, Madrid: Edit.

LANDROVE DIAZ, Gerardo, "La reforma de las medidas de seguridad", en La Ley, 29 de Marzo de 2004.

, Las consecuencias jurídicas del delito, 5a ed., Edit. Tecnos, 2002.

LASCURAIN SANCHEZ, Juan Antonio, "Por un derecho penal solo penal: derecho penal, derecho de medidas de seguridad y derecho administrativo sancionador", en: VV.AA., Homenaje al profesor Dr. Gonzalo Rodríguez Mourullo, Navarra: Edit. Thomson Civitas, 2005, pp. 587 y ss.

LATAGLIATA, Angelo Raffaele, Contibuto allo Studio Della Recidiva, Napolés: Publicaciones de la Facultad de Derecho Universidad de Nápoles, 1958.

LEAL MEDINA, Julio, La historia de las medidas de seguridad: de las instituciones preventivas más remotas a los criterios científicos modernos, Navarra: edit. Thomson-Aranzadi, Cizur-menor, 2006. 
MALDONADO, Francisco. “¿Se puede justificar la aplicación copulativa de penas y medidas de seguridad? Estado actual de las posiciones doctrinales

que buscan dicho objetivo".

, La problemática existente para la aplicación de y ejecución de las medidas de seguridad, Universidad Complutense de Madrid, 1999 (Recurso electrónico).

LISZT, Franz Von, La idea de fin en el Derecho Penal, ed. conjunta de Universidad Nacional Autónoma de México - Universidad de Valparaíso Chile, Edeval, 1994.

LOPEZ PEREGIRN, Carmen, “¿Lucha contra la criminalidad mediante el cumplimiento íntegro y efectivo de las penas?”, Revista Española de Investigación Criminológica REIC AC-02-03, en: http://www.criminologia.net

LOPEZ-REY ARROJO, Manuel, "Algunas reflexiones sobre el peligro de la noción de peligrosidad", $C P C \mathrm{~N}^{\circ} 19$ (1983), pp. 19 a 26.

MARIN DE ESPINOZA CEBALLOS, Elena B., La reincidencia: tratamiento dogmático y alternativas político criminales, Granada: Edit. Comares, 1999.

MARTINEZ DE ZAMORA, Antonio, "La Reincidencia", Ed. universidad de Murcia, 1971

MARTINEZ GUERRA, AMPARO, Nuevas tendencias político criminales en la función de las Medidas de seguridad. Su repercusión en la legislación española, Madrid: Edit. Dykinson, 2004.

MAURACH, Reinhart, Tratado de derecho Penal, (trad. y notas Juan Córdoba Roda) Barcelona: Edit. Ariel, 1962.

MAURACH, Reinhart/ZIPF, Heinz, Derecho Penal. Parte General, (trad. Bofill Genzsch), Tomo I, Buenos Aires: Edit. Astrea, 1995.

MAURACH, Reinhart/GÖSSEL, Karl Heinz/ZIPF, Heinz, Derecho Penal. Parte General, (trad. Bofill Genzsch), Tomo II, Buenos Aires: Edit. Astrea, 1995.

MIR PUIG, SANTIAGO, Derecho Penal. Parte General, Barcelona: Edit. Reppertor, $7^{\mathrm{a}}$ Ed., 2005.

, La reincidencia en el Código Penal. Análisis de los arts. 10.14. 10.15, 61.6 y 516.3, Barcelona: Edit. Bosch, 1974.

MUÑOZ CONDE, Francisco, "La generalización del derecho penal de excepción: tendencias legislativas y doctrinales. Entre la Tolerancia Cero y el derecho penal del enemigo", en: VV.AA., "La generalización del derecho penal de excepción: tendencias legislativas". CGPJ-CDJ n 128 (2007), pp. 9 y ss.

, De nuevo sobre <el derecho penal del enemigo>, Buenos Aires: Edit.

Hammurabi, 2005.

, Derecho Penal y Control Social, reimpresión de la $2^{\mathrm{a}}$ Edición, Colección Monografías Jurídicas N 98, Bogotá: Edit. Temis, 2004.

, Edmund Mezger y el derecho Penal de su Tiempo, $4^{\mathrm{a}}$ ed., Valencia:

Edit. Tirant Lo Blanch, 2003.

, "Las medidas de seguridad: eficacia y ámbito de aplicación ante la jurisprudencia del Tribunal Constitucional”, La Ley, 1991-3, pp. 827 y ss.

, "Monismo y dualismo en el derecho penal Español", Estudios Penales y Criminológicos VI (1983), Universidad Santiago de Compostela, pp. 215 y ss.

MUÑOZ CONDE, Francisco/GARCÍA ARAN, Mercedes, Derecho Penal. Parte General, $8^{\mathrm{a}}$ ed., Valencia: Edit. Tirant Lo Blanch, 2010.

NAUCKE, Wolfgang, Derecho Penal. Una introducción. $\left(10^{\mathrm{a}}\right.$ ed. traducida por Leonardo Brond), Buenos Aires: Edit. Astrea, 2006.

NINO, Carlos Santiago, Etica y derechos humanos. Barcelona: Edit. Ariel. 1989. 
Polit. crim. Vol. 6, № 12 (Diciembre 2011), Art. 5, pp. 387 - 447.

[http://www.politicacriminal.cl/Vol_06/n_12/Vol6N12A5.pdf]

NOVOA MONREAL, Eduardo, Curso de Derecho Penal chileno, $3^{\mathrm{a}}$ Ed., Santiago: Edit. Jurídica de Chile, 2005.

OCTAVIO DE TOLEDO Y UBIETO, Emilio, "Las medidas de seguridad con arreglo al Código Penal: carácter, presupuesto y límites”, Poder Judicial N60 (2000), pp. 107 y ss.

, Sobre el concepto de derecho penal, Madrid: Sección de publicaciones, Facultad de Derecho, Universidad de Madrid, 1981.

OLESA MUÑIDO, Francisco Felipe, Las Medidas de Seguridad, Barcelona: Edit. Bosch, 1951.

PACHECO, Joaquín Francisco, El Código Penal Concordado y Comentado, Estudio preliminar y anotaciones de TÉLLEZ AGULLERA. Madrid: Abel. Edisofer, 2000.

PIÑA ROCHEFORT, Juan Ignacio, Derecho penal. Fundamentos de la responsabilidad, Santiago: Edit. AbeledoPerrot, 2010.

QUINTERO OLIVARES, Gonzalo, "Reflexiones sobre el monismo y el dualismo ante el proyecto de Código Penal", en: La reforma penal y penitenciaria, Santiago de Compostela, 1980, pp. 571 y ss.

, Manual de Derecho Penal. Parte General, $3^{\text {a }}$ ed., Pamplona:

Edit. Thomson / Aranzadi, 2002.

RANIERI, Silvio, Manual de derecho penal, Tomo II, Parte General, Versión castellana de la $4^{\mathrm{a}}$ edición (revisada y corregida de 1968) de Jorge Guerrero. Bogotá: Edit. Temis, 1975.

ROBLES PLANAS, Ricardo, " $<$ Sexual Predators $>$. Estrategias y límites del derecho penal de a peligrosidad", InDret 4 (2007).

ROCA AGAPITO, Luis, El sistema de sanciones en el Derecho Penal español, Barcelona: Edit. Bosch, 2007

RODRIGUEZ MOURULLO, Gonzalo, "Medidas de seguridad y Estado de derecho", en: VV.AA., Peligrosidad social y medidas de seguridad. La ley de peligrosidad y rehabilitación social de 4 de Agosto de 1970, Colección de Estudios, Universidad de Valencia, 1974, pp. 343 a 372.

, "Significado político y fundamento ético de la pena y la medida de seguridad", Revista General de Legislación y Jurisprudencia (1965), pp. 759 y ss.

ROMEO CASABONA, Carlos Maria, Peligrosidad y derecho penal preventivo, Barcelona: Edit. Bosch, 1986.

ROXIN, Claus, "Franz von Liszt y la concepción político-criminal del Proyecto Alternativo", en: DEL MISMO, Fundamentos Político-criminales del Derecho Penal, Buenos Aires: edit. Hammurabi, 2008.

, “'Tiene futuro el derecho penal?”, PJ N 49 (1998), pp. 373 y ss.

, Derecho Penal. Parte General. Tomo I. Fundamentos. La estructura de la Teoría del delito. Trad. Luzón-Peña, D.M., Diaz y García Conlledo, M., De Vicente Remesal, J., Madrid: Edit. Civitas, 1997. 692.

, "Que queda de la culpabilidad en Derecho penal", $C P C \mathrm{~N}^{\circ} 30$ (1986), pp. 671 a

, Política criminal y sistema del Derecho penal, (trad. Muñoz Conde), Barcelona: Edit. Bosch., 1972. 
MALDONADO, Francisco. “¿Se puede justificar la aplicación copulativa de penas y medidas de seguridad? Estado actual de las posiciones doctrinales

que buscan dicho objetivo".

SANCHEZ GARCÍA DE PAZ, Isabel, "Alternativas al Derecho Penal del enemigo desde el derecho Penal del ciudadano" en: CANCIO MELIÁ/GÓMEZ-JARA DIEZ (Coords.), Derecho penal del enemigo. El discurso penal de la exclusión, Vol. 2, Madrid: Edit. Thomson-Civitas, 2006, pp. 845 y ss.

SANCHEZ LÁZARO, Fernando Guanarteme, "Un problema de peligrosidad post delictual. Reflexiones sobre las posibilidades y límites de la denominada custodia de seguridad", $R P \mathrm{~N}^{\circ} 17$ (2006), pp. 142 a 162.

SANZ MORAN, Angel, "El tratamiento del delincuente habitual", Política Criminal no 4 (2007), pp. 1-16 (http://www.políticacriminal.cl)

, "De nuevo sobre el tratamiento del delincuente habitual peligroso", en: VV.AA., Derecho penal y criminología como fundamento de la política criminal: estudios en homenaje al profesor Alfonso Serrano Gómez, Madrid: Edit. Dykinson, 2006, pp. 1085 a 1101.

, "Sobre la justificación de las Medidas de Corrección y seguridad", en: JORGE BARREIRO (edit.), Homenaje al profesor dr. Gonzalo Rodríguez Mourullo, Madrid: edit. Thomson / Aranzadi, 2005, pp. 969 y ss.

, Las medidas de corrección y seguridad en el Derecho Penal, Valladolid:

Edit. Lex Nova, 2003.

SCHÜNEMANN, Bernd, "La función del principio de culpabilidad en el derecho penal preventivo", en: DEL MISMO (Coord.), El sistema moderno del Derecho Penal: Cuestiones fundamentales. Estudios en honor de Claus Roxin en su $50^{\circ}$ aniversario (Introducción, traducción y notas de Silva Sánchez), Madrid: edit. Tecnos, 1991, pp. 147 a 178.

SILVA SÁNCHEZ, Jesús María, “Peligrosidad.”, InDret 4 (2007).

, "Delincuencia patrimonial leve: una observación del estado de la cuestión”, EPC, Vol. XXV (2005), Santiago de Compostela, pp. 333 a 360; También publicado en VV.AA., Dogmática y Criminología. Dos visiones complementarias del fenómeno delictivo. Homenaje a Alfonso Reyes Echandía, Bogotá: Edit. Legis, 2005, pp. 567 y ss.

“Medidas de seguridad sin imputación personal subjetiva? Consecuencias de la incidencia de anomalías y alteraciones psíquicas en niveles sistemáticos distintos de la imputabilidad", en: LOPEZ BARJA DE QUIROGA/ZUGALDIA ESPINAR (Coord.), Dogmática y Ley penal. Libro Homenaje a Enrique Bacigalupo, Madrid-Barcelona: Edit. Marcial Pons, 2004, pp. 867 a 890.

, "El retorno a la inocuización. El caso de las reacciones jurídicopenales frente a los delincuentes sexuales violentos", en: VV.AA., Homenaje al Dr. Marino Barbero Santos. In Memoriam, Ediciones Universidad Castilla-La Mancha/ Cuenca: Ediciones Universidad Salamanca, 2001, pp. 699 a 710.

, La expansión del derecho penal. Aspectos de la política criminal en las sociedades postindustriales, Madrid: Edit. Civitas, 2001.

, "Consideraciones sobre las medidas de seguridad a propósito de su regulación en el nuevo Código Penal Español”, en: DEL MISMO, Perspectivas sobre la política criminal moderna, Biblioteca de Estudios Penales Universidad Austral, Buenos Aires: Editorial Abaco de Rodolfo Desalma, 1998, pp. 59 a 103. 
Polit. crim. Vol. 6, No 12 (Diciembre 2011), Art. 5, pp. 387 - 447.

[http://www.politicacriminal.cl/Vol_06/n_12/Vol6N12A5.pdf]

, "La regulación de las medidas de seguridad (artículo 6)", en: DEL MISMO, El Nuevo Código Penal: Cinco cuestiones fundamentales, Barcelona: Edit. Bosch, 1997.

, "Consideraciones sobre las medidas de seguridad para inimputables y semiimputables (con especial referencia al PCP 1994)", en: VV.AA., Estudios Jurídicos en Honor del Profesor Dr. D. José Ramón Casabó Ruiz, T.II., Valencia: Universitat de Valencia, Institut de Criminología, 1997, pp. 789 y ss.

SILVA SÁNCHEZ/FELIP I SABORIT/ROBLES PLANAS/PASTOR MUÑOZ, "La ideología de la seguridad en la legislación penal española presente y futura”, en: DA AGRA/DOMÍNGUEZ,/GARCÍA AMADO/HEBBERECHT/RECASEN (Eds.), La seguridad en la sociedad del riesgo. Un debate abierto. Barcelona: Edit. Atelier, 2003.

STRATENWERTH, Günther, Derecho Penal. Parte General I. El hecho punible (Trad. Cancio Meliá/Sancinetti ), Navarra: Edit. Thomson Civitas, 2005.

URRELA MORA, Asier, "Los principios informadores del derecho de medidas en el Código penal de 1995", RDPC, 2 época, N 8 (2001), pp. 167 a 194.

VON HIRSCH, Andrew, "La prolongación de la pena para los delincuentes peligrosos", en: CID/LARRAURI (Eds.), La delincuencia violenta: ¿Prevenir, castigar o rehabilitar ?, Valencia: edit. Tirant lo Blanch, 2005, pp. 191 a 210.

WELZEL, Hans, Derecho Penal Alemán. Parte General, 11ª Ed., (Trad. Bustos/Yañez), Santiago: edit. Jurídica de Chile.

ZAFFARONI, Eugenio Raúl/ALIAGA, Alejandro/SLOKAR, Alejandro, Derecho Penal. Parte General, $2^{\circ}$ ed., Buenos Aires: Edit. Ediar, 2002.

ZIFFER, Patricia, Medidas de seguridad. Pronósticos de peligrosidad en derecho penal, Buenos Aires: Edit. Hammurabi, 2008.

ZUGALDIA ESPINAR, José Miguel, Fundamentos de Derecho penal. Parte general, Edit. Valencia: Tirant Lo Blanch, 1993.

2004.

, Derecho penal. Parte general, Valencia: Edit. Tirant lo Blanch, 